\title{
BIOMOC, A Multispecies Solute-Transport Model with Biodegradation
}

By Hedeff I. Essaid and Barbara A. Bekins

U.S. GEOLOGICAL SURVEY

Water-Resources Investigations Report 97-4022

Menlo Park, CA 1997

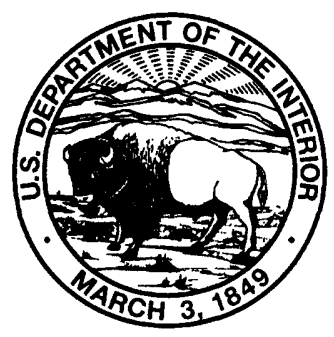




\section{U.S. DEPARTMENT OF THE INTERIOR \\ BRUCE BABBITT, Secretary}

\section{U.S. GEOLOGICAL SURVEY}

Gordon P. Eaton, Director

The use of firm, trade, and brand names in this report is for identification purposes only and does not constitute endorsement by the U.S. Geological Survey.

For additional information write to:

Regional Hydrologist

U.S. Geological Survey

Water Resources Division

345 Middlefield Rd.

Menlo Park, CA 94025
Copies of this report can be purchased from:

U.S. Geological Survey

Information Services

Box 25286

Federal Center

Denver, CO 80225 


\section{PREFACE}

This model, BIOMOC, was developed through modifications of an existing transport model (MOC), that was developed originally by Konikow and Bredehoeft (1978). We recommend that this documentation be used in conjunction with the documentation of Konikow and Bredehoeft (1978). Although extensive testing of BIOMOC indicates that this model will yield reliable results for a variety of problems, the user is cautioned that the accuracy and efficiency of the model can be affected significantly for certain combinations of parameter values and boundary conditions. Further discussion of these issues may be found in the Stability Criteria section.

The code and documentation for this model is available for downloading over the Internet from a USGS software repository. The repository is accessible on the World Wide Web (WWW) at http:// h2o.usgs.gov/software/. The code may also be obtained via anonymous FTP from the /pub/software directory on the Water Resources Information server (h2o.usgs.gov or 130.11.50.175). Future revisions and updates of the code will be made available for downloading form these same sites.

Acknowledgments. The authors appreciate the helpful model evaluation and review comments provided by USGS colleagues L. F. Konikow, M. A. Scholl, and E. Warren. Funding for this work was provided in part by US EPA Interagency Grant \#DW14936020-01-3 and by the USGS Toxics Substances Hydrology Program. 


\section{CONTENTS}

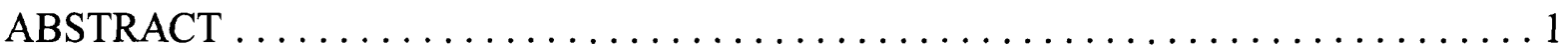

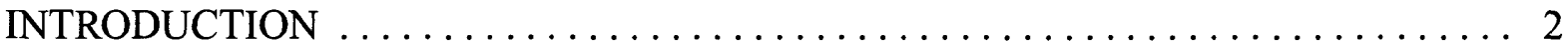

THEORETICAL BACKGROUND AND GOVERNING EQUATIONS. . . . . . . . . 2

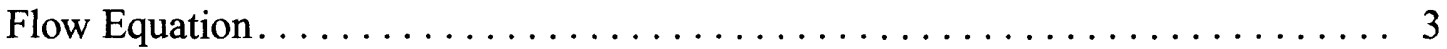

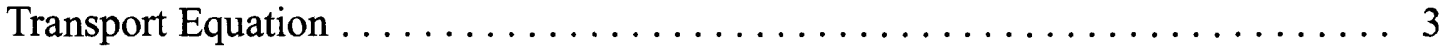

Biodegradation Terms.............................. 3

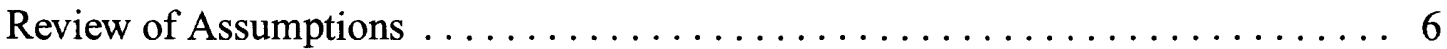

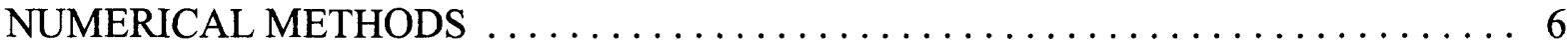

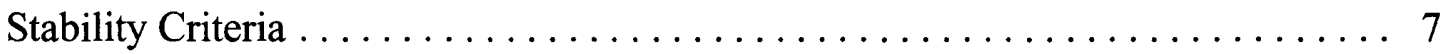

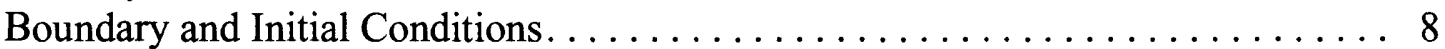

Mass Balance ..................................... 10

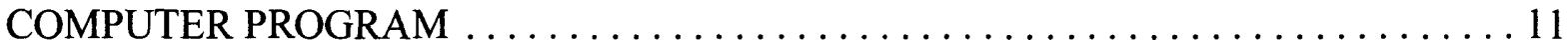

General Program Features. . . . . . . . . . . . . . . . . . . . . . 11

Setting Dimensions . . . . . . . . . . . . . . . . . . . . . . . . 12

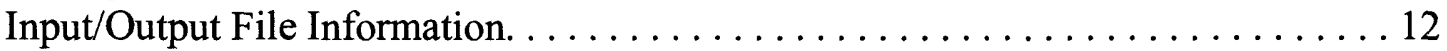

MODEL EVALUATION .................................... 14

One-Dimensional Transport with Linear Sorption, Decay, and

Biodegradation ................................... 14

Aerobic Biodegradation and Transport of Toluene and Benzene........... 21

Aerobic Biodegradation and Denitrification of a Substrate with Cellular

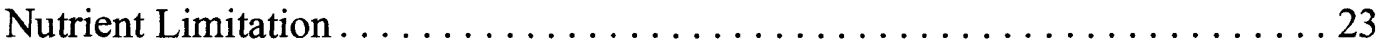

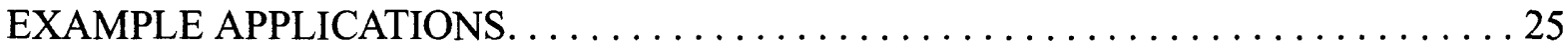

Application to Chlorinated Solvents........................ 26

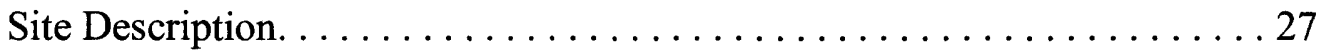

The Conceptual Model ............................. 28

Model Parameter Estimates .......................... 29

Flow and transport parameters ...................... 29

Biodegradation kinetics parameters . . . . . . . . . . . . . . 29

Uptake coefficients ............................ 30

Model Results .................................. 30

Simulation of the Bemidji, Minnesota Crude-Oil Spill Site. . . . . . . . . . . 33

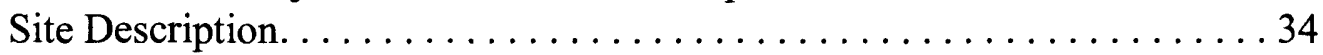

The Conceptual Model ............................... 35

Model Parameter Estimates ........................... 38

Flow and transport parameters $\ldots \ldots \ldots \ldots \ldots \ldots \ldots \ldots \ldots \ldots \ldots \ldots$

Biodegradation kinetics parameters $\ldots \ldots \ldots \ldots \ldots \ldots \ldots \ldots \ldots \ldots \ldots$

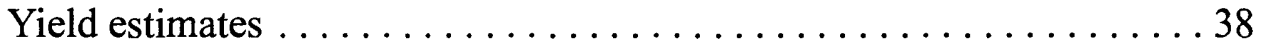

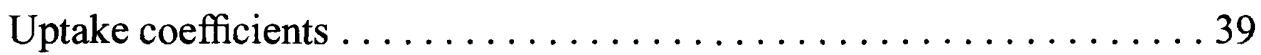

Initial biomass estimates......................... 39

Calibrated Model Results . . . . . . . . . . . . . . . . . . . . . . . 39

CONCLUSIONS. ...................................... 42

REFERENCES ..................................... 43

APPENDIX A: NOTATION . . . . . . . . . . . . . . . . . . . . 47 
APPENDIX B: DEFINITION OF SELECTED PROGRAM VARIABLES . . . . . . . . . 49

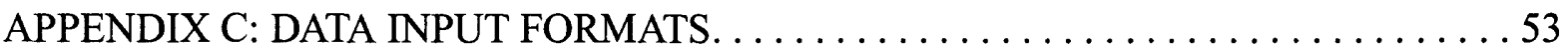

APPENDIX D: INPUT DATA FOR TEST PROBLEM. . . $\ldots \ldots \ldots \ldots \ldots \ldots \ldots 60$

APPENDIX E: OUTPUT FOR TEST PROBLEM $\ldots \ldots \ldots \ldots \ldots \ldots \ldots \ldots \ldots \ldots \ldots \ldots \ldots$

\section{ILLUSTRATIONS}

Figure 1. Plots showing effect of time step size on biodegradation term accuracy . . . 8

2. Geometry of (a) a two-dimensional areal simulation and (b) a vertical cross-section simulation illustrating the input parameters that must be specified for each case ...................... 9

3. Comparison of analytical (lines) and numerical (points) solutions for transient zero-order decay $(+)$, first-order decay $(\diamond)$, first-order decay of dissolved phase with retardation $(\Delta)$, and first-order decay of dissolved and sorbed phase with retardation $(\mathrm{X}) \ldots \ldots \ldots \ldots \ldots \ldots \ldots \ldots \ldots \ldots$

4. Comparison of analytical (lines) and numerical (points) solutions for steady state zero-order decay $(\Delta)$ and first-order decay $(\vartheta) \ldots \ldots \ldots 19$

5. Comparison of analytical (lines) and numerical (points) solutions for steady state Monod kinetics ..................... 20

6. Experimental and simulation results of Chen and others (1992) and BIOMOC results for aerobic degradation of toluene and benzene .... 22

7. Simulation results obtained using BIOMOC (lines) and the model of Kindred and Celia (1989) (symbols) for aerobic degradation and nitrate reduction with cellular nutrient limitation . . . . . . . . . . . 25

8. Comparison of modeled and observed concentrations of chlorinated aliphatics and other compounds along a simulated flowline at Dover AFB. The observed values are averages over four years . . . . . . . 27

9. The simulated two-dimensional cross section at the Bemidji, Minnesota, site, showing the recharge zones used in the model simulation (table 12), the discrete representation of the oil body, and the geochemical zones of the ground-water plume (modified from Baedecker and others

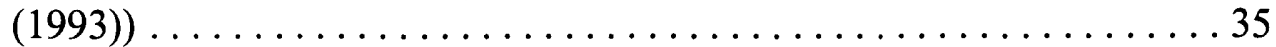

10. Changes in simulated (lines) and observed (symbols) concentrations with time at a location $36 \mathrm{~m}$ downgradient from the center of the oil body: (a) volatile and nonvolatile dissolved organic carbon (VDOC and NVDOC, respectively); (b) dissolved manganese $\left(\mathrm{Mn}^{2+}\right)$ and dissolved iron $\left(\mathrm{Fe}^{2+}\right)$; (c) dissolved oxygen (DO) and methane; and (d) nitrogen, aerobes, $\mathrm{Mn} / \mathrm{Fe}$ reducers, and methanogens $\ldots \ldots \ldots \ldots \ldots \ldots \ldots$ 


\section{TABLES}

Table 1. List of BIOMOC subroutines ......................... 11

2. Example DIMS.INC file used for setting problem dimensions ........ 13

3. Parameters used in transient zero-order decay, first-order decay, and firstorder decay with sorption simulations $\ldots \ldots \ldots \ldots \ldots \ldots \ldots \ldots \ldots$

4. Parameters used in steady state zero-order decay and first-order decay simulations ................................ 19

5. Parameters used in steady state Monod kinetics simulation..........20

6. Parameters used in the simulation of aerobic degradation of toluene and

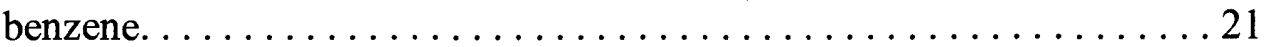

7. Parameters used in the simulation of aerobic degradation and denitrification with cellular nutrient limitation .............. 24

8. Uptake coefficients used in the chlorinated solvent example ......... 31

9. Model parameters used in the chlorinated solvent example .......... 32

10. Biodegradation model parameters, and their description, from the BIOMOC input file for the chlorinated solvent example ......... 33

11. Biodegradation processes, the solutes involved in each process, and the microbial population responsible for each process in the Bemidji

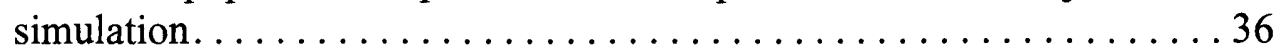

12. Initial and recharge water concentration in milligrams per liter for the Bemidji, Minn., example ......................... 37

13. Biodegradation parameters used in the Bemidji, Minn., simulation. . . . . . 40

14. Biodegradation parameters, and their description, from the BIOMOC input file for the Bemidji, Minn., simulation $\ldots \ldots \ldots \ldots \ldots \ldots \ldots \ldots 41$ 
viii

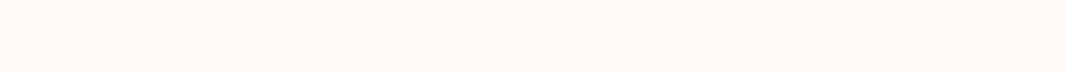




\section{BIOMOC, A Multispecies Solute-Transport Model with Biodegradation}

\section{By H. I. Essaid and B. A. Bekins}

\section{ABSTRACT}

A two-dimensional, multispecies reactive solute-transport model with sequential aerobic and anaerobic degradation processes was developed and tested. The model design is general and flexible, permitting simulation of biotransformation reactions for any combination of electron donor and acceptor. In addition, the evolution of redox zones can be simulated, as thermodynamically-favorable electron acceptors are depleted. The code is an extension of the U. S. Geological Survey's Method of Characteristics (MOC) flow and transport model. It allows for multiple particle sets and each particle set is capable of having multiple solute species with similar sorption characteristics. The rate of the degradation reactions can be represented by single-substrate Monod, multiple Monod, or minimum Monod kinetics. Four alternate inhibition formulations account for competitive, noncompetitive, biomass, or Haldane inhibition. Multiple degradation processes and microbial populations can be represented simultaneously. Growth of the biomass is modeled with specified yield and decay values.

The model has been successfully tested against several one-dimensional analytical solutions. These include transient transport with first- and zero-order decay and linear sorption and also steadystate transport with first- and zero-order decay, or Monod degradation. The model results were also compared to results from two other one-dimensional numerical codes.

To illustrate the flexibility of BIOMOC, example applications of the model to two field sites are described. The first example simulates steady-state, one-dimensional, transport and degradation of chlorinated solvents with no biomass growth. In this application, both reductive dehalogenation and aerobic degradation are simulated. The anaerobic reactions are inhibited by the presence of significant levels of dissolved oxygen. The second application is a two-dimensional, transient simulation of the Bemidji, Minnesota crude-oil spill site. In this application, the evolution of redox zones and microbial populations is simulated. Before contamination, aerobic conditions are present in the aquifer. As the plume evolves, the redox conditions change near the oil body from aerobic to manganese-reducing then iron-reducing and finally methanogenic. The results were used to determine the percentage of mass lost by aerobic versus anaerobic degradation and to understand the evolution of the redox zones in a plume. 


\section{INTRODUCTION}

A promising alternative to traditional pump-and-treat remediation is in situ bioremediation, a method that relies on natural and enhanced biodegradation processes at a site (Lee and others, 1988; Madsen, 1991; Bouwer and Zehnder, 1993; Salanitro, 1993; Macdonald and Kavanaugh, 1994). Both aerobic and anaerobic biodegradation processes can be effective at removing organic contaminants from the environment. The availability of electron acceptors determines the sequence of biodegradation processes. Based on the thermodynamics of reactions and redox potential, the theoretical sequence is aerobic degradation, followed by denitrification, manganese and iron reduction, sulfate reduction, and methanogenesis. This sequence may cause zonation of a contaminant plume with different biodegradation processes dominating in each redox zone (Baedecker and Back, 1979; Chapelle and Lovley, 1992; Lyngkilde and Christensen, 1992; Vroblesky and Chapelle, 1994). In addition, halogenated organic compounds may also serve as electron acceptors under sulfate-reducing and methanogenic conditions. Plume evolution is dynamic with the dominant biodegradation processes changing in time and space.

Numerical models that simulate transport and biodegradation processes are useful for integrating information collected in the field and studying the relative importance of simultaneously occurring processes (Borden and others, 1986; Rifai and others, 1988; Chiang and others, 1989; Thierrin and others, 1993). Field sampling limitations make it difficult to develop an accurate mass balance for the contaminant, and thus to distinguish the amount and rate of removal by biodegradation versus dilution and sorption. If sufficient data are available, a numerical model can be used to help answer these questions, estimate removal rates, predict plume evolution, and evaluate factors limiting biodegradation. Essaid and others (1995) summarized the existing models of transport and biodegradation. These models differ in dimensionality, representation of biological growth and contaminant degradation, and the number of processes simulated. Most are limited to specific biodegradation processes that include a maximum of two substrates (carbon sources) and two electron acceptors. Some models include the transport and uptake of substances necessary for microbial growth (for example nitrogen and phosphorous).

This report documents a general and flexible two-dimensional transport and biodegradation model that can handle multiple substrates and microbial populations, sequential terminal electron acceptor use, and cellular nutrient limitation. The governing equations and numerical methods are described. Model results are evaluated by comparison to analytical solutions and other numerical model results. In addition, two example field applications are described to demonstrate the flexibility of the model.

\section{THEORETICAL BACKGROUND AND GOVERNING EQUATIONS}

The U.S. Geological Survey's Method of Characteristics (MOC) transport model (Konikow and Bredehoeft, 1978; Goode and Konikow, 1989) was selected as the base for the biodegradation model because a robust transport model is required to handle the steep concentration gradients observed in field data without introducing significant numerical dispersion. In the original MOC code one set of particles was used to simulate transport of a single solute species. Variations of the MOC model exist that handle two concentrations per particle (Sanford and Konikow, 1985) and two particle sets with a single concentration each (Rifai and others, 1988). In this study, the MOC model was expanded to handle multiple particle sets, each particle having multiple solute species concentrations associated 
with it. This approach allows solute species having similar sorption characteristics to be represented by a single particle set. This modified version of the MOC code is referred to as BIOMOC.

\section{Flow Equation}

The equation describing transient two-dimensional flow of a homogeneous compressible fluid through a nonhomogeneous anisotropic aquifer is:

$$
S \frac{\partial h}{\partial t}=\frac{\partial}{\partial x_{j}}\left(b K_{j k} \frac{\partial h}{\partial x_{k}}\right)-W \quad j, \mathrm{j}=1,2
$$

where $S$ is the storage coefficient, $h$ is hydraulic head (L), $t$ is time (T), $K_{j k}$ is the hydraulic conductivity tensor $\left(\mathrm{LT}^{-1}\right), b$ is the aquifer thickness (L), $W$ is the source fluid flux (positive for outflow, negative for inflow) expressed as volumetric flux per unit area $\left(\mathrm{LT}^{-1}\right)$, and $x_{j}$ and $x_{k}$ are cartesian coordinates (L). By Darcy's Law, the average linear flow velocity in the $x_{j}$ direction $\left(V_{j}\right)$ is given by:

$$
V_{j}=-\frac{K_{j k}}{\varepsilon} \frac{\partial h}{\partial x_{j}}
$$

where $\varepsilon$ is the effective porosity (dimensionless).

\section{Transport Equation}

The two-dimensional transport equation solved in the model for each solute species is:

$$
R_{i} \frac{\partial C_{i}}{\partial t}=\frac{1}{b} \frac{\partial}{\partial x_{j}}\left(b D_{j k} \frac{\partial C_{i}}{\partial x_{k}}\right)-V_{j} \frac{\partial}{\partial x_{j}} C_{i}+\frac{W\left(C_{i}-C^{\prime}{ }_{i}\right)}{(\varepsilon b)}-R_{i} \lambda_{i} C_{i}-B_{i} \quad j, \mathrm{k}=1,2
$$

where $C_{i}$ is the concentration of the $i$ th solute $\left(\mathrm{ML}^{-3}\right), R_{i}$ is the retardation factor for the $i$ th solute, $D_{j k}$ is the dispersion tensor $\left(\mathrm{L}^{2} \mathrm{~T}^{-1}\right), C_{i}^{\prime}$ is the concentration of the $i$ th solute in the source fluid $\left(\mathrm{ML}^{-3}\right), \lambda_{i}$ is the first-order decay rate constant $\left(\mathrm{T}^{-1}\right)$ for the ith solute (half life $\left.\mathrm{t}_{1 / 2}=(\ln 2) / \lambda\right)$, and $B_{i}$ is the biodegradation reaction rate term $\left(\mathrm{ML}^{-3} \mathrm{~T}^{-1}\right)$ representing the total uptake of the $i$ th solute due to all active biodegradation processes. The first-order decay term is multiplied by the retardation factor because both dissolved and sorbed solute are assumed to decay (as in the case of radioactive solutes). However, the biodegradation term is not multiplied by the retardation factor because it is assumed that only the dissolved solute is degraded. Thus, biodegradation is slowed down by sorption.

\section{Biodegradation Terms}

Each solute may be involved in several biodegradation processes, such that the total uptake of any solute $i$ is given by the summation of the uptake for all simultaneously occurring biodegradation processes:

$$
B_{i}=\sum_{n=1}^{N} \beta_{i}^{n} v^{n}
$$

where $N$ is the total number of biodegradation processes, $v^{n}$ is the uptake rate of substrate by biodegradation process $n\left(\mathrm{ML}^{-3} \mathrm{~T}^{-1}\right)$, and $\beta_{i}^{n}$ is the uptake coefficient of solute $i$ for biodegradation 
process $n$. When the solute is the primary substrate, $\beta_{i}^{n}$ is equal to 1 . Otherwise, $\beta_{i}^{n}$ is determined by the stoichiometry of the reaction and is equal to the ratio of the mass of solute $i$ to that of the primary substrate. For example, if for every gram of carbon degraded aerobically, $2.6 \mathrm{gm}$ of dissolved oxygen is consumed, then the uptake coefficient for oxygen is 2.6. The value of $\beta_{i}^{n}$ is negative if solute $i$ is produced by the nth biodegradation process and is zero if the solute is not involved in the biodegradation process. An example of how to compute the uptake ratio for each solute is given in the section describing the application to chlorinated solvents.

The literature contains several conceptual models for bacterial growth and contaminant biodegradation (Baveye and Valocchi, 1989; Widdowson, 1991). In the simplest representation, macroscopic fluid substrate, electron acceptor, and cellular nutrient concentrations are used to calculate the growth and uptake. Two alternate representations, the biofilm and microcolony models, include pore scale processes and account for the effect of diffusion into and out of the biophase. BIOMOC is an implementation of the macroscopic approach, and thus, biophase diffusion has been neglected. It has also been assumed that the biomass remains attached to the sediments, and pore clogging by biomass growth is not accounted for in the model.

In general, a variation of Monod kinetics (Monod, 1949) is used to represent the growth and substrate uptake rate. Two different formulations exist for biodegradation processes that involve several solutes. The first formulation, referred to below as the multiple Monod formulation (Molz and others, 1986), assumes that the biodegradation reaction is limited by the concentration of each of the substances involved in the reaction:

$$
v^{n}=\frac{V_{\max }^{n}}{I_{n c}}\left\{\left(\frac{C_{1}}{K_{1}^{n} / I_{c}+C_{1}+I_{h}}\right)\left(\frac{C_{2}}{K_{2}^{n} / I_{c}+C_{2}+I_{h}}\right) \ldots\left(\frac{C_{m}}{K_{m}^{n} / I_{c}+C_{m}+I_{h}}\right)\right\} \frac{X_{k}^{n}}{I_{b}},
$$

where $V_{\max }^{n}$ is the asymptotic maximum specific uptake rate of the substrate $\left(\mathrm{T}^{-1}\right)$, and $K^{n}$ is the half-saturation constant $\left(\mathrm{ML}^{-3}\right), X_{k}^{n}$ is the biomass concentration of microbial population $k$ responsible for biodegradation process $n\left(\mathrm{ML}^{-3}\right)$. Although the bacteria are assumed to be attached, for convenience sake, biomass concentration is expressed as mass of bacteria per volume of fluid (equals biomass concentration per bulk aquifer volume divided by porosity). $I_{n c}, I_{c}$, and $I_{b}$ are the noncompetitive, competitive, and biomass inhibition factors, respectively, given by $I=1+Q_{s} / k_{s}$ where $Q_{\mathrm{s}}$ is the concentration of the inhibiting substance $s\left(\mathrm{ML}^{-3}\right)$, and $k_{s}$ is the inhibition constant for that substance $\left(\mathrm{ML}^{-3}\right)$ (Segel, 1975). An example of noncompetitive inhibition is the inhibition of an anaerobic biodegradation process by the presence of oxygen. Competitive inhibition is used to represent the inhibition of uptake of a secondary substrate when the primary substrate is still present. Biomass inhibition is an empirical means for limiting biomass growth formulated by Kindred and Celia (1989). The biomass inhibition factor for microbial population $k$ is given by $I_{b}=1+X_{k} / k_{b i o k}$ where $k_{\text {biok }}$ represents the biomass concentration above which the growth of population $k$ becomes limited. This capability may be used to prevent unbounded growth of the microbial population near a continuous source of contaminants. See the Bemidji, MN crude-oil site application for an example of its use. $I_{h}$ represents inhibition caused by the presence of compounds that are toxic. A modified form of Haldane inhibition (Haldane, 1930), that allows for inhibition by more than one compound (each with concentration $C_{i i}$ ), is used where $I_{h}=\sum C_{i i}^{2} / k_{h i i}$, is the sum over all inhibiting compounds, and $k_{h i i}$ is the Haldane inhibition constant for each $i i$ compound.

The alternative minimum Monod formulation (Kindred and Celia, 1989) assumes that a single solute is limiting the process: 


$$
v^{n}=\frac{V_{\text {max }}^{n}}{I_{n c}} M I N\left\{\left(\frac{C_{1}}{K_{1}^{n} / I_{c}+C_{1}+I_{h}}\right),\left(\frac{C_{2}}{K_{2}^{n} / I_{c}+C_{2}+I_{h}}\right), \ldots,\left(\frac{C_{m}}{K_{m}^{n} / I_{c}+C_{m}+I_{h}}\right)\right\} \frac{X_{k}^{n}}{I_{b}}
$$

Not enough experimental data are available to determine which modified Monod approach is more appropriate for field conditions. Therefore, to preserve generality and flexibility in the model, both formulations have been included as options in BIOMOC.

The metabolism of substrate will result in biomass growth if sufficient cellular nutrients are available. The rate of biomass growth for each population $k$ is given by:

$$
\overline{d X}_{k}=\left(P_{k}-d_{k}\right) X_{k} .
$$

where $P_{k}$ is the specific growth rate for population $k\left(\mathrm{~T}^{-1}\right)$, and $d_{k}$ is the specific death rate or maintenance constant $\left(\mathrm{T}^{-1}\right)$. Because microbes are observed to be ubiquitously present in the subsurface, in BIOMOC the biomass concentration is not allowed to decay to less than the initially specified background biomass concentration.

If growth is not limited by cellular nutrient availability, then the specific growth rate is the sum of the specific substrate uptake rates (substrate uptake rate per unit biomass) times the cell-yield coefficients, $Y$ (M bacteria/M substrate), for all $M$ biodegradation processes performed by population $k$.

$$
P_{k}=\frac{1}{X_{k} / I_{b}} \sum_{m=1}^{M} Y^{m} v^{m}
$$

If growth is cellular nutrient limited and the multiple Monod formulation of equation 5 is used, then:

$$
P_{k}=\frac{1}{X_{k} / I_{b}} \sum_{m=1}^{M} Y^{m} v^{m}\left(\frac{C_{n u t}}{K_{n u t} / I_{c}+C_{n u t}}\right) .
$$

If the minimum Monod formulation of equation 6 is used, then:

$$
P_{k}=\sum_{m=1}^{M} Y^{m} M I N\left[\frac{v^{m}}{X_{k} / I_{b}}, \frac{V_{\max }^{m}}{I_{n c}}\left(\frac{C_{n u t}}{K_{n u t} / I_{c}+C_{n u t}}\right)\right]
$$

where $Y_{n u t}$ is the cell-yield coefficient of the nutrient ( $\mathrm{M}$ bacteria/ $\mathrm{M}$ substrate), $C_{n u t}$ is the concentration of the nutrient $\left(\mathrm{ML}^{-3}\right)$, and $K_{n u t}$ is the half saturation constant for the nutrient $\left(\mathrm{ML}^{-3}\right)$. The net uptake of the nutrient is given by:

$$
v_{n u t}=\sum_{k=1}^{K}\left(\frac{1}{Y_{n u t}} P_{k} X_{k}-\frac{\Gamma_{n u t}}{Y_{n u t}} d_{k} X_{k}\right)
$$

where $K$ is the total number of microbial populations. $\Gamma_{n u t}$ is the nutrient release coefficient and represents the fraction of nutrient incorporated into biomass that becomes available for reuse when microbes die: if $\Gamma_{n u t}=1$ all biomass nutrient is recycled; if $\Gamma_{n u t}=0$ no nutrient is recycled. 


\section{Review of Assumptions}

A number of assumptions have been made in the development of the above theory and in its application to BIOMOC. These assumptions are summarized below and must be considered during application of the model to a field problem.

1. Flow in only two-dimensions is considered.

1. Darcy's law is valid.

2. Porosity and hydraulic conductivity are constant with time, and porosity is uniform in space.

3. Gradients of fluid density, viscosity, and temperature do not affect the velocity distribution.

4. Fluid and aquifer properties are not affected by the reactions that occur.

5. Ionic and molecular diffusion are neglected.

6. The aquifer is homogeneous and isotropic with respect to longitudinal and transverse dispersivity.

7. Both the dissolved and sorbed solute phases undergo first-order decay as represented by the $R_{i} \lambda_{i} C_{i}$ term in equation 3 . Only the dissolved solute undergoes biodegradation as represented by the biodegradation term, $B_{i}$, in equations 3 and 4 . First-order or zero-order decay of only dissolved solute can be approximated using this term (see Model Evaluation section).

8. There is no microbial transport, and the biomass concentration does not drop below the specified initial concentration.

9. A macroscopic approach has been used to represent biodegradation. Biophase diffusion is neglected.

\section{NUMERICAL METHODS}

The details of the numerical methods implemented for solving the flow and transport equations are fully described by Konikow and Bredehoeft (1978). The discretization uses a rectangular, uniformly spaced, block-centered, finite-difference grid. Implicit finite-difference equations are used to solve the flow equation (1). The average linear flow velocities are then calculated and used to solve the transport equation (3) using the method of characteristics and particle tracking.

Initially, particles of each set are distributed uniformly throughout the finite-difference grid. During a time step increment, each particle is moved based on the average linear velocity at the particle location. If there is sorption, the retarded velocity is used. After all the particles have been moved, an average concentration for each grid block is calculated based on the average of the concentrations of the particles located within the block. This new concentration, $C_{i}{ }^{*}$, is the result of advective transport only. Explicit finite-difference approximations are then used to solve for the change in concentration due to hydrodynamic dispersion, fluid sources, and changes in fluid storage using the average of the concentration from the previous time step and the advected concentration, $C_{i}{ }^{*}$. Changes in concentration due to first-order decay processes are calculated directly on particles to preserve accuracy.

All biodegradation terms (equations 5, 6, 8, 9, 10 and 11) are calculated explicitly using the average of the solute concentration from the previous time step and the advected solute concentration $\left(C_{i}{ }^{*}\right)$ in conjunction with the biomass concentration from the previous time step. Once the biodegradation uptake terms have been calculated for the time step, the amount of biomass growth is determined using the integral of equation (7) (Kindred and Celia, 1989): 


$$
X_{k}^{\text {new }}=X_{k}^{\text {old }} \exp \left[\left(P_{k}-d_{k}\right) \Delta t\right],
$$

where $X_{k}^{\text {new }}$ is the biomass concentration of microbial population $k$ at the end of the new time step, $X_{k}^{\text {old }}$ is the biomass concentration of microbial population $k$ from the previous time step, and $\Delta t$ is the time step size (T). Series expansion of the exponential term in equation (12) shows that this form is slightly more accurate than a finite-difference solution of equation (7).

An immobile set of particles may be specified to facilitate the representation of a solid phase such as iron coatings on sediment grains. These particles do not move and their concentration changes only as a result of biodegradation processes.

\section{Stability Criteria}

Explicit solution of the transport equation results in stability criteria that constrain the transport time step increment (Konikow and Bredehoeft, 1978). For dispersion, the following criterion must be satisfied:

$$
\Delta t \leq \operatorname{Min} \text { (overgrid) }\left[\frac{0.5}{\frac{D_{x x}}{(\Delta x)^{2}}+\frac{D_{y y}}{(\Delta y)^{2}}}\right] .
$$

To prevent the change in concentration at a source cell from exceeding the difference between the source concentration $\left(C_{i}^{\prime}\right)$ and the concentration in the aquifer $\left(C_{i}\right)$ the following criterion must be met:

$$
\Delta t \leq \operatorname{Min}\left(\text { overgrid) }\left[\frac{\varepsilon b_{j, k}}{W_{j, k}}\right]\right. \text {. }
$$

To maintain relatively uniformly spaced particles moving along relatively smooth and continuous pathlines the following accuracy criteria are established:

$$
\begin{aligned}
& \Delta t \leq\left[\frac{\delta \Delta x}{\left(V_{x}\right)_{\max }}\right], \\
& \Delta t \leq\left[\frac{\delta \Delta y}{\left(V_{y}\right)_{\max }}\right],
\end{aligned}
$$

where $\delta$ is the maximum fraction of a grid block dimension that a particle will be allowed to move during a transport time increment $(0<\delta \leq 1)$. The user specifies $\delta$ by setting the value of CELDIS in the input file.

The appropriate time increments needed to satisfy the stability criteria in equations (13) through (16) are computed automatically in the model. However, in addition to the above criteria, the biodegradation term is also sensitive to time step size. If the degradation rate is such that the half-life $\left(t_{1 / 2}\right)$ is the same order of magnitude as the time increment for a particle move step, accuracy problems may arise. This is because of the explicit method that is used to calculate the biodegradation terms. 
To illustrate the effect of time-step size on the stability of the biodegradation term, the transport and first-order decay of a solute were simulated using two approaches: (1) first-order decay and (2) the Monod expression for biodegradation. The Monod expression is approximately the same as firstorder decay when $K>>C$ :

$$
B=V_{\max }\left(\frac{C}{K+C}\right) \approx \frac{V_{\max }}{K} C \equiv \lambda C
$$

where $t_{1 / 2}=(\ln 2) / \lambda$.

First-order decay of a solute is calculated accurately for all time step sizes because it is calculated on a particle-by-particle basis (Goode and Konikow, 1989). On the other hand, the explicit calculation of the Monod biodegradation term is affected by time step size. The simulation results for the two cases are shown in figures $1 \mathrm{a}$ and $\mathrm{b}$. When the half-life is close to the time-step size, the solution obtained using the Monod expression oscillates about the solution obtained using first-order decay. When the time step size is cut by a factor of 5 , the two solutions converge.

In practice, the user should check the stability of the biodegradation term calculations by running the problem with different time step sizes for the particle move increments. This is achieved by varying CELDIS in the input.
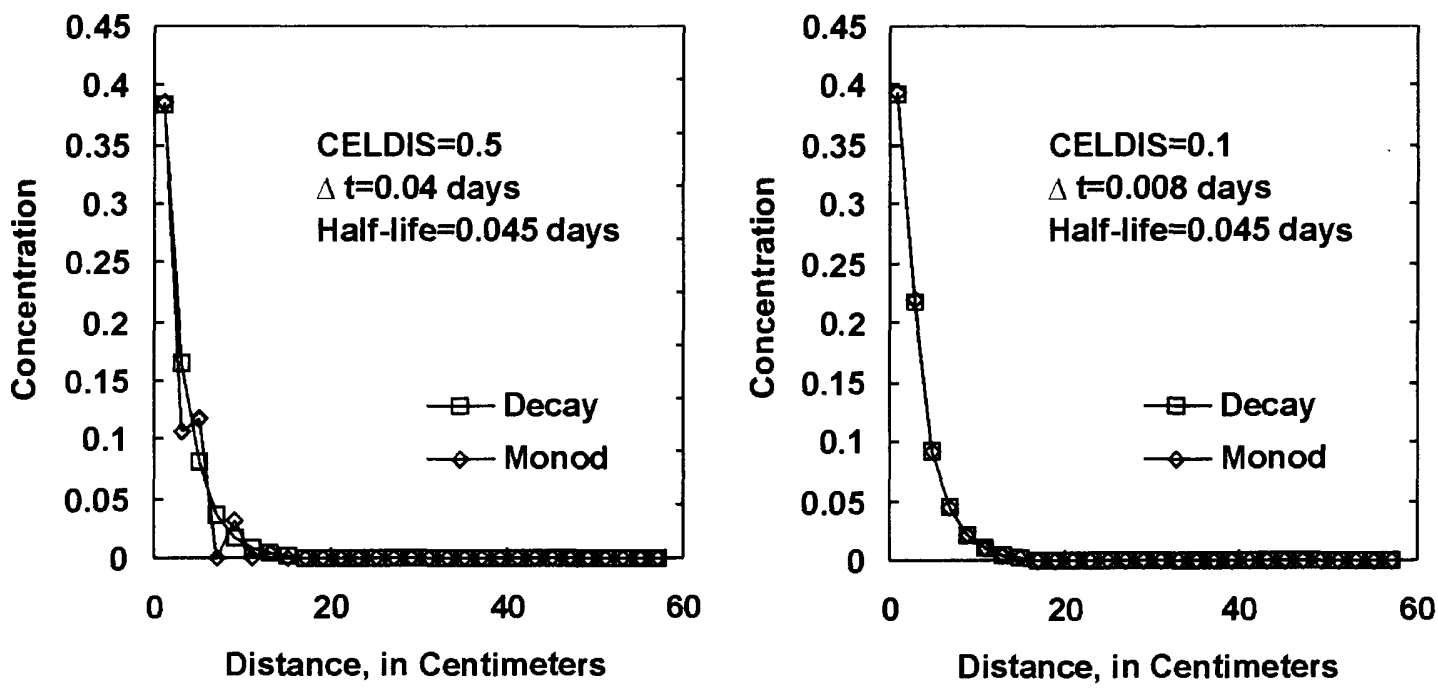

Figure 1. Plots showing the effect of time step size on biodegradation term accuracy.

\section{Boundary and Initial Conditions}

BIOMOC is a two-dimensional model. It may be used to simulate a two-dimensional areal aquifer, or a two-dimensional vertical cross-section through an aquifer (figure 2). For a twodimensional vertical cross-section, the thickness specified in the input is equal to the width of the slice 
and should be set to unity. Also, the aquifer hydraulic conductivity instead of transmissivity should be specified, and recharge occurs only in the top active grid blocks.

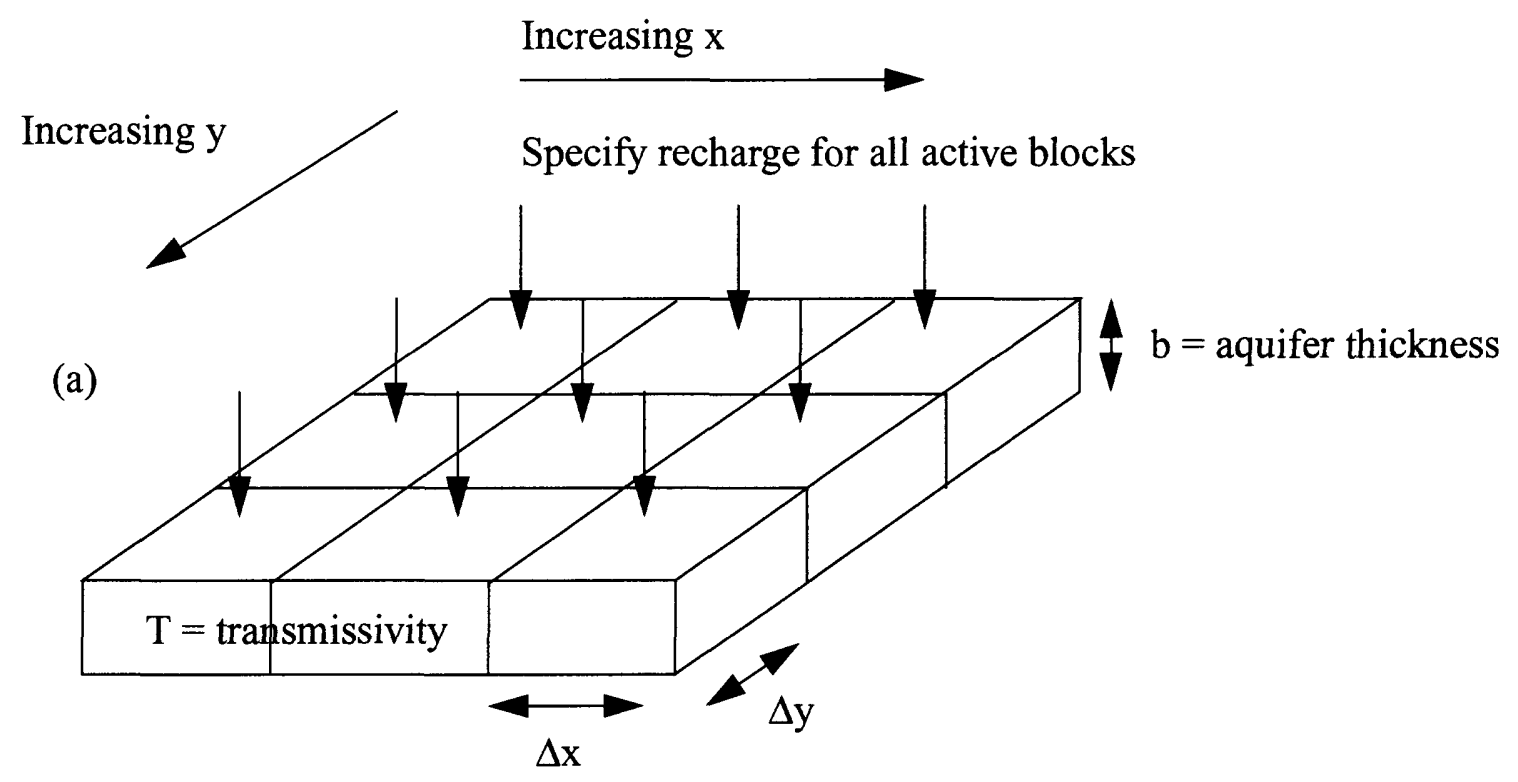

Specify recharge only for top active blocks

(set recharge $=0$ at all other blocks)

(b)

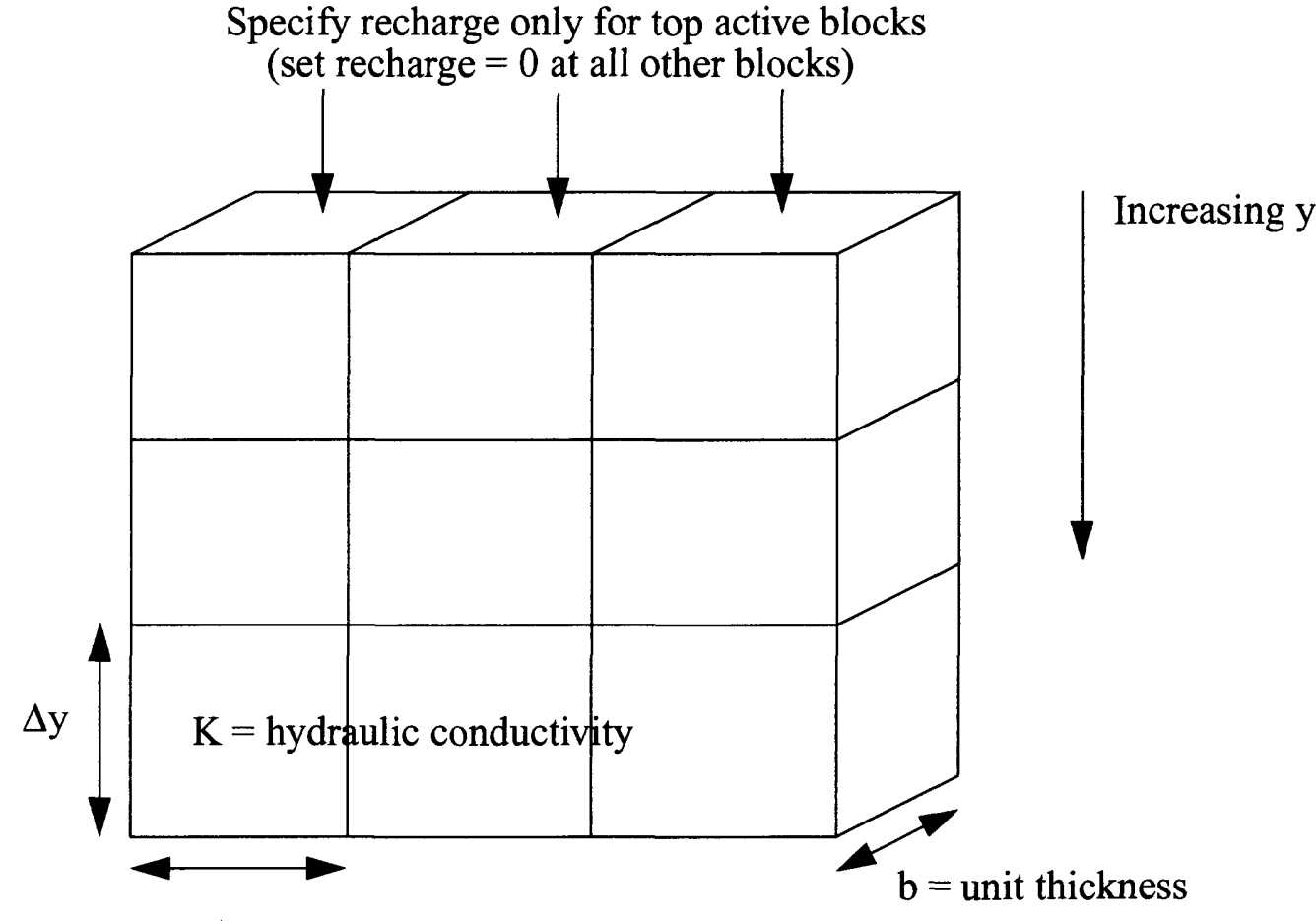

$\Delta \mathrm{x}$

Increasing $\mathrm{x}$

Figure 2. Geometry of (a) a two-dimensional areal simulation and (b) a vertical cross-section simulation illustrating the input parameters that must be specified for each case. 
To solve the flow and transport equations, boundary and initial conditions must be specified for each equation. Initial heads must be specified for the transient flow equation, and initial concentrations (solutes and microbes) must be specified for the transport equation. The boundary conditions that can be specified for the flow equation are: no flow, prescribed flux, and a leaky headdependent boundary that can also be used to set constant-head boundaries. No-flow boundaries are specified by setting the thickness (and hence transmissivity) of nodes to zero to prevent flow across the cell boundaries. BIOMOC requires that the model area be surrounded by a no-flow boundary, and therefore, the outer rows and columns of the finite-difference grid must have zero thickness. Within the model domain, inactive areas may be specified by setting the thickness to zero.

Prescribed flux boundaries may be set by specifying the flux rates for wells in the appropriate nodes (positive for withdrawal, negative for injection). Also, the recharge array may be used for this purpose. At leaky boundaries (for example, leakage through a confining layer or streambed):

$$
W(x, y, t)=-\frac{K_{z}}{m}\left(H_{s}-h\right),
$$

where $K_{z}$ is the vertical hydraulic conductivity of the confining layer $\left(\mathrm{LT}^{-1}\right) ; m$ is the thickness of the confining layer (L); and $H_{S}$ is the hydraulic head above the confining layer (L). $K_{z} / m$ is defined as the leakance coefficient of the confining layer and has units of $\left(\mathrm{T}^{-1}\right)$. Constant head nodes may be specified by assigning a high leakance coefficient (such as $1.0 \mathrm{~s}^{-1}$ ). This causes the head in the aquifer to be essentially equal to the specified value of $H_{s}$.

For solution of the transport equation, the solute concentrations in water entering the system across flow boundaries must be specified. If a constant-flux or leaky boundary represents a fluid source, then the chemical concentration of the source fluid ( $\left.C^{\prime}\right)$ must be specified. If the boundary is a fluid sink, the concentration of the fluid leaving the system is equal to the concentration of the water in the aquifer at the location of the sink.

\section{Mass Balance}

Fluid and solute mass balances are calculated and reported by BIOMOC at the end of each flow and chemical output step, respectively. Cumulative totals, and rates of, inflows and outflows are reported for fluid flow. For the chemical mass balance, cumulative mass fluxes, mass production and decay, and total dissolved mass are reported. Chemical mass balance errors are estimated by first computing the difference between the net mass flux and the change in mass storage. This difference is then converted to a fractional error by dividing by either: (1) the average of the net flux and the change in mass storage; or (2) the estimated total mass currently in the aquifer (given by the difference between the initial solute mass and the net mass flux). The first method is appropriate when the net flux is large compared to the initial mass in the aquifer. The second method is better when the initial mass is large compared to the net flux. Details of the mass balance calculations are given by Konikow and Bredehoeft (1978). 


\section{COMPUTER PROGRAM}

\section{General Program Features}

The details of the basic subroutines are documented by Konikow and Bredehoeft (1978). To avoid repetition, the discussion below will focus on the general features of the subroutines and their adaptation to handle multiple particle sets and biodegradation terms.

A list of the subroutines is given in table 1 and the general flow of the program is described below.

1. Input data are read into the program in subroutine PARLOD.

2. Particle sets are generated using the subroutine GENPT. The user specifies the number of particle sets to be used and the number of solutes associated with each particle set. Solutes with similar retardation coefficients can be associated with one particle set. An immobile particle set may also be specified to represent material on the sediments that is available for microbial utilization.

3. Subroutines ITERAT and SIP are used to solve the flow equation and determine the head distribution. For steady-state flow cases these subroutines are called only once. For transient flow cases, they are called at the beginning of each time step.

4. Average linear velocities are calculated using subroutine VELO, and stability criteria given in equations (15) and (16) are calculated using the maximum velocity of the particle set with the lowest retardation.

Table 1.--List of BIOMOC subroutines

\begin{tabular}{|c|c|}
\hline Name & Purpose \\
\hline MAIN & Control execution. \\
\hline PARLOD & Data input and initialization. \\
\hline ITERAT & Compute head distribution using subroutine SIP. \\
\hline SIP & Strongly Implicit Procedure solver. \\
\hline GENPT & Generate or reposition particles. \\
\hline VELO & $\begin{array}{l}\text { Compute hydraulic gradients, velocities, dispersion equation coefficients, and time } \\
\text { increment for stable solution of transport equation. }\end{array}$ \\
\hline MOVE & Move particles. \\
\hline CNCON & Compute change in chemical concentrations and mass balance for transport model. \\
\hline OUTPUT & Print head distribution and compute mass balance for flow model. \\
\hline CHMOT & Print concentrations, chemical mass balance, and observation well data. \\
\hline RETARD2 & $\begin{array}{l}\text { Compute nonlinear retardation factor and correction term for decay of sorbed } \\
\text { solute. }\end{array}$ \\
\hline SORB2 & Compute sorbed concentration corresponding to concentration in solution. \\
\hline $\mathrm{BIO} 1$ & Compute biodegradation terms using multiple Monod formulation \\
\hline $\mathrm{BIO} 2$ & Compute biodegradation terms using minimum Monod formulation. \\
\hline
\end{tabular}


5. Subroutine MOVE is called to track the movement of the particle sets. For each particle set, the average linear velocity is adjusted by the retardation factor and moved accordingly. The time interval of the move is determined by the stability criteria and may be less than the time step size for solution of the flow equation.

6. Subroutine CNCON is called from within MOVE to compute the changes in concentrations due to biodegradation, hydrodynamic dispersion, and source fluid mixing for each solute. To calculate the production or loss of each solute by biodegradation, subroutine BIO1 is called when the user specifies multiple Monod kinetics, and subroutine $\mathrm{BIO} 2$ is called when the user specifies minimum Monod kinetics. The mass balance for each individual solute is also calculated in CNCON.

7. When time step particle moves are completed, a new time step is begun and procedures 3 through 6 are repeated.

8. If all time steps in a pumping period are completed and if there are multiple pumping periods specified, PARLOD is called to read in the new pumping period specifications and steps 2 through 6 are repeated.

9. The program terminates when the specified simulation time is completed. Frequency of output is controlled by user specified options.

\section{Setting Dimensions}

A parameter file (DIMS.INC) has been set up to facilitate changes in problem dimensions (see table 2). To change any problem dimension, the user can simply change the value of the appropriate parameter in this file. For example, to change the maximum number of particle sets from 2 to 5 : parameter (NPS $=2$ )

should be changed to

parameter (NPS $=5)$.

A considerable amount of computational effort is used in moving particle sets. For this reason one should try to minimize the number of particle sets by grouping solutes with similar retardation factors onto a single particle set. In addition, computational effort may be minimized by solving the transport problem over a subarea of the flow domain using a transport subgrid.

\section{Input/Output File Information}

All input to BIOMOC is specified in the file INPUT.DAT. The specific formats for the input data are given in Appendix C. Any consistent set of length, mass, and concentration units may be used to specify input parameters. Time units should be seconds unless the input format specifies otherwise (for example the pumping period length, PINT, is in years). Many output files are generated during a BIOMOC simulation. These files are explained below.

1. BIOMOC.OUT: This file contains the general input and output information. The head distribution and fluid mass balance are reported in this file. Also, particle movement information and chemical mass balances are printed here.

2. BIOVEL.OUT: This is the file to which flow velocities are written if the user requests this option.

3. BIOPROF.OUT: This file contains the concentrations of all solutes and microbes along row 2 of the grid, for each chemical output interval. This corresponds to concentrations at the water table in a vertical cross-section simulation, or along the flow line of a one-dimensional simulation.

4. BIOOBSn.OUT: This file gives the time history of concentrations (solutes and microbes) at the $n$th observation well. The time (second column) is reported in units of days. 
Table 2.--Example DIMS.INC file used for setting up problem dimensions.

c flow $\mathrm{x}$-dimension

parameter $(\mathrm{NXD}=220)$

c flow $\mathrm{y}$-dimension

parameter $(\mathrm{NYD}=3)$

$\mathrm{c}$ transport $\mathrm{X}$-dimension

parameter $(\mathrm{NXC}=210)$

$\mathrm{c}$ transport y-dimension

parameter $(\mathrm{NYC}=3)$

c maximum number of particles

parameter (NPTS $=95000)$

c maximum number of particle sets

parameter (NPS $=2)$

c maximum number of solutes

parameter $(\mathrm{NSL}=5)$

c maximum number of microbial populations

parameter $(\mathrm{NMC}=1)$

c maximum number of microbial processes

parameter $(\mathrm{NPR}=5)$

c maximum number of observation points

parameter $(\mathrm{NOB}=5)$

c maximum number of profiles

parameter $(\mathrm{NPF}=15)$

c maximum number of concentrations per particle set

parameter $(\mathrm{NPC}=5)$

5. BIOHEAD.OUT: This is the file to which heads are written if the user requests this option.

6. BIOCON $n$.OUT: This is the file to which final concentrations of the $n t h$ solute are written at the end of the simulation.

7. BIOPOP $n$.OUT: This is the file to which final concentration values of the $n t h$ microbial population are written at the end of the simulation.

By default, BIOMOC is set up to handle a maximum of five BIOOBSn.out files, fifteen BIOCON $n$.OUT files, and four BIOPOP $n$.OUT files. These may be changed by editing the dimensions in line:

character*15 fname (5), fcname (15), fpname (4) ,

and adding the necessary file names to lines:

data fname/'bioobs1.out','bioobs2.out','bioobs3.out',

\&'bioobs4. out', 'bioobs5. out'/ 


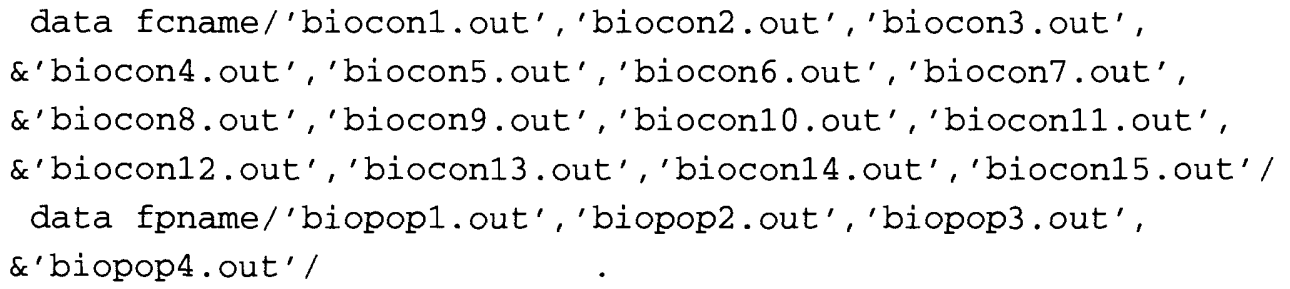

\section{MODEL EVALUATION}

To illustrate that BIOMOC correctly solves the governing equations in the model, several onedimensional test cases are presented. The first set of tests compares BIOMOC with analytical solutions for one-dimensional transport having various reaction formulations. The second test compares BIOMOC results to experimental and modeling results presented by Chen and others (1992) for toluene and benzene degradation. The third test is a comparison to results obtained using the one-dimensional model of Kindred and Celia (1989) to simulate aerobic biodegradation and denitrification with cellular nutrient limitation.

\section{One-Dimensional Transport with Linear Sorption, Decay, and Biodegradation}

Several analytical solutions are available for special cases of the equation describing onedimensional transport of a single solute with linear sorption, first-order decay, and biodegradation with no biomass growth. For this case, the applicable governing equation solved by BIOMOC is:

$$
R \frac{\partial C}{\partial t}=D \frac{\partial^{2} C}{\partial x^{2}}-v \frac{\partial C}{\partial x}-R \lambda C-V_{\max }\left(\frac{C}{K+C}\right)
$$

In this equation it is assumed that both the dissolved and sorbed solute undergo first-order decay (as in the case of a radioactive substance), however, only the dissolved solute undergoes biodegradation.

Analytical solutions for transient and steady-state first- and zero-order decay and steady-state Monod degradation are presented and used to evaluate model performance. These analytical solutions may also be used to fit field data and obtain estimates of field biodegradation rates for simple flow systems and simple degradation pathways.

The analytical solutions presented below all have a constant-concentration $\left(C_{o}\right)$ boundary condition at the inlet boundary. BIOMOC does not represent constant-concentration boundaries. Instead, in the BIOMOC simulations shown, an influx of water with a constant concentration of $C_{o}$ was used to represent the boundary. In some cases, this resulted in a simulated constant concentration at the inlet grid block that was slightly less than $C_{o}$. For these cases, the simulated concentration was used for $C_{o}$ in the analytical solution.

\section{Transient zero-order production and first-order decay with dispersion and linear sorption (van Genuchten and Alves, 1982)}

An analytical solution for the transient transport equation with first-order decay of dissolved solute and zero-order production has been developed by Selim and Mansell (1976) and is reported in van Genuchten and Alves (1982). The governing equation for this case is: 


$$
R \frac{\partial C}{\partial t}=D \frac{\partial^{2} C}{\partial x^{2}}-v \frac{\partial C}{\partial x}-\lambda C+\gamma
$$

where $\gamma$ is a zero-order decay term, and the first-order decay term, $\lambda$, is not multiplied by the retardation factor because it is assumed that sorbed solute does not decay. The initial and boundary conditions are given by:

and

$$
\begin{aligned}
& C=C_{i} \text { at } t=0 \text { for all } x, \\
& C=C_{0} \text { at } x=0, t>0,
\end{aligned}
$$

$$
\frac{\partial C}{\partial x}=0 \quad \text { at } x=L \text { for all } t .
$$

The solution is:

$$
C(x, t)=\left(C_{i}-\frac{\gamma}{\lambda}\right) A(x, t)+\left(C_{o}-\frac{\gamma}{\lambda}\right) B(x, t)
$$

where:

$$
\begin{gathered}
A(x, t)=\exp \left(\frac{-\lambda t}{R}\right)\left\{1-\frac{1}{2} \operatorname{erfc}\left[\frac{R x-v t}{2(D R t)}\right]-\frac{1}{2} \exp \left(\frac{v x}{D}\right) \operatorname{erfc}\left[\frac{R x+v t}{2(D R t)^{1 / 2}}\right]\right. \\
-\frac{1}{2}\left[2+\frac{v(2 L-x)}{D}+\frac{v^{2} t}{D R}\right] \exp \left(\frac{v L}{D}\right) \operatorname{erfc}\left[\frac{R(2 L-x)+v t}{2(D R t)^{1 / 2}}\right] \\
\left.+\left(\frac{v^{2} t}{\Pi D R}\right)^{1 / 2} \exp \left[\frac{v L}{D}-\frac{R}{4 D t}\left(2 L-x+\frac{v t}{R}\right)^{2}\right]\right\} \\
B(x, t)=B_{3}(x, t) / B_{4}(x), \\
B_{3}(x, t)=\frac{1}{2} \exp \left[\frac{(v-u) x}{2 D}\right] \operatorname{erfc}\left[\frac{R x-u t}{2(D R t)}\right]+\frac{1}{2} \exp \left[\frac{(v+u) x}{2 D}\right] \operatorname{erfc}\left[\frac{R x+u t}{2(D R t)^{1 / 2}}\right] \\
+\frac{(u-v)}{2(u+v)} \exp \left[\frac{(v+u) x-2 u L}{2 D}\right] \operatorname{erfc}\left[\frac{R(2 L-x)-u t}{2(D R t)^{1 / 2}}\right] \\
+\frac{(u+v)}{2(u-v)} \exp \left[\frac{(v-u) x+2 u L}{2 D}\right] \operatorname{erfc}\left[\frac{R(2 L-x)+u t}{2(D R t)^{1 / 2}}\right] \\
-\frac{v^{2}}{2 \lambda D} \exp \left(\frac{v L}{D}-\frac{\lambda t}{R}\right) \operatorname{erfc}\left[\frac{R(2 L-x)+v t}{2(D R t)^{1 / 2}}\right] \\
B_{4}(x)=1+\left(\frac{u-v}{u+v}\right) \exp \left[-\frac{u L}{D}\right]
\end{gathered}
$$

and

$$
u=v\left(1+\frac{4 \lambda D}{v^{2}}\right)^{1 / 2}
$$


For the special case of $\mathrm{K}>>\mathrm{C}$, the Monod kinetics term on the right-hand-side of (19) simplifies to $\left(V_{\max } / K\right) C$, a first-order decay term. If there is no sorption $(R=1)$, and $V_{\max } / K$ is set equal to $\lambda$, the decay term in (19), $R \lambda C$, and the Monod term are equivalent. Numerically, however, these two terms are evaluated very differently in BIOMOC. The first-order decay term is evaluated by decaying the concentrations of the particles directly, leading to an accurate solution. However, the Monod kinetics terms are calculated using the block concentrations obtained by averaging particle concentrations. Furthermore, the term is evaluated explicitly using the average of the concentration from the previous time step and the advected concentration. To test the accuracy of the explicit evaluation of the Monod term, a simulation was conducted with $R=1$ and Monod parameters such that $K>>C$ and $V_{\max } / K=\lambda$. The parameters used in the simulation are given in table 3. Because BIOMOC does not provide for constant concentration boundaries, a constant influx concentration boundary was used. Figure 3 shows that even though the Monod calculations are performed explicitly, there is excellent agreement between the numerical and analytical solutions.

Table 3.--Parameters used in transient zero-order decay, first-order decay, and first-order decay with sorption simulations.

\begin{tabular}{|c|c|c|c|}
\hline & $\begin{array}{c}\text { Zero-Order } \\
\text { Decay }\end{array}$ & First-Order Decay & $\begin{array}{c}\text { First-Order Decay with } \\
\text { Retardation }\end{array}$ \\
\hline \hline$L(\mathrm{~cm})$ & 200 & 200 & 200 \\
\hline$\Delta x(\mathrm{~cm})$ & 2 & 2 & 2 \\
\hline$D\left(\mathrm{~cm}^{2} / \mathrm{d}\right)$ & 37.5 & 37.5 & 37.5 \\
\hline$v(\mathrm{~cm} / \mathrm{d})$ & 25 & 25 & 25 \\
\hline$C_{i}(\mathrm{mg} / \mathrm{L})$ & 0 & 0 & 0 \\
\hline$C_{o}(\mathrm{mg} / \mathrm{L})$ & 1 & 1 & 1 \\
\hline$t_{1 / 2}(\mathrm{~d})$ & $1 \mathrm{e}+08$ & 4.5 & 4.5 \\
\hline$\lambda\left(\mathrm{d}^{-1}\right)$ & $7 \mathrm{e}-09$ & 0.154 & 0.154 \\
\hline$\gamma\left(\mathrm{d}^{-1}\right)$ & -0.154 & 0 & 0 \\
\hline$R$ & 1 & 1 & 2 \\
\hline$V_{\max }\left(\mathrm{d}^{-1}\right)$ & $1.54 \mathrm{e}-02$ & $1.54 \mathrm{e}+02$ & $1.54 \mathrm{e}+02$ \\
\hline$K(\mathrm{mg} / \mathrm{L})$ & 0.0001 & 1000 & 1000 \\
\hline$Y$ & 0 & 0 & 0 \\
\hline$X(\mathrm{mg} / \mathrm{L})$ & 1 & 1 & 1 \\
\hline$t(d)$ & 4 & 4 & 4 \\
\hline
\end{tabular}


When there is retardation due to linear sorption the numerical solutions obtained using decay and the Monod expression are no longer equivalent. For first-order decay, it is assumed in BIOMOC that the solute sorbed onto the solids also decays at the rate $\lambda$. However, for the biodegradation term it is assumed in BIOMOC that only solute in solution is biodegraded. Thus, the resulting concentrations are higher than for the first-order decay simulation. The difference between the two solutions is illustrated in figure 3. For field simulations in which both retardation and degrdation are significant, use of the BIOMOC biodegradation term more accurately represents the processes because only the dissolved phase is subject to biodegradation.

For the special case of $K<<C$, the Monod kinetics term on the right-hand-side of equation 19 simplifies to $V_{\max }$, a zero-order decay term equivalent to $-\gamma$ in equation 20 . A comparison of the analytical solution and the numerical solution for this special case is given in figure 3 and the parameters used in the model simulation are given in table 3 . There is excellent agreement between the numerical and analytical solutions.

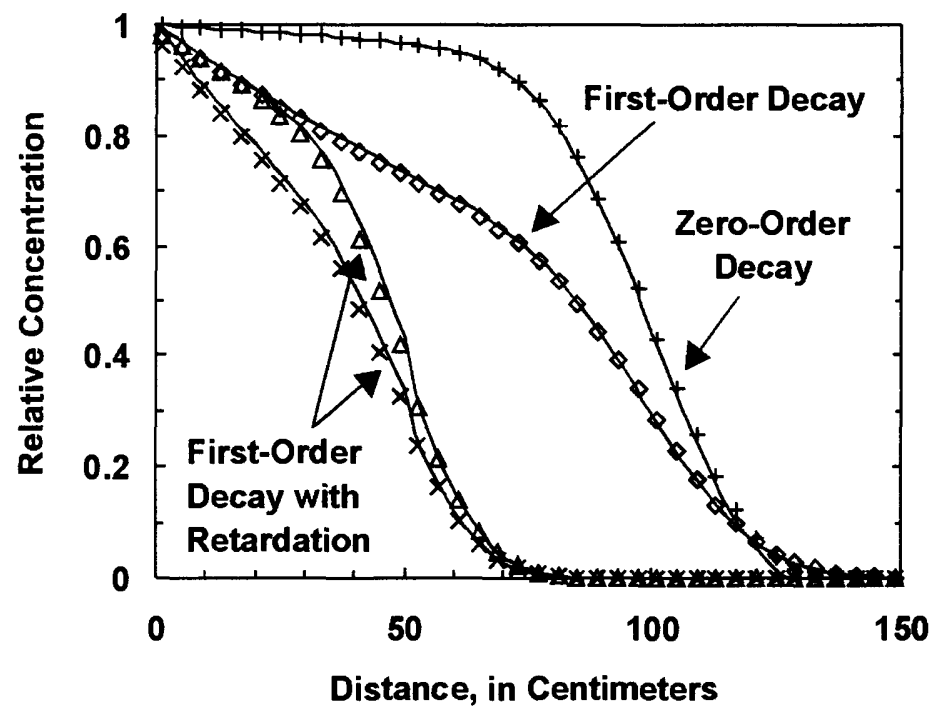

Figure 3. Comparison of analytical (lines) and numerical (points) solutions for transient zeroorder decay $(+)$, first-order decay $(\diamond)$, first-order decay of dissolved phase with retardation $(\Delta)$, and first-order decay of dissolved and sorbed phase with retardation (X). For the numerical solutions, only the values at the odd-numbered nodes are shown.

\section{Steady-state zero-order production and first-order decay with dispersion and linear sorption (van Genuchten and Alves, 1982)}

An analytical solution for the steady-state transport equation with first-order decay and zeroorder production has been developed by van Genuchten and Alves (1982). The governing equation is:

$$
0=D \frac{\partial^{2} C}{\partial x^{2}}-V \frac{\partial C}{\partial x}-\lambda C+\gamma
$$

with boundary conditions:

$$
C=C_{0} \text { at } x=0, t>0 \text {, }
$$


and

$$
\frac{\partial C}{\partial x}=0 \quad \text { at } x=L .
$$

The solution is:

$$
C(x)=\frac{\gamma}{\lambda}+\left(C_{o}-\frac{\gamma}{\lambda}\right) A(x)
$$

where:

$$
A(x)=\frac{\exp \left[\frac{(v-u) x}{2 D}\right]+\left(\frac{u-v}{u+v}\right) \exp \left[\frac{(v+u) x}{2 D}-\frac{u L}{D}\right]}{1+\left(\frac{u-v}{u+v}\right) \exp \left[-\frac{u L}{D}\right]}
$$

and

$$
u=v\left(1+\frac{4 \lambda D}{v^{2}}\right)^{1 / 2}
$$

Figure 4 shows a comparison between the analytical and numerical solutions for a case with zeroorder decay only, and a case with first-order decay. The parameters used for these solutions are given in table 4. In both cases the agreement between the two solutions is excellent. For the zero-order decay case there is a slight deviation from the analytical solution at the downgradient edge of the front.

\section{Steady-State Monod kinetics with no dispersion (Parlange and others, 1984)}

Parlange and others (1984) presented an analytical solution to equation (19) for the case of Monod degradation with no dispersion and no decay:

$$
x=\frac{v}{V_{\max }}\left[K \ln \left(\frac{C_{o}}{C}\right)+C_{o}-C\right],
$$

with boundary conditions:

and

$$
C=C_{0} \text { at } x=0,
$$

$$
\frac{\partial C}{\partial x}=0 \quad \text { at } x=L .
$$

This solution may be used to calculate the distance $\mathrm{x}$ corresponding to a given concentration $C(x)$. To evaluate the full Monod kinetics term calculation in equation (19), this analytical solution was compared to the numerical solution obtained using the parameters given in table 5 . The analytical and numerical solutions agree well as shown in figure 5. 
Table 4.--Parameters used in steady-state zero-order decay and first-order decay simulations.

\begin{tabular}{|c|c|c|}
\hline & $\begin{array}{c}\text { Zero-Order } \\
\text { Decay }\end{array}$ & First-Order Decay \\
\hline \hline$L(\mathrm{~cm})$ & 200 & 200 \\
\hline$\Delta x(\mathrm{~cm})$ & 2 & 2 \\
\hline$D\left(\mathrm{~cm}^{2} / \mathrm{d}\right)$ & 37.5 & 37.5 \\
\hline$v(\mathrm{~cm} / \mathrm{d})$ & 25 & 25 \\
\hline$C_{o}(\mathrm{mg} / \mathrm{L})$ & 0.939 & 0.924 \\
\hline$t_{1 / 2}(\mathrm{~d})$ & $1 \mathrm{e}+07$ & 1 \\
\hline$\lambda\left(\mathrm{d}^{-1}\right)$ & $7 \mathrm{e}-08$ & 0.693 \\
\hline$\gamma\left(\mathrm{d}^{-1}\right)$ & -0.5 & 0 \\
\hline$V_{m a x}\left(\mathrm{~d}^{-1}\right)$ & $5.01 \mathrm{e}-01$ & $6.93 \mathrm{e}+02$ \\
\hline$K(\mathrm{mg} / \mathrm{L})$ & 0.0001 & 1000 \\
\hline$Y$ & 0 & 0 \\
\hline$X(\mathrm{mg} / \mathrm{L})$ & 1 & 1 \\
\hline$t(\mathrm{~d})$ & 183 & 183 \\
\hline
\end{tabular}

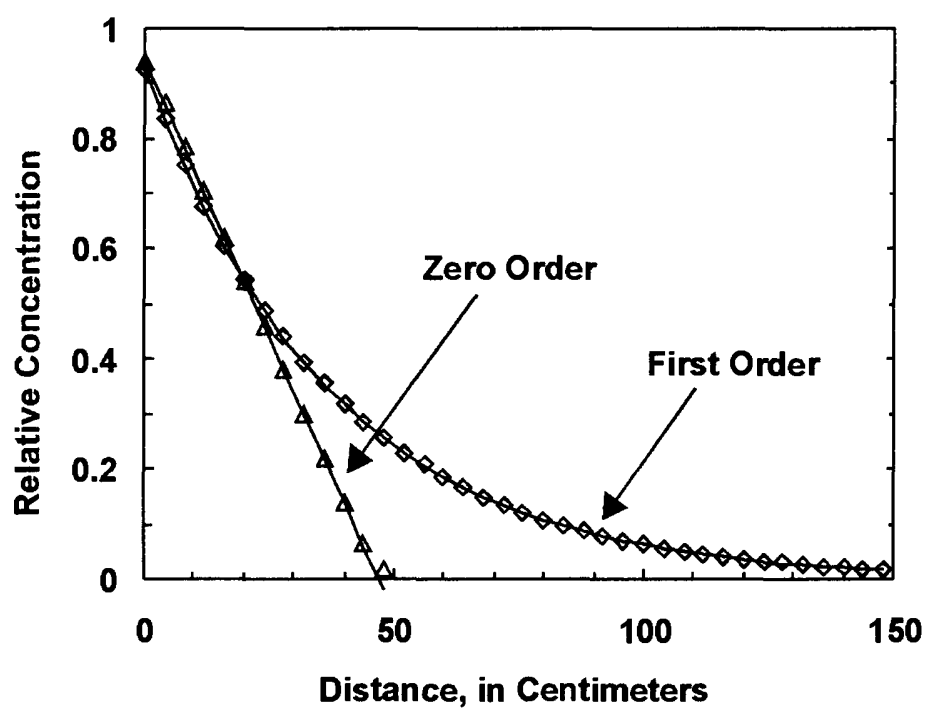

Figure 4. Comparison of analytical (lines) and numerical (points) solutions for steady-state zeroorder decay $(\Delta)$ and first-order decay $(\diamond)$. For the numerical solutions, only the values at the oddnumbered nodes are shown. 
Table 5.--Parameters used in steady-state Monod kinetics simulation.

\begin{tabular}{|c|c|}
\hline & Monod Kinetics \\
\hline \hline$L(\mathrm{~m})$ & 200 \\
\hline$\Delta x(\mathrm{~m})$ & 1 \\
\hline$v(\mathrm{~m} / \mathrm{d})$ & 0.1 \\
\hline$C_{o}(\mathrm{mg} / \mathrm{L})$ & 1 \\
\hline$V_{\max }\left(\mathrm{d}^{-1}\right)$ & $4.77 \mathrm{e}-03$ \\
\hline$K(\mathrm{mg} / \mathrm{L})$ & 0.5 \\
\hline$Y$ & 0 \\
\hline$X(\mathrm{mg} / \mathrm{L})$ & 1 \\
\hline$t(\mathrm{~d})$ & 1826 \\
\hline
\end{tabular}

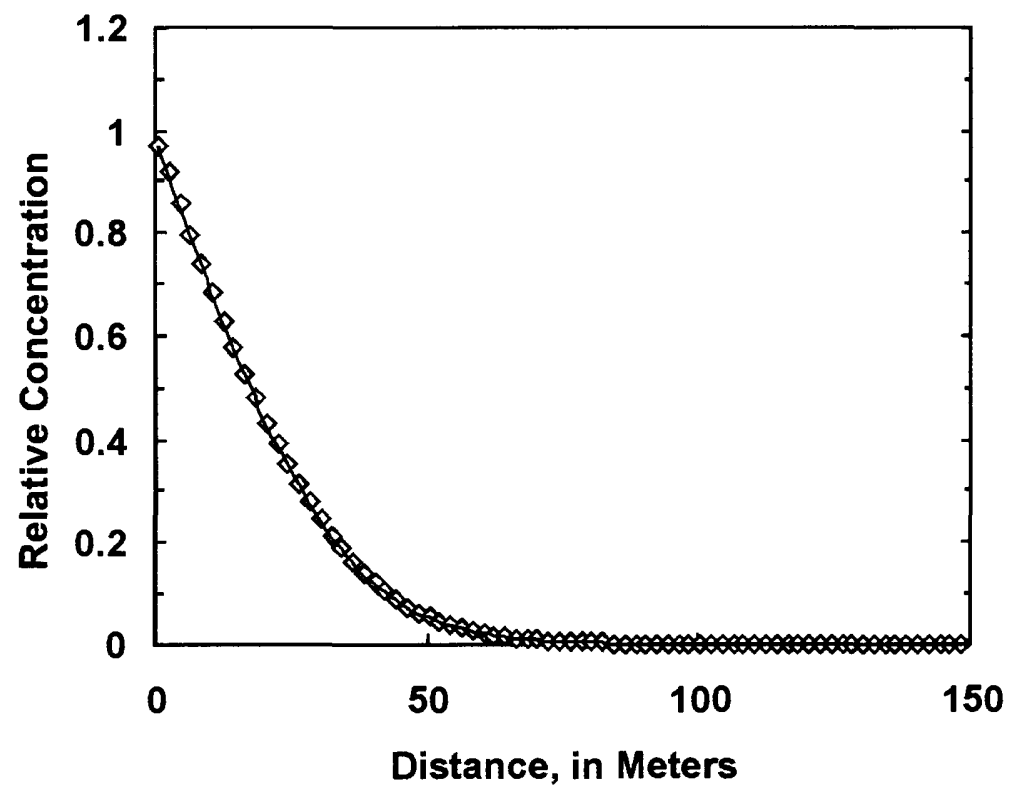

Figure 5. Comparison of analytical (line) and numerical (points) solutions for steady-state Monod kinetics. For the numerical solution, only the values at the even numbered nodes are shown. 


\section{Aerobic Biodegradation and Transport of Toluene and Benzene}

Chen and others (1992) presented experimental and simulation results for toluene and benzene transport and biodegradation in a continuous flow, water saturated, soil column. A constant composition solution of toluene $(20 \mathrm{mg} / \mathrm{L})$, benzene $(20 \mathrm{mg} / \mathrm{L})$, and hydrogen peroxide $(132.7 \mathrm{mg} / \mathrm{L})$ was fed to the column. Effluent samples were analyzed for toluene and benzene concentrations an a mathematical model was used to predict the effluent concentrations. Model parameters were independently estimated using laboratory measured and literature values (table 6). The modeling approaches used by Chen and others (1992) differ significantly from those in BIOMOC. They used the multiple Monod formulation, but represented the biomass as attached microcolonies with biophase diffusion. The governing equations were solved using the Galerkin finite-element method and a set iterative solution scheme.

Table 6.--Parameters used in the simulation of aerobic degradation of toluene and benzene.

$\begin{array}{ll}\text { Z-direction grid spacing } & 0.01 \mathrm{~m} \\ \text { Column length } & 0.56 \mathrm{~m} \\ \text { Porosity } & 0.38 \\ \text { Average linear velocity } & 0.33 \mathrm{~m} / \mathrm{d} \\ \text { Longitudinal dispersivity } & 0.0224 \mathrm{~m} \\ \text { Simulation time } & 10 \mathrm{~d} \\ \text { Time step size } & 0.005 \mathrm{~d}\end{array}$

Aerobic degradation of toluene

$\begin{array}{ll}\mathrm{V}_{\max } & 9.9 \mathrm{~d}^{-1} \\ \mathrm{~K}_{\mathrm{tol}} & 17.4 \mathrm{mg} / \mathrm{L} \\ \mathrm{K}_{\mathrm{DO}} & 0.1 \mathrm{mg} / \mathrm{L} \\ \mathrm{Y} & 0.5 \mathrm{mg} / \mathrm{mg} \\ \beta_{t o l} & 1.0 \\ \beta_{D O} & 2.19\end{array}$

Initial toluene degrading biomass, $X_{o}$

Toluene-degrading biomass death rate, $d_{k}$

$0.82 \mathrm{mg} / \mathrm{L}$

$0.1 \mathrm{~d}^{-1}$

Aerobic degradation of benzene

$\begin{array}{ll}\mathrm{V}_{\max } & 8.3 \mathrm{~d}^{-1} \\ \mathrm{~K}_{\text {tol }} & 12.2 \mathrm{mg} / \mathrm{L} \\ \mathrm{K}_{\mathrm{DO}} & 0.1 \mathrm{mg} / \mathrm{L} \\ \mathrm{Y} & 0.5 \mathrm{mg} / \mathrm{mg} \\ \beta_{\text {tol }} & 1.0 \\ \beta_{D O} & 2.15\end{array}$

Initial benzene degrading biomass, $X_{o}$

Benzene-degrading biomass death rate, $d_{k}$

$0.21 \mathrm{mg} / \mathrm{L}$

$0.1 \mathrm{~d}^{-1}$ 
Figure 6 shows the experimental data, the simulation results obtained by Chen and others (1992), and those obtained using BIOMOC with the multiple Monod formulation. The Chen and others model underpredicted toluene concentrations and BIOMOC gave a slight over-prediction. Chen and others found that their initial experimental estimate of benzene degrading biomass underpredicted benzene concentrations. They reduced the initial benzene degrading biomass by a factor of four in order to fit the experimental data (results shown in figure 6). Using the modified biomass estimate of Chen and others, benzene concentrations are overpredicted by BIOMOC, except at late times (figure 6). A good fit between BIOMOC and the experimental data can be obtained by reducing the experimental estimate of initial benzene degraders by only a factor of two (not shown). Thus, the difference in the two models is within the range of uncertainty in the benzene degrading biomass estimates.
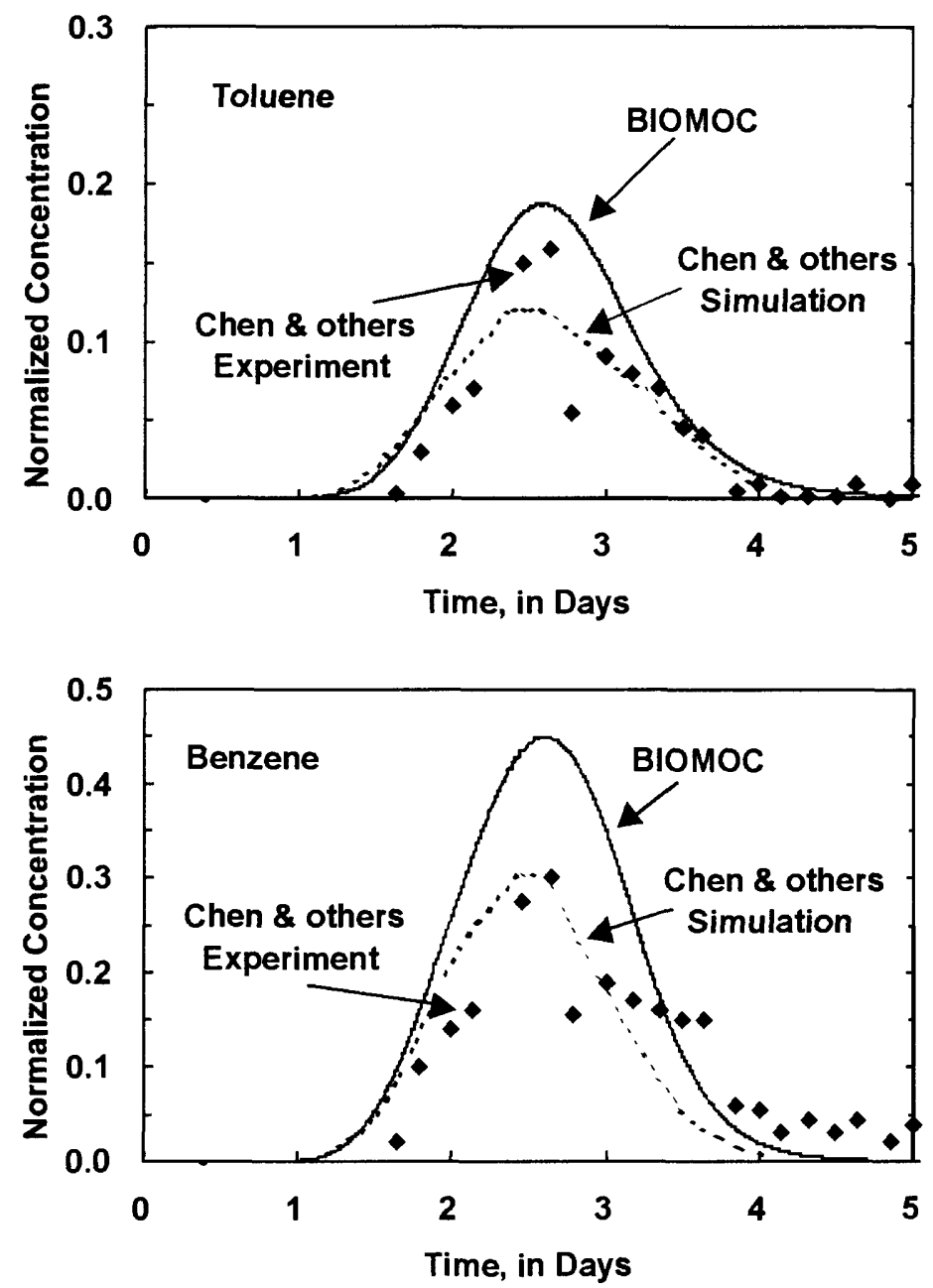

Figure 6. Experimental and simulation results of Chen and others (1992) and BIOMOC results for aerobic degradation of toluene and benzene. 


\section{Aerobic Biodegradation and Denitrification of a Substrate with Cellular Nutrient Limitation}

The model of Kindred and Celia (1989) (referred to as KC in the following discussion) was chosen for evaluation purposes because it is the most comprehensive in terms of biodegradation processes, and because of its accurate numerical method. The numerical method uses weight functions that adapt to the changing character of the nonlinear governing equations, thus providing very accurate results for reactive transport problems (Celia and others, 1989). The biodegradation reaction terms in the $\mathrm{KC}$ model are calculated using the macroscopic approach and the minimum Monod formulation. The minimum Monod formulation, as implemented by Kindred and Celia (1989), was used in the BIOMOC comparison simulations.

The test simulation included aerobic degradation of a substrate followed by denitrification, with cellular nutrient limitation (represented by availability of elemental nitrogen). Noncompetitive inhibition was used to suppress denitrification while dissolved oxygen was present. The $\mathrm{KC}$ model assumes that cellular nutrients incorporated into the biomass are released by decay and that the biomass can decay to less than the initial background concentration. To be consistent with the $\mathrm{KC}$ model, a modified form of BIOMOC that included these assumptions was used for this comparison. The flow and transport parameters used are given in table 7. A uniform, steady flow was used with initial substrate, dissolved oxygen, nitrate, and elemental nitrogen concentrations of $0,3,2$, and 0.01 $\mathrm{mg} / \mathrm{L}$, respectively. At the inlet, the substrate, dissolved oxygen, nitrate, and nitrogen concentrations were fixed at $10,3,2$, and $0.01 \mathrm{mg} / \mathrm{L}$, respectively. The right hand boundary condition for all solute concentrations was $d C / d x=0$.

The results, plotted in figure 7, show good agreement with some slight differences, mainly near the inlet where concentration changes are rapid and the difference in bacterial growth calculations between the two models becomes apparent. BIOMOC uses the average of the concentration from the previous time step and the concentration at the current time step after advection of the particles $\left(C_{i}^{*}\right)$ to explicitly calculate the biodegradation reaction terms and the biomass growth. The $\mathrm{KC}$ model uses extrapolated concentration values for the current time step to calculate the biodegradation reaction terms, and then uses the average of the extrapolated value and the new time step concentration value to calculate the biomass growth. The minor difference between the two solutions suggests that the computational savings gained by using an explicit approximation for these terms in BIOMOC is justified. 
Table 7.--Parameters used in the simulation of aerobic degradation and denitrification with cellular nutrient limitation.

X-direction grid spacing $\quad 2 \mathrm{~m}$

Porosity 0.38

Hydraulic conductivity, $\quad 1 \times 10^{-4} \mathrm{~m} / \mathrm{s}$

Average linear velocity $\quad 1.0 \mathrm{~m} / \mathrm{d}$

Longitudinal dispersivity $\quad 0.2 \mathrm{~m}$

Simulation time $68 \mathrm{~d}$

Time step size $\quad 0.2 \mathrm{~d}$

Aerobic degradation of substrate

$\begin{array}{ll}V_{\text {max }} & 1.0 \mathrm{~d}^{-1} \\ K_{\text {sub }} & 0.1 \mathrm{mg} / \mathrm{L} \\ K_{D O} & 0.14 \mathrm{mg} / \mathrm{L} \\ Y & 0.25 \mathrm{mg} / \mathrm{mg} \\ \beta_{\text {sub }} & 1.0 \\ \beta_{D O} & 2.0\end{array}$

Initial aerobic biomass, $X_{o}$

$0.2 \mathrm{mg} / \mathrm{L}$

Aerobic biomass inhibition constant, $k_{b i o}$

Aerobic biomass death rate, $d_{\text {aer }}$

$1.0 \mathrm{mg} / \mathrm{L}$

$0.01 \mathrm{~d}^{-1}$

Nitrate reduction of substrate:

$\begin{array}{ll}V_{\text {max }} & 1.0 \mathrm{~d}^{-1} \\ K_{\text {sub }} & 0.1 \mathrm{mg} / \mathrm{L} \\ K_{\text {nitrate }} & 0.1 \mathrm{mg} / \mathrm{L} \\ Y & 0.2 \mathrm{mg} / \mathrm{mg} \\ \beta_{\text {sub }} & 1.0 \\ \beta_{\text {nitrate }} & 2.0\end{array}$

Noncompetitive inhibition constant, $k_{n c} D O \quad 0.001 \mathrm{mg} / \mathrm{L}$ Nitrogen uptake:

$$
\begin{array}{ll}
K_{\text {nut }} & 0.01 \mathrm{mg} / \mathrm{L} \\
Y_{\text {nut }} & 7.0 \mathrm{mg} / \mathrm{mg}
\end{array}
$$

Initial nitrate-reducing biomass, $X_{o} \quad 0.1 \mathrm{mg} / \mathrm{L}$

Nitrate-reducing biomass inhibition constant, $k_{b i o} \quad 1.0 \mathrm{mg} / \mathrm{L}$

Nitrate-reducing biomass death rate, $d_{\text {nit }}$ 

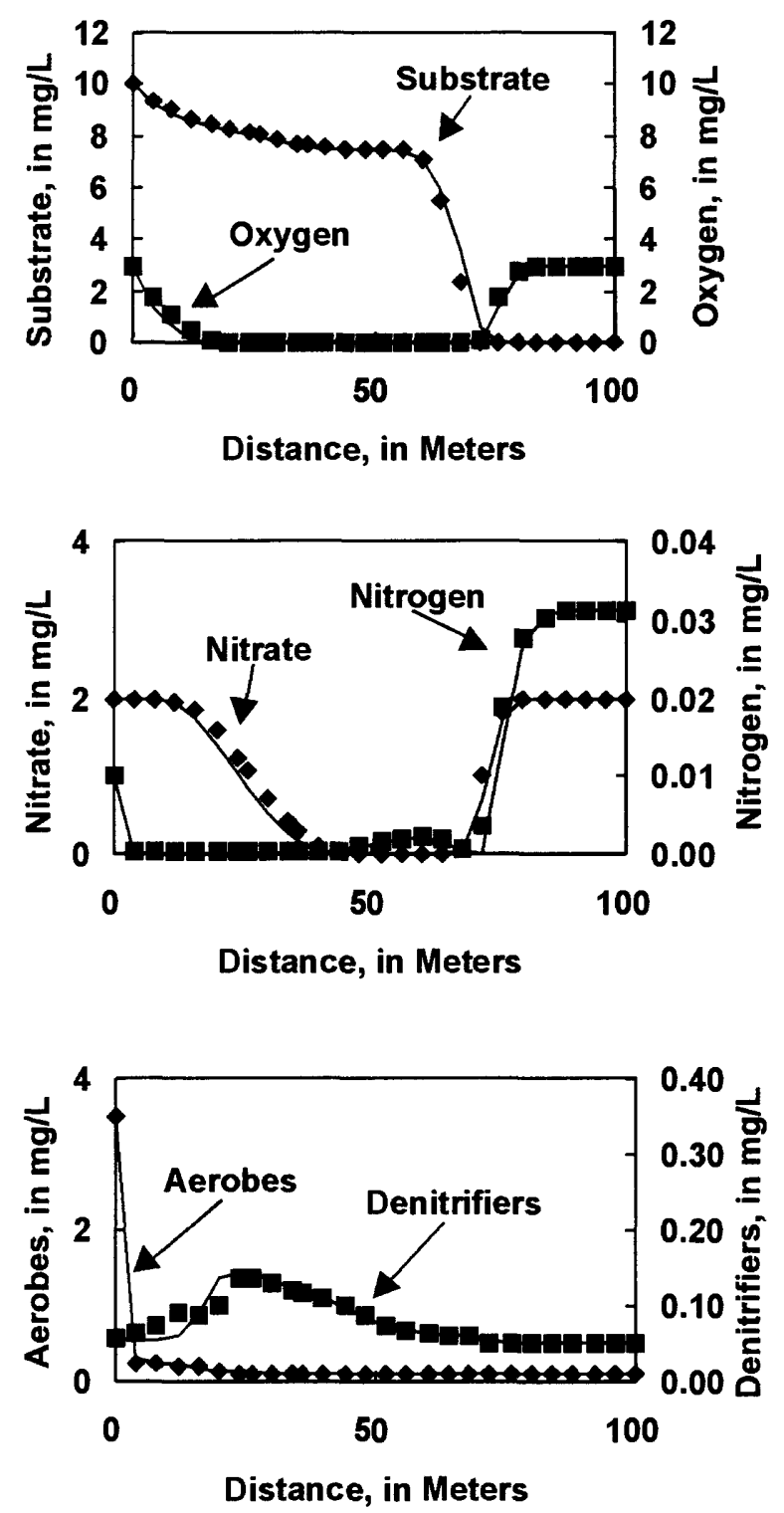

Figure 7. Simulation results obtained using BIOMOC (lines) and the model of Kindred and Celia (1989) (symbols) for aerobic degradation and nitrate reduction with cellular nutrient limitation.

\section{EXAMPLE APPLICATIONS}

To demonstrate the flexibility of BIOMOC and illustrate its use, two example applications of the model are described. The first example simulates steady-state, one-dimensional, transport and degradation of chlorinated solvents with no biomass growth at a site located on Dover Air Force Base, Delaware. In this application, both reductive dehalogenation and aerobic degradation are simulated. The anaerobic reactions are inhibited by the presence of significant levels of dissolved oxygen. The 
second application is a two-dimensional, transient simulation of the Bemidji, Minnesota crude-oil spill site. In this application, the evolution of redox zones and microbial populations is simulated.

The first step in applying BIOMOC to a field problem is to characterize the flow at the site and to define the geometry and boundary conditions of the system. In addition, a conceptual model of the biodegradation at the site must be developed. This includes defining the active biodegradation processes by specifying the substrates, reactants, products, and the microbial population mediating each process.

Following conceptual model development, estimates of flow, transport, and biodegradation parameters must be made. These may be based on a combination of field measurements and observations, laboratory values, and/or literature values. As with any model, there may be considerable uncertainty involved in estimating parameters and this should be taken into account in the interpretation of model results.

\section{Application to Chlorinated Solvents}

Over the past ten years, documentation of the biological transformation of chlorinated solvents in the environment has been steadily accumulating. The various reactions that can occur were reviewed by Vogel et al. (1987). Under strictly anaerobic conditions, tetrachloroethene (PCE), trichlorethene (TCE), dichlorethene (DCE), and vinyl chloride (VC) can be degraded by reductive dehalogenation (Vogel and McCarty, 1985). Under aerobic conditions, degradation of a primary substrate may result in cometabolic epoxidation of these compounds. More recently, VC and DCE have also been demonstrated to degrade when present as the sole carbon source (Davis and Carpenter, 1990; Klier and others, in press). The ideal conditions for natural attentuation of chlorinated solvents occur when either co-contaminants or natural organic carbon are present near the source to drive the initial steps of reductive dehalogenation (Wiedemeier et al., 1996). Once the initial contaminants are converted to less chlorinated compounds such as VC and DCE, these compounds will degrade if oxygen is present downgradient of the source area. In this example, the BIOMOC model is used to understand how an ideal zonation of anaerobic and aerobic conditions is established and maintained in an aquifer in which natural remediation of chlorinated solvents is occurring. The losses due to cometabolic transformation processes have been neglected. However, it is possible to account for these using the method given by Semprini et al. (1991) with the competitive inhibition capabilty of BIOMOC.

This example application is based on data from a site located on Dover Air Force Base where natural attenuation of chlorinated solvents is occurring. Using the model it was possible to analyze several important issues. First, because reductive dehalogenation reactions produce some contaminants as they consume others, it is necessary to model both the production and consumption of each compound. As a result of the full accounting provided by the model, it is possible to obtain the true transformation rate of each species rather than the net disappearance rate. Second, the reductive dehalogenation reactions occur only when dissolved oxygen (DO) concentrations are very low and a suitable electron donor is present. Using the model it is possible to determine the mechanism by which low dissolved oxygen conditions are maintaned near the source area and also whether adequate concentrations of an electron donor are present to drive the reductive dehalogenation. Finally, it was possible to examine the source of the dissolved oxygen that drives oxidation of the less chlorinated compounds downgradient of the source area. 


\section{Site Description}

A complete description of the site may be found in a report by the U.S. Army Corps of Engineers and Dames and Moore (1994). Figure 8 shows time-averaged data from a one-dimensional flowline beginning immediately under landfill LF 15 and including wells located $138 \mathrm{~m}, 218 \mathrm{~m}$, and $313 \mathrm{~m}$ downgradient, respectively. The presence of DCE, VC, and methane in samples from below LF15 indicates that the original waste PCE and TCE are partially transformed by reductive dehalogenation in the landfill before entering the ground water.
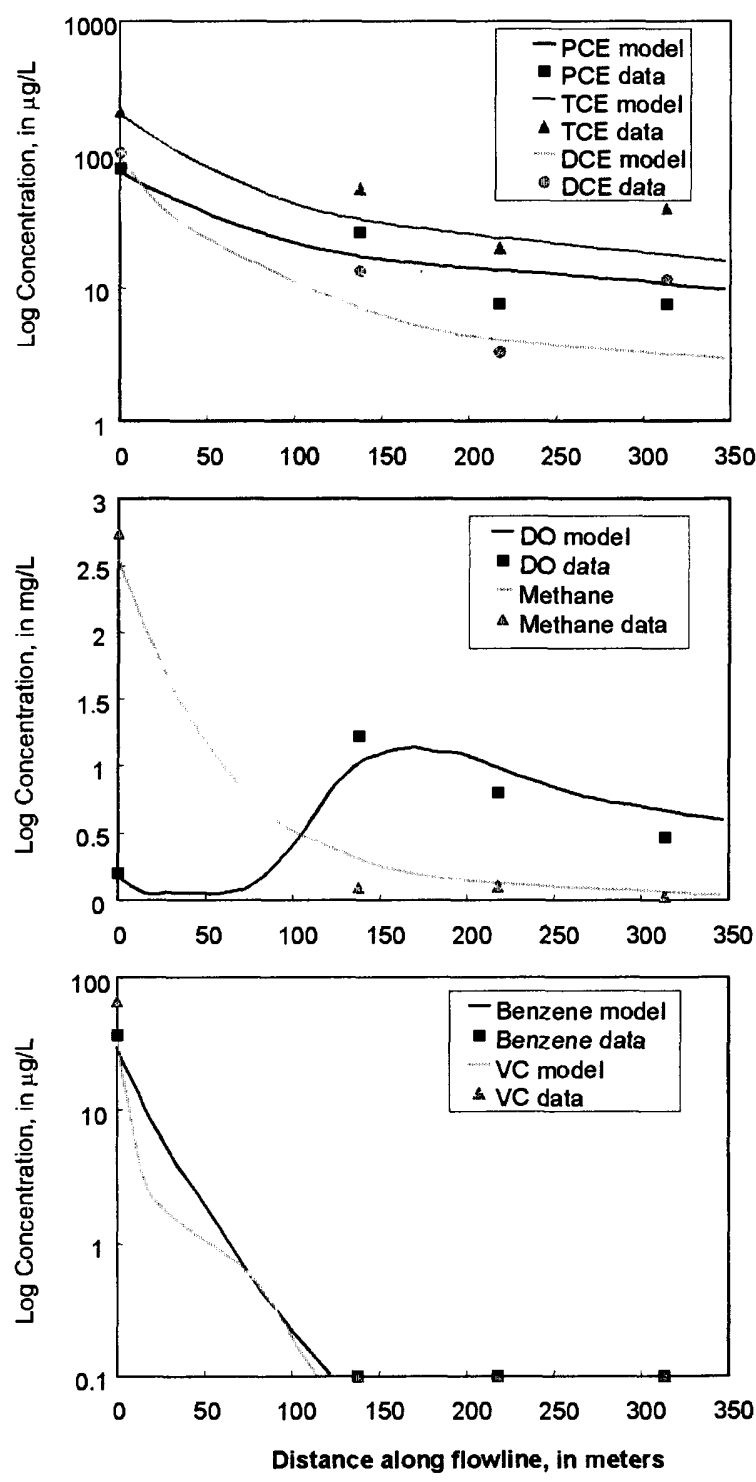

Figure 8. Comparison of modeled and observed concentrations of chlorinated aliphatics and other compounds along a simulated flowline at Dover AFB. The observed values are averages over four years. 
Within the ground water, a complex zonation of aerobic and anaerobic conditions prevails. Samples from the well at $138 \mathrm{~m}$ have non-detectable VC and benzene concentrations and DO values of about $1 \mathrm{mg} / \mathrm{L}$ which is about one-third of the background value. In addition, the concentrations of methane and the chlorinated degradation products have declined. The presence of higher DO, and the absence of $\mathrm{VC}$ and benzene indicates that aerobic transformation processes are important between the landfill and this location. Presumably the source of the DO is recharge water that enters the aquifer along a swale that runs between the two sites. Farther downgradient, along the same flowline, at 218 $\mathrm{m}$ and $313 \mathrm{~m}$, the concentrations of methane, DO, TCE, PCE, and DCE decline slowly. From these data is appears that influx of DO from recharge becomes less important and that DO levels decrease as methane and DCE are oxidized. In this area low average DO levels may coexist with anaerobic pockets in which reductive dehalogenation of PCE and TCE are coupled to oxidation of methane. These data provide a conceptual framework and constrain a one-dimensional model of the aerobic and anaerobic biotransformation processes acting on the contaminants downgradient of LF15.

\section{The Conceptual Model}

The redox conditions along a hypothetical flow path are anaerobic below the LF15 source area and evolve to slightly aerobic by the first monitoring well. By the third and fourth well, dissolved oxygen has again declined. Although the field conditions in the aquifer downgradient of LF15 are complex, a simple conceptual model serves to illustrate some of the important processes. Seven solutes and two microbial populations are accounted for in the model. The solutes are: PCE, TCE, DCE, VC, benzene, methane, and DO. These participate in seven biological transformation reactions: three anaerobic and four aerobic. In the three anaerobic reactions, methane oxidation is coupled to reductive dechlorination of PCE, TCE, and DCE. This reaction can also be coupled to other organic compounds that are present in the ground water such as benzene, low molecular weight fatty acids, and toluene. In the present model, methane is used because it has been detected in relatively high concentrations at the source area and it is also present in the downgradient wells. The model uses noncompetitive inhibition to slow the rate of reductive dehalogenation in the presence of significant DO concentrations. In the four aerobic reactions, DO is consumed during the oxidation of DCE, VC, benzene, and methane. The first microbial population consists of strict anaerobes that perform the three reductive dehalogenation reactions. The second microbial population consists of aerobic heterotrophs that perform the four aerobic transformations. Degradation by cometabolic processes was not accounted for in this conceptual model.

The model simulates concentrations along a hypothetical one-dimensional flow tube that starts below LF 15 and extends $457 \mathrm{~m}$ downgradient. The concentrations of PCE, TCE, DCE, and VC in the influx from the landfill are set to the average of the observed concentrations from 1988, 1989, 1994, and 1995. The concentration of benzene is set to the 1995 value because this is the highest benzene concentration ever observed below this landfill. The DO and methane concentrations are also set to the 1995 values because this is the first year that these concentrations were measured. Recharge water with a DO concentration of $10 \mathrm{ppm}$ enters the model flowline betwen the landfill and $198 \mathrm{~m}$ downgradient. This roughly corresponds to the location of a swale that overlies the flowpath in this area. The model was run for a period of eight years. This is a sufficient amount of time for the contamination front to migrate completely across the model length. Thus the results represent a steady-state simulation of the contaminant concentrations.

The above conceptual model was varied to test several alternate hypotheses. The source of dissolved oxygen in the ground water downgradient of the landfill was tested with two possible 
scenarios. In the first, dissolved oxygen entered only with the recharge water. In the second, a small amount of dissolved oxygen was present in the water below the landfill and dissolved oxygen was also supplied with the recharge water. Two possible electron donors for reductive dehalogenation were tested. These were benzene and methane. Finally, the amount of DCE transformed by aerobic versus anaerobic degradation was varied by adjusting the model concentration of dissolved oxygen that inhibits reductive dehalogenation. In this example, the results from the best conceptual model will be presented and the shortcomings of these alternate scenarios will be discussed.

\section{Model Parameter Estimates}

\section{Flow and transport parameters}

The values for the specified heads, the hydraulic conductivity and the recharge rate were based on estimates made by U.S. Army Corps of Engineers and Dames and Moore (1994). At the landfill end the flow boundary condition is set to a constant head of $3.66 \mathrm{~m}$ while at the downgradient boundary the head is set to $2.13 \mathrm{~m}$. The hydraulic conductivity is set to $27 \mathrm{~m} /$ day and the recharge rate over the first $198 \mathrm{~m}$ of the flow path is set to $39.4 \mathrm{~cm} / \mathrm{yr}$. The porosity is a uniform value of 0.3 . These values result in an average linear velocity of about $0.335 \mathrm{~m} / \mathrm{day}$, which is consistent with estimates of the velocity in the aquifer. Longitudinal dispersion is set to $0.3 \mathrm{~m}$ and transverse dispersivity is 0.003 $\mathrm{m}$. The model also includes the effect of linear sorption, and the values for $k_{d}$ were estimated using an organic carbon fraction of $250-350 \mathrm{mg} / \mathrm{kg}$ and octanol-water partition coefficients from the literature. Because of the low organic carbon fraction, only a minimal amount of the contaminants are sorbed to the aquifer material.

\section{Biodegradation kinetics parameters}

Initial first-order rates were estimated from the field data. Because the first-order degradation model is an approximation to the full Monod kinetics model, it is necessary to convert the first-order rate constants to Monod kinetics parameters for use in the BIOMOC model. The formula relating a first-order rate to the Monod kinetics parameters is: $k \sim V_{\max } / K$ where $\mathrm{k}$ is the first-order rate constant $\left(\mathrm{d}^{-1}\right), V_{\max }$ is the maximum specific substrate utilization rate $(\mu \mathrm{g} / \mathrm{L}-\mathrm{d})$, and $K$ is the half-saturation constant $(\mu \mathrm{g} / \mathrm{L})$. This expression has an approximation error of less than one percent when the value of $K$ is at least one hundred times that of the maximum simulated concentrations. Thus, in all cases, the value of $K$ was set to $10,000 \mu \mathrm{g} / \mathrm{L}$ to ensure that the Monod reaction kinetics in the code are approximately equivalent to first-order kinetics. In addition, the dependence on the microbial population is disabled by setting the biomass value for both microbial populations to 1.0 with a yield, of $\mathrm{Y}=0$. In this way, the reaction rate represents the ability of the aquifer to transform the contaminants. A noncompetitive inhibition expression is used to inhibit reductive dechlorination in the presence of DO. The effect of this expression is to slow the reaction rate when the concentration of DO is significant relative to the preset value of the inhibition constant. The inhibiting oxygen concentrations for the reductive dechlorination of PCE to TCE and TCE to DCE are set to $k_{n c} D O=800 \mu \mathrm{g} / \mathrm{L}$. The inhibiting oxygen concentration for the DCE to $\mathrm{VC}$ transformation is set to $k_{n c} D O=100 \mu \mathrm{g} / \mathrm{L}$. 


\section{Uptake coefficients}

The uptake coefficients for the reactions are computed from the reaction stoichiometries and the molecular weights. The following procedure was used to determine the model inputs. The reaction converting PCE to TCE is derived by coupling the half-reaction for the reductive dechlorination of PCE given by McCarty and Wilson (1992):

$$
\mathrm{CCl}_{2}=\mathrm{CCl}_{2}+\mathrm{H}^{+}+2 e^{-} \rightarrow \mathrm{CHCl}=\mathrm{CCl}_{2}+\mathrm{Cl}^{-}
$$

to the half-reaction for the oxidation of methane:

$$
\mathrm{CH}_{4}+2 \mathrm{H}_{2} \mathrm{O} \rightarrow \mathrm{CO}_{2}+8 e^{-}+8 \mathrm{H}^{+}
$$

The net reaction is:

$$
4 \mathrm{CCl}_{2}=\mathrm{CCl}_{2}+\mathrm{CH}_{4}+2 \mathrm{H}_{2} \mathrm{O} \rightarrow 4 \mathrm{CCl}_{2}=\mathrm{CCl}+\mathrm{CO}_{2}+4 \mathrm{HCl}
$$

The same method yields the following reactions for the reductive dechlorination of TCE and DCE coupled to methane oxidation:

$$
\begin{aligned}
& \mathrm{CHCl}=\mathrm{CHCl}+2 \mathrm{O}_{2} \rightarrow 2 \mathrm{CO}_{2}+2 \mathrm{HCl} \\
& 2 \mathrm{CH}_{2}=\mathrm{CHCl}+5 \mathrm{O}_{2} \rightarrow 4 \mathrm{CO}_{2}+4 \mathrm{HCl}+2 \mathrm{H}_{2} \mathrm{O} .
\end{aligned}
$$

Next the oxidation of DCE, VC, benzene, and methane are coupled to the reduction of DO:

$$
\begin{aligned}
& \mathrm{C}_{6} \mathrm{H}_{6}+15 \mathrm{O}_{2} \rightarrow 12 \mathrm{CO}_{2}+6 \mathrm{H}_{2} \mathrm{O} \\
& \mathrm{CH}_{4}+2 \mathrm{O}_{2} \rightarrow \mathrm{CO}_{2}+2 \mathrm{H}_{2} \mathrm{O} .
\end{aligned}
$$

These reactions are used to derive the uptake ratios of reactants and products for input to the BIOMOC program. Each reaction has a primary solute that has an uptake ratio of $\beta=1$. For the remaining solutes involved in the reaction, the uptake ratios, $\boldsymbol{\beta}_{i}$, are derived using the formula:

$$
\beta_{i}=\frac{\alpha_{i} \times M W_{i}}{\alpha_{1} \times M W_{1}}
$$

where $\alpha$ is the stoichiometric coefficient of the solute in the reaction and MW is the molecular weight. The subscript 1 refers to the primary solute for the reaction and the subscript $i$ refers to the solute for which the uptake ratio is being computed. The uptake ratios used for the seven modeled reactions are shown in table 8 . A positive value indicates that the compound is consumed and a negative value indicates production. Other model parameters used in the simulation are listed in table 9. Table 10 lists the section of the BIOMOC input file that specifies the biodegradation parameters to illustrate how the biodegradation processes and parameters of this example are setup in the model input.

\section{Model Results}

Figure 8 shows the model results and the data from the four wells along the flowline. The results in the plot represent a one-dimensional, steady-state solution to the equations. This is achieved after about 7 years. The PCE front takes the longest to migrate across the model domain because it is retarded by a factor of about 1.5 . Focusing first on the model DO curve, the DO entering the left boundary and with the recharge is consumed between 0 and $122 \mathrm{~m}$ by the oxidation of VC and benzene. When the DO is low, then the reductive dehalogenation reactions can take place. Thus where DO is low between 1 and $122 \mathrm{~m}$, the rate of PCE, TCE, and DCE reduction is fastest. The production of VC by the reduction of DCE causes the VC curve to flatten in this section. Beyond $122 \mathrm{~m}$, DO builds back up because benzene and $\mathrm{VC}$ are no longer present in significant concentrations and DO is continuing to enter with the recharge water until $198 \mathrm{~m}$. The DO increase causes the rate of 
Table 8.--Uptake coefficient used in the chlorinated solvent example.

\begin{tabular}{|c|c|c|c|l|l|l|l|}
\hline Reaction & $\beta_{\mathrm{PCE}}$ & $\beta_{\mathrm{TCE}}$ & $\beta_{\mathrm{DCE}}$ & $\beta_{\mathrm{VC}}$ & $\beta_{\text {benzene }}$ & $\beta_{\text {methane }}$ & \multicolumn{1}{|c|}{$\beta_{\mathrm{DO}}$} \\
\hline \hline$P C E \rightarrow T C E$ & 1 & -0.792 & 0 & 0 & 0 & 0.0241 & 0 \\
\hline$T C E \rightarrow D C E$ & 0 & 1 & -0.738 & 0 & 0 & 0.0304 & 0 \\
\hline$D C E \rightarrow V C$ & 0 & 0 & 1 & -0.644 & 0 & 0.0412 & 0 \\
\hline$D C E \rightarrow C \mathrm{O}_{2}$ & 0 & 0 & 1 & 0 & 0 & 0 & 0.660 \\
\hline$V C \rightarrow \mathrm{CO}_{2}$ & 0 & 0 & 0 & 1 & 0 & 0 & 1.29 \\
\hline benzene $\rightarrow \mathrm{CO}_{2}$ & 0 & 0 & 0 & 0 & 1 & 0 & 3.1 \\
\hline methane $\rightarrow \mathrm{CO}_{2}$ & 0 & 0 & 0 & 0 & 0 & 1 & 4.0 \\
\hline
\end{tabular}

reduction of PCE and TCE to slow down because they are inhibited by the presence of DO. However, the methane continues to be oxidized and this keeps the DO values at an intermediate level of about $800 \mu \mathrm{g} / \mathrm{L}$, allowing the reduction of PCE and TCE to continue at a slow rate. The reduction of DCE slows to a negligible amount because the inhibition concentration is set to $100 \mu \mathrm{g} / \mathrm{L}$. At this point, however, the oxidation of DCE can occur so that any DCE produced by TCE reduction is oxidized and the DCE values continue to drop with distance.

Several alternate scenarios were tested but, in each case, problems with the results suggest that the final scenario presented above better represents the processes occurring in the field. In one alternate scenario, dissolved oxygen was not present in the ground water entering the model boundary at the landfill and was supplied only with the recharge water. The simulation results, in this case, showed that the VC did not degrade by the second monitoring well at $138 \mathrm{~m}$. Based on the fact that VC has never been detected in this well, the modeling suggests that the oxygenated backgound water that mixes with the anaerobic infiltration below that landfill is an important source of DO. In another scenario, benzene was used as an electron donor instead of methane. However, because benzene is not present in the second monitoring well, it is not available to drive reductive dehalogenation downgradient of this well. Methane, however, is present in the wells farther downgradient. Thus with methane as the electron donor it is possible to simulate continued slow reductive dehalogenation over the section from 213 to $457 \mathrm{~m}$. Finally, the amount of DCE transformed by aerobic versus anaerobic degradation was varied by adjusting the concentration of dissolved oxygen in the model that inhibits reduction of DCE to VC. In the final modeling scenario, the reduction of DCE to VC was allowed to proceed only when DO was around $100 \mathrm{ppb}$ or lower. If the reaction is allowed to proceed at higher DO concentrations (up to $800 \mathrm{ppb}$ ), then VC accumulates in the downgradient part of the model. Because VC has never been detected in this area, the model results indicate that the reduction of DCE to $\mathrm{VC}$ reaction should be inhibited at DO concentrations of $100 \mathrm{ppb}$ or higher. The continued transformation of DCE in the downgradient part of the model where DO concentrations are above the inhibiting concentration occurs by aerobic degradation. 
Table 9.-- Model parameters used in the chlorinated solvent example.

\begin{tabular}{|c|c|}
\hline & \\
\hline $\begin{array}{l}\text { A-direction grid spacing } \\
\text { Total length }\end{array}$ & $\begin{array}{l}3.0 \mathrm{~m} \\
457 \mathrm{~m}\end{array}$ \\
\hline Porosity & 0.30 \\
\hline Average linear velocity & $0.34 \mathrm{~m} / \mathrm{d}$ \\
\hline Longitudinal dispersivity & $0.3 \mathrm{~m}$ \\
\hline Simulation time & $8.0 \mathrm{yr}$ \\
\hline Time step size & $2.7 \mathrm{~d}$ \\
\hline obic Biotransformation of $\mathrm{P}$ & $E$ to TCE \\
\hline$V_{\max }$ & $17.3 \mathrm{~d}^{-1}$ \\
\hline$K_{P C E}$ & $10,000 \mu \mathrm{g} / \mathrm{L}$ \\
\hline$K_{\text {meth }}$ & $0.1 \mu \mathrm{g} / \mathrm{L}$ \\
\hline$Y$ & $0.0 \mu \mathrm{g} / \mu \mathrm{g}$ \\
\hline $\mathrm{K}_{\mathrm{nc}} \mathrm{DO}$ & $800 \mu \mathrm{g} / \mathrm{L}$ \\
\hline
\end{tabular}

Initial PCE degrader biomass, $X_{o}$

PCE degrader biomass death rate, $d_{k}$

$1.0 \mu \mathrm{g} / \mathrm{L}$

$0.0 \mathrm{~d}^{-1}$

The parameters for the other anaerobic reactions are identical to those for PCE except:

TCE to DCE $\quad V_{\max } \quad 30 \mathrm{~d}^{-1}$

DCE to VC $\quad V_{\max } \quad 53 \mathrm{~d}^{-1}$

$\mathrm{K}_{\mathrm{nc}} \mathrm{DO} \quad 100 \mu \mathrm{g} / \mathrm{L}$

Aerobic Biotransformation of DCE to $\mathrm{CO}_{2}$

$$
\begin{array}{ll}
V_{\max } & 70 \mathrm{~d}^{-1} \\
K_{D C E} & 10,000 \mu \mathrm{g} / \mathrm{L} \\
K_{D O} & 0.1 \mu \mathrm{g} / \mathrm{L} \\
Y & 0.0 \mu \mathrm{g} / \mu \mathrm{g}
\end{array}
$$

Initial aerobic DCE degrader biomass, $X_{o} \quad 1.0 \mu \mathrm{g} / \mathrm{L}$

aerobic DCE degrader biomass death rate, $d_{k} \quad 0.0 \mathrm{~d}^{-1}$

The parameters for the other aerobic reaction are identical to those for DCE except:

$\begin{array}{lll}\mathrm{VC} \text { to } \mathrm{CO}_{2} & V_{\max } & 518 \mathrm{~d}^{-1} \\ \text { benzene to } \mathrm{CO}_{2} & V_{\max } & 100 \mathrm{~d}^{-1} \\ \text { methane to } \mathrm{CO}_{2} & V_{\max } & 35 \mathrm{~d}^{-1}\end{array}$


Table 10.-- Biodegradation model parameters, and their description, from the BIOMOC input file for the chlorinated solvent example. Solutes one through seven are: PCE, TCE, DCE, VC, benzene, dissolved oxygen, and methane, respectively. Microbial populations one and two are: anaerobes that perform reductive dehalogenation and aerobes, respectively. Biodegradation processes one through seven are: reductive dehalogenation of PCE, TCE, and DCE, and oxidation of DCE, VC, benzene, and methane, respectively. (is is an index for solutes involved in a particular biodegradation process, $k s$ is an index for all solutes simulated, $i b$ is an index for microbial population, $n c$ is an index for all solutes acting with a given inhibition type on a biodegradation process. Other parameters are defined in Appendix B)

\begin{tabular}{|c|c|c|}
\hline & 7 & [nproc] \\
\hline \multirow[t]{4}{*}{2} & $2.00 \mathrm{e}-04 \quad 10.000100[\operatorname{nsproc}(1)][\operatorname{vmax}(1)$ & ][iz(1)][yield(1)] [ncomp (1)] [nnc(1)] [nhal (1)] \\
\hline & $110000 . \quad 7 \quad 0.1$ & {$[\operatorname{ksproc}(1, i s)][h f k(1, i s)]$} \\
\hline & 6800 & {$[\operatorname{ksnc}(1, n c)][\operatorname{facnc}(1, \mathrm{nc})]$} \\
\hline & 1. $-\begin{array}{lllllll}0.792 & 0.0 & 0.0 & 0.0 & 0.0 & 0.0241\end{array}$ & {$[\operatorname{upcoef}(1, \mathrm{ks})]$} \\
\hline \multirow[t]{4}{*}{2} & $3.50 e-04 \quad 1 \quad 0.0 \quad 00100[\operatorname{nsproc}(2)][\max (2)$ & ] [iz $(2)][$ yield $(2)][\operatorname{ncomp}(2)][\operatorname{nnc}(2)][\operatorname{nhal}(2)]$ \\
\hline & $210000 . \quad 7 \quad 0.1$ & {$[\operatorname{ksproc}(2$, is $)][$ hfk $(2, i s)]$} \\
\hline & 6800 & {$[\operatorname{ksnc}(2, n c)][\operatorname{facnc}(2, n c)]$} \\
\hline & $\begin{array}{llllllll}0.0 & 1.0 & -0.738 & 0.0 & 0.0 & 0.0 & 0.0304\end{array}$ & [upcoef $(2, \mathrm{ks})]$ \\
\hline \multirow[t]{4}{*}{2} & $6.13 e-0410.0 \quad 0 \quad 100[n \operatorname{sproc}(3)][\max (3)$ & ]$[$ iz (3)] [yield (3)] [ncomp (3)] [nnc(3)] [nhal (3)] \\
\hline & $\begin{array}{llll}3 & 10000 & 7 & 0.1\end{array}$ & {$[\operatorname{ksproc}(3, i s)][h f k(3, i s)]$} \\
\hline & 6100 & {$[\operatorname{ksnc}(3, \mathrm{nc})][\operatorname{facnc}(3, \mathrm{nc})]$} \\
\hline & $\begin{array}{lllllll}0.0 & 0.0 & 1.0 & -0.644 & 0.0 & 0.0 & 0.0412\end{array}$ & {$[\operatorname{upcoef}(3, \mathrm{ks})]$} \\
\hline \multirow[t]{3}{*}{2} & $8.10 e-0420.0 \quad 0 \quad 0 \quad 0 \quad[n \operatorname{nsproc}(4)][\operatorname{vmax}(4)$ & ]$[$ iz $(4)][$ yield $(4)][$ ncomp $(4)][$ nnc $(4)][$ nhal $(4)]$ \\
\hline & $\begin{array}{llll}3 & 10000 & 6 & 0.1\end{array}$ & {$[\operatorname{ksproc}(4, i s)][\mathrm{hfk}(4, i s)]$} \\
\hline & $\begin{array}{lllllllll}0.0 & 0.0 & 1.0 & 0.0 & 0.0 & 0.660 & 0.0\end{array}$ & {$[\operatorname{upcoef}(4, \mathrm{ks})]$} \\
\hline \multirow[t]{3}{*}{2} & $6.00 e-03220.000000[n \operatorname{sproc}(5)][\operatorname{vmax}(5)$ & ] [iz (5)] [yield (5)] [ncomp (5)] [nnc(5)] [nhal (5)] \\
\hline & $\begin{array}{llll}4 & 10000 & 6 & 0.1\end{array}$ & {$[\operatorname{ksproc}(5, i s)][\operatorname{hfk}(5, i s)]$} \\
\hline & $\begin{array}{llllllll}0.0 & 0.0 & 0.0 & 1.0 & 0.0 & 1.28 & 0.0\end{array}$ & {$[\operatorname{upcoef}(5, \mathrm{ks})]$} \\
\hline \multirow[t]{3}{*}{2} & $1.16 \mathrm{e}-03220.0 \quad 00000[\operatorname{nsproc}(6)][\operatorname{vmax}(6)$ & ] [iz $(6)][$ yield $(6)][$ ncomp $(6)][\operatorname{nnc}(6)]$ [nhal $(6)]$ \\
\hline & $\begin{array}{llll}5 & 10000 & 6 & 0.1\end{array}$ & {$[\operatorname{ksproc}(6, i s)][h f k(6, i s)]$} \\
\hline & $\begin{array}{lllllll}0.0 & 0.0 & 0.0 & 0.0 & 1.0 & 3.10 & 0.0\end{array}$ & {$[$ upcoef $(6, k s)]$} \\
\hline \multirow[t]{6}{*}{2} & $4.00 e-0420.0 \quad 0 \quad 000 \quad[n \operatorname{sproc}(7)][\operatorname{vmax}(7)$ & ]$[$ iz (7) ] [yield (7) ] [ncomp (7)] [nnc (7)] [nhal (7) ] \\
\hline & $\begin{array}{llll}6 & 0.1 & 7 & 10000\end{array}$ & {$[\operatorname{ksproc}(7$, is $)][\operatorname{hfk}(7$, is $)]$} \\
\hline & $\begin{array}{lllllll}0.0 & 0.0 & 0.0 & 0.0 & 0.0 & 4.00 & 1.00\end{array}$ & {$[\operatorname{upcoef}(7, \mathrm{ks})]$} \\
\hline & & [numnut] \\
\hline & $0.0 e-06 \quad 0.0 e-06$ & [death $(i b)]$ \\
\hline & $\begin{array}{lll}0 & 0.00 & 0.00\end{array}$ & [nzinhib] [zinhibfac] \\
\hline 1 & .0000 & {$[z 1]$} \\
\hline & .0000 & [z2] \\
\hline
\end{tabular}

\section{Simulation of the Bemidji, Minnesota Crude-Oil Spill Site}

Petroleum hydrocarbons represent the largest class of contaminants in found in groundwater. It is well established that much of the soluble fraction of a non-aqueous petroleum hydrocarbon source biodegrades under both anaerobic and aerobic conditions. However, both the rate of degradation and the specific compounds that can be degraded depend strongly on the aquifer redox conditions. Commonly, insufficient oxygen is present in the native groundwater to mineralize the contaminant fluxes from the source and the core of the plume is anaerobic. For this reason, a model that accounts 
for all of the potential electron acceptors is necessary to evaluate the biodegradation capacity of an aquifer.

In this example, BIOMOC was used to evaluate the relative contribution of aerobic and anaerobic biodegradation processes to natural attenuation of a petroleum hydrocarbon plume. Using the model, it was possible to account for the variation in degradation rates between aerobic and anaerobic processes and between different classes of dissolved organic carbon. The model also provided an accounting of each type of electron acceptor and thus could be used to determine when the background supply was exhausted. This section describes how BIOMOC was used to simulate the important degradation processes observed at a crude-oil spill study site. Further details of this example are given by Essaid and others (1995).

\section{Site Description}

On August 20,1979, a buried oil pipeline located in a pitted and dissected glacial outwash plain near Bemidji, Minnesota, broke, spilling about $1.7 \times 10^{6}$ liters (11,000 barrels) of crude oil. An estimated $1.2 \times 10^{6}$ liters $(7,800$ barrels) of the spilled oil were removed by pumping from surface pools, trenching, burning, and excavation of soil (Hult, 1984). The oil collected in topographic depressions and trenched areas where large volumes of oil infiltrated into the subsurface, forming two main bodies of oil floating on the water table. The subsurface oil bodies provide a long-term, continuous source of hydrocarbon components that dissolve in, and are transported with, the flowing ground water.

Evidence for microbial degradation of the petroleum hydrocarbons at the site has been documented in several studies (Lovley and others, 1989; Hult and others, 1991; Hiebert and Bennett, 1992; Bennett and others, 1993; Eganhouse and others, 1993; Baedecker and others, 1993; Cozzarelli and others, 1994; Eganhouse and others, 1996). Five geochemical zones in the ground water (figure 9) have been identified along a section through the northern oil body (Baedecker and others, 1989; Baedecker and others, 1993; Bennett and others, 1993). Zone 1 consists of oxygenated uncontaminated native ground water. The native water is very low in nitrate, ammonia, and sulfate. Zone 2, which is below the area sprayed by oil, is characterized by reduced oxygen concentrations and the presence of refractory high molecular-weight hydrocarbons. Zone 3, beneath and immediately downgradient from the separate-phase oil body, is anoxic and contains high concentrations of hydrocarbons, dissolved manganese and iron, and methane. Zone 4 makes a transition from anoxic conditions to fully oxygenated conditions, where concentrations of hydrocarbons decrease rapidly as a result of aerobic degradation. Zone 5 consists of oxygenated water downgradient from the oil body with slightly elevated concentrations of dissolved inorganic and organic constituents.

Ground-water samples from numerous wells along this section have been analyzed over time (Baedecker and others, 1993; Bennett and others, 1993; Eganhouse and others, 1993). Total dissolved organic carbon (TDOC) is made up of two operationally defined fractions: volatile dissolved organic carbon (VDOC) and nonvolatile dissolved organic carbon (NVDOC) (Baedecker and others, 1993). Figure 10 shows the temporal evolution of concentrations since 1979 at a well located $36 \mathrm{~m}$ downgradient from the center of the oil body. VDOC and NVDOC concentrations initially increased and then achieved steady concentrations. $\mathrm{Mn}^{2+}$ increased, peaking after eight years and then decreased suggesting that the $\mathrm{Mn}$ available for reduction was being depleted. $\mathrm{Fe}^{2+}$ concentrations began to increase after eight years following the drop in $\mathrm{Mn}^{2+}$, and peaked in 11 years, suggesting iron reduction. Likewise methane concentration abruptly increased after eight years and then leveled off suggesting the onset of methanogenesis. 


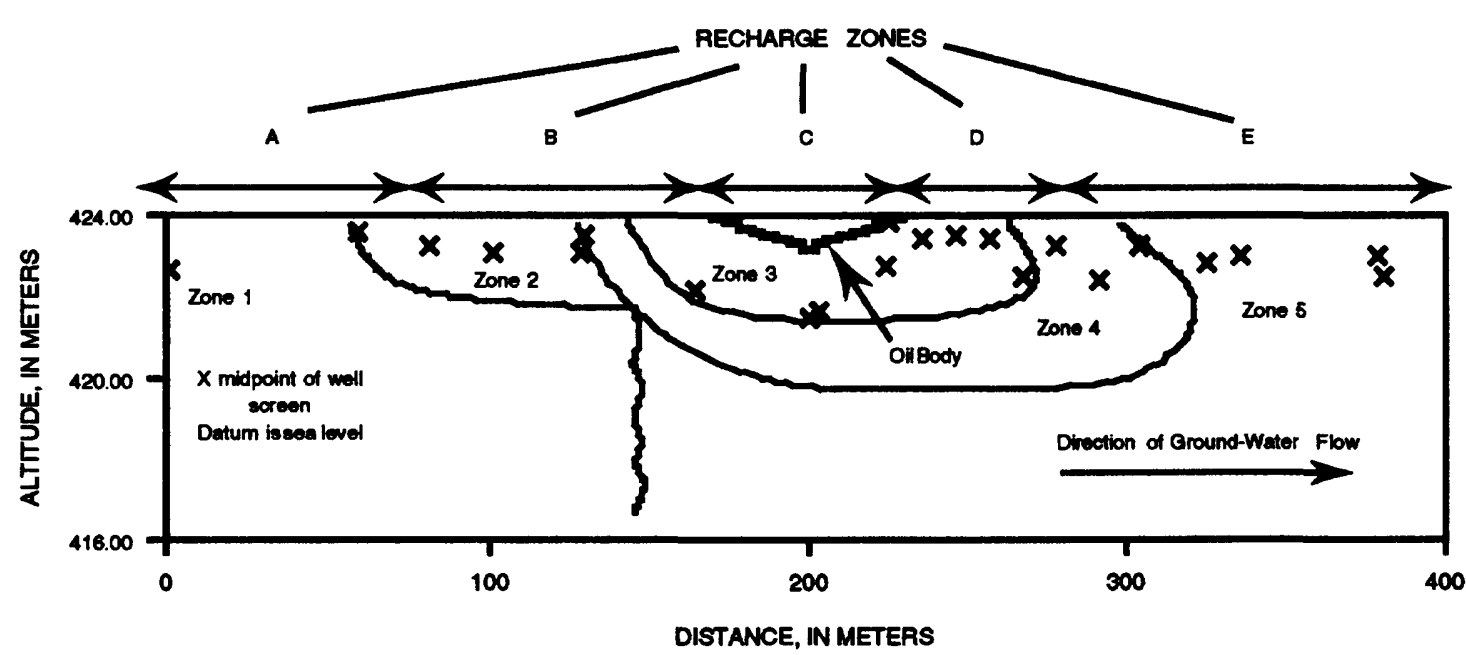

Figure 9. The simulated two-dimensional cross section at the Bemidji, Minnesota, site, showing the recharge zones used in the model simulation (table 12), the discrete representation of the oil body, and the geochemical zones of the ground-water plume: Zone 1 - oxygenated uncontaminated native ground water; Zone 2 - ground water with reduced oxygen concentrations and refractory high molecular weight hydrocarbons; Zone 3 - anoxic ground water with high concentrations of hydrocarbons, dissolved manganese, iron, and methane; Zone 4 - transition from anoxic to fully oxygenated conditions with rapid decrease in concentrations of hydrocarbons; Zone 5 - oxygenated water with slightly elevated concentrations of dissolved inorganic and organic constitutents. (modified from Baedecker and others (1993)).

\section{The Conceptual Model}

Because the field conditions at the Bemidji site are complex, a simplified conceptual model was developed to make the simulations tractable. Seven mobile solutes (VDOC, NVDOC, DO, Nitrogen, $\mathrm{Mn}^{2+}, \mathrm{Fe}^{2+}$, and $\left.\mathrm{CH}_{4}\right)$, two solid-phase concentrations $\left(\mathrm{Mn}^{4+}\right.$ and $\left.\mathrm{Fe}^{3+}\right)$, and three microbial populations (aerobes, $\mathrm{Mn} / \mathrm{Fe}$ reducers, and methanogens) were modeled. Table 11 summarizes the eight biodegradation processes represented in the model and the solutes involved in each process. TDOC was split into two degradable fractions - volatile dissolved organic carbon (VDOC) and nonvolatile dissolved organic carbon (NVDOC). Each DOC fraction undergoes aerobic degradation, $\mathrm{Mn}$ reduction, $\mathrm{Fe}$ reduction, and methanogenesis. The model accounts for the transport and consumption or production of: dissolved oxygen (DO); the cellular nutrient nitrogen $(\mathrm{N})$; dissolved manganese $\left(\mathrm{Mn}^{2+}\right)$ produced by reduction of solid phase manganese $\left(\mathrm{Mn}^{4+}\right)$; dissolved iron $\left(\mathrm{Fe}^{2+}\right)$ produced by reduction of solid phase iron $\left(\mathrm{Fe}^{3+}\right)$; and methane $\left(\mathrm{CH}_{4}\right)$ produced by methanogenesis. Aerobic degradation takes place first, with oxygen noncompetitively inhibiting anaerobic processes. In addition, iron reduction is noncompetitively inhibited by solid phase manganese. Thus, as oxygen is consumed and an anoxic zone develops, the $\mathrm{Mn} / \mathrm{Fe}$ reducers and methanogens begin to grow and release dissolved $\mathrm{Mn}$, dissolved $\mathrm{Fe}$, and methane. The multiple Monod formulation of equation (3) was used because this formulation is more common in the literature than the minimum Monod formulation. 

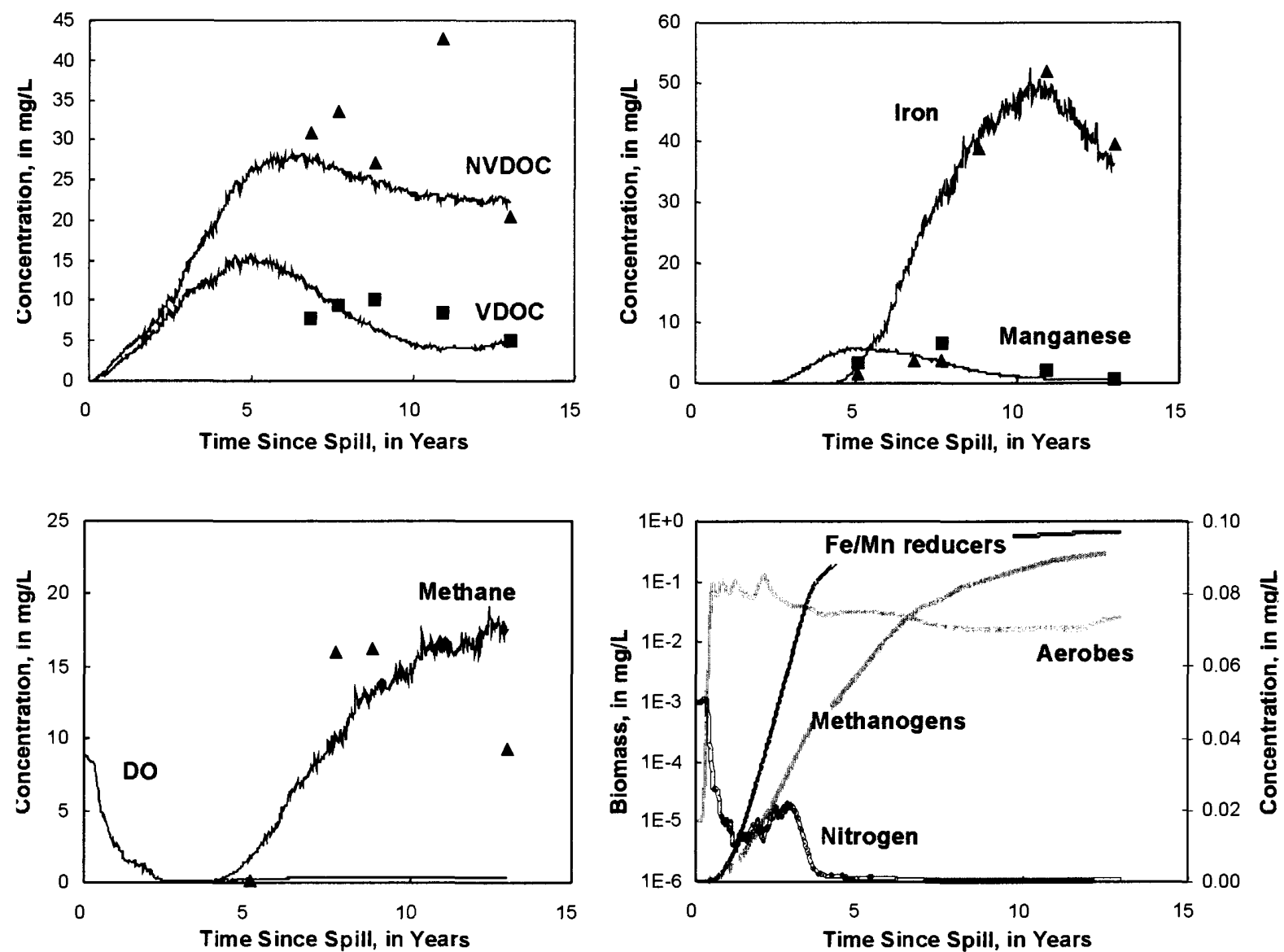

Figure 10. Changes in simulated (lines) and observed (symbols) concentrations with time since 1979 at a location $36 \mathrm{~m}$ downgradient from the center of the oil body: (a) volatile and nonvolatile dissolved organic carbon (VDOC and NVDOC, respectively); (b) dissolved manganese $\left(\mathrm{Mn}^{2+}\right)$ and dissolved iron $\left(\mathrm{Fe}^{2+}\right)$; (c) dissolved oxygen (DO) and methane; and (d) nitrogen, aerobes, $\mathrm{Mn} / \mathrm{Fe}$ reducers, and methanogens.

Table 11.--Biodegradation processes, the solutes involved in each process, and the microbial population responsible for each process in the Bemidji simulation (Aerobic $=$ aerobic biodegradation, $\mathrm{Mn}$ red. $=\mathrm{Mn}$ reduction, $\mathrm{Fe}$ red. $=$ Fe reduction, Meth. $=$ methanogenesis, $\mathrm{X}=$ consumed, $++=$ produced, $\mathrm{I}=$ inhibits, $\mathrm{A}=$ aerobes, $\mathrm{Mn} / \mathrm{Fe}=$ manganese and iron reducers, $\mathrm{M}=$ methanogens).

VDOC:

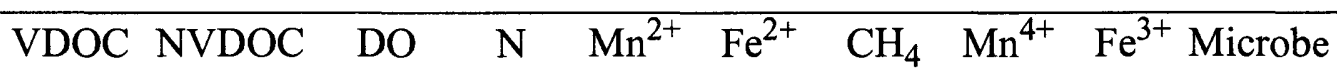

Aerobic $\mathrm{X} \quad \mathrm{X} \quad \mathrm{X}$

Mn red. $\quad \mathrm{X} \quad++\quad \mathrm{I}_{\mathrm{nc}} \mathrm{X}$

Fe red. $\mathrm{X}++\quad \mathrm{I}_{\mathrm{nc}} \mathrm{X}$

Meth. $\mathrm{X}$

NVDOC:

Aerobic

Mn red.

Fe red.

Meth.
$\begin{array}{lll}X & X & X\end{array}$

$\begin{array}{lll}X & I_{n c} & X\end{array}$

$\begin{array}{lll}X & I_{n c} & X\end{array}$

$\begin{array}{lll}X & I_{n c} & X\end{array}$

$\begin{array}{ccccc} & & & & \mathrm{A} \\ & & \mathrm{X} & & \mathrm{Mn} / \mathrm{Fe} \\ & & \mathrm{I}_{\mathrm{nc}} & \mathrm{X} & \mathrm{Mn} / \mathrm{Fe} \\ & ++ & & & \mathrm{M}\end{array}$

A

$\mathrm{Mn} / \mathrm{Fe}$

$\mathrm{X} \mathrm{Mn} / \mathrm{Fe}$

$\mathrm{M}$ 
Table 12.--Initial and recharge water concentration in milligrams per liter for the Bemidji, Minn., example (Recharge zones A through $\mathrm{E}$ are shown in figure 9).

\begin{tabular}{|c|c|c|c|c|c|c|}
\hline \multirow[b]{2}{*}{ Solute } & \multirow{2}{*}{$\begin{array}{c}\text { Initial } \\
\text { Concentration } \\
\mathrm{mg} / \mathrm{L}\end{array}$} & \multirow[b]{2}{*}{ A } & \multicolumn{4}{|c|}{ Recharge Zone Concentration } \\
\hline & & & B & C & D & $E$ \\
\hline VDOC & 0.0 & 0.0 & 0.0 & 70.0 & 0.0 & 0.0 \\
\hline NVDOC & 0.0 & 0.0 & 20.0 & 80.0 & 0.0 & 0.0 \\
\hline DO & 9.0 & 9.0 & 9.0 & 0.0 & 4.5 & 9.0 \\
\hline $\mathrm{N}$ & 0.05 & 0.05 & 0.05 & 0.24 & 0.05 & 0.05 \\
\hline $\mathrm{Mn}^{2+}$ dissolved & 0.0 & 0.0 & 0.0 & 0.0 & 0.0 & 0.0 \\
\hline $\mathrm{Fe}^{2+}$ dissolved & 0.0 & 0.0 & 0.0 & 0.0 & 0.0 & 0.0 \\
\hline Methane & 0.0 & 0.0 & 0.0 & 0.0 & 0.0 & 0.0 \\
\hline $\mathrm{Mn}^{4+}$ solid & 100. & 0.0 & 0.0 & 0.0 & 0.0 & 0.0 \\
\hline $\mathrm{Fe}^{3+}$ solid & 1500. & 0.0 & 0.0 & 0.0 & 0.0 & 0.0 \\
\hline
\end{tabular}

A vertical cross-section of unit width parallel to the direction of ground-water flow along the sampling transect was simulated from the time of the spill in 1979 until September 1992 (figure 9). Steady-state flow and isothermal conditions $\left(9^{\circ} \mathrm{C}\right)$ were assumed. The average organic carbon content of the aquifer is only $0.09 \%$, resulting in retardation factor estimates that lie within the range of uncertainty in the velocity estimates. Therefore, sorption processes were neglected. Also, the change in water-table elevation over time was neglected.

The simulated section ( $8 \mathrm{~m}$ deep, $400 \mathrm{~m}$ wide) is shown in figure 9 . A spatial discretization of 2 $\mathrm{m}$ horizontally and $0.1 \mathrm{~m}$ vertically, and a temporal discretization of 10.3 days were used. Constant heads of $424.0 \mathrm{~m}$ and $422.6 \mathrm{~m}$ were specified at the upgradient and downgradient lateral boundaries, respectively. The bottom boundary condition was no flow, and a temporally constant rate of recharge was specified across the top of the aquifer. Within the oil body, the oil in the pore space reduces the flow of water through this zone. As a first approximation, the hydraulic conductivity and recharge rate were reduced to 25 percent of the aquifer values in the zone of the oil body.

Table 12 lists the initial and recharge water concentrations used for each solute. The initial system was a clean aquifer with fully oxygenated water. The background dissolved organic carbon concentration $(2.0 \mathrm{mg} / \mathrm{L})$ was neglected because it was assumed to be a nondegradable, naturally occurring fraction. The initial solid phase iron concentration was $1,500 \mathrm{mg} / \mathrm{L}$ of bulk aquifer volume (17 mmole/kg sediment) based on a background value measured by Lovley and others (1989) and an initial solid phase $\mathrm{Mn}$ concentration of $100 \mathrm{mg} / \mathrm{L}$ bulk aquifer volume was assumed.

VDOC and NVDOC from the oil body entered the aquifer with the recharge water. In the spray zone (recharge zone B), all of the volatile and some of the nonvolatile components appear to have been degraded in the unsaturated zone (Baedecker and others 1993). The recharge water in the spray zone was assumed to be fully oxygenated, and the observed reduction in DO concentration in the ground water was assumed to be due to aerobic degradation of NVDOC occurring in the saturated zone. In the zone of the oil body (recharge zone $\mathrm{C}$ ), it was assumed that both volatile and nonvolatile carbon fractions entered the aquifer (Eganhouse and others, 1993). Hult and others (1991) have shown that biodegradation above the water table depletes the oxygen resulting in an anoxic unsaturated zone in the vicinity of the oil. Therefore, it was assumed that there was no oxygen in the 
recharge water near the oil body (zone $\mathrm{C}$ ), and that oxygen was partially depleted in the recharge water downgradient of the oil body (zone D). In order to maximize the amount of nitrogen available for cell growth, the total measured nitrogen concentration in the aquifer (nitrate plus ammonia forms) was assumed to be available for cell growth. In the background zones this was $0.05 \mathrm{mg} / \mathrm{L}$. Measured concentrations in the oil zone were much higher than in background water (either due to nitrogen sources in the oil body or from breakdown of biomass) and the recharge water in zone $\mathrm{C}$ was assigned a concentration of $0.24 \mathrm{mg} / \mathrm{L}$.

\section{Model Parameter Estimates}

Most of the transport and biodegradation parameters needed to simulate the Bemidji plume have not been measured at the site. Literature values, theoretical estimates, and field biomass measurements were used to obtain reasonable estimates of parameter values used in the simulation.

\section{Flow and Transport Parameters}

Estimates of permeability (Essaid and others, 1993; Dillard, 1993) and measurements of velocity (White, 1991) have been made at the site; however, the values range over several orders of magnitude. Average values of physical properties obtained from these studies were used in the simulations. The porosity was 0.38 , the hydraulic conductivity was $1 \times 10^{-4} \mathrm{~m} / \mathrm{s}$, the water table gradient was 0.0035 , and the recharge rate was $0.126 \mathrm{~m} / \mathrm{yr}$. These values result in an average linear velocity of $0.09 \mathrm{~m} / \mathrm{d}$. A longitudinal dispersivity of $0.1 \mathrm{~m}$ and a transverse dispersivity of $0.001 \mathrm{~m}$ were assumed.

\section{Biodegradation Kinetics Parameters}

When available, literature values were used to help constrain the model parameters. The literature contains numerous measurements of Monod kinetic parameters for aerobic degradation of hydrocarbons (e.g. MacQuarrie and others, 1990; Alvarez and others, 1991). Reported asymptotic maximum specific uptake rate $\left(V_{\max }\right)$ values range from 0.01 to $9.9 \mathrm{~d}^{-1}$, half saturation constant $(K)$ values range from 0.03 to $15.9 \mathrm{mg} / \mathrm{L}$, and yields $(Y)$ range from 0.01 to $1.56 \mathrm{gm}$ cells $/ \mathrm{gm}$ carbon. Unfortunately, most studies of anaerobic degradation of hydrocarbons have been limited to estimates of first-order biodegradation rates rather than full Monod kinetics parameters (e.g. Wilson and others, 1990; Cozzarelli and others, 1994; Wilson and others, 1994; and Albrechtsen, 1994). Without knowing the biomass concentrations in these experiments, it is impossible to estimate Monod kinetics parameters from these first-order rates. Edwards and Grbić-Galić (1994) reported kinetic parameters for methanogenic degradation of toluene by enriched cultures. Their values, expressed in terms of carbon uptake, were $V_{\max }=0.19 \mathrm{~d}^{-1}, K=0.25 \mathrm{mg} / \mathrm{L}$, and $Y=0.01 \mathrm{gm}$ cells $/ \mathrm{gm}$ carbon.

\section{Yield Estimates}

To limit the range of possible kinetic parameters that could be used in the model, theoretical growth yields for the degradation of benzene, toluene, ethylbenzene, and xylene (BTEX compounds) were computed using the stoichiometric and thermodynamic model presented by McCarty (1971). The computational method is outlined by McFarland and Sims (1991) together with a comment on adjusting the calculations for nonstandard conditions given by Walton and Smith (1992). 
The reaction free energies were first computed using unit activities at a $\mathrm{pH}$ of 7.0. The free energies of formation for water and carbon dioxide were taken from Thauer and others (1977). The aqueous free energies of the BTEX compounds were computed from the gaseous state values given in Reid and others (1985) using values for Henry's constants from Montgomery and Welkom (1990). Reaction stoichiometries and free energies for the electron acceptor half-reactions were taken from McFarland and Sims (1991). The nitrogen source was assumed to be ammonia and because of the highly hostile environment in the field, a low efficiency of energy transfer $(0.2)$ was assumed to be representative of field conditions (Battley, 1987).

\section{Uptake Coefficients}

Data from microcosm studies (Cozzarelli and others, 1994) were used to determine the uptake coefficients for the manganese and iron reduction of hydrocarbons. It was found in this study that only a fraction of the solid phase manganese and iron used by the microbes is released as dissolved $\mathrm{Mn}^{2+}$ and $\mathrm{Fe}^{2+}$. There is field evidence that the rest is precipitated as a solid phase (Baedecker and others, 1992). Eganhouse and others (1993) examined the downgradient profiles of VDOC and NVDOC and concluded that some of the VDOC is being degraded to NVDOC as an intermediate step in the anoxic zone. For this reason, in the model, half of the VDOC that is degraded by $\mathrm{Mn} / \mathrm{Fe}$ reduction is converted to NVDOC $\left(\beta_{\mathrm{NVDOC}}=-0.5\right)$. Stoichiometric relations were used to determine the uptake coefficients for the other biodegradation processes.

\section{Initial Biomass Estimates}

In August, 1994, samples were collected from a background location, and two locations downgradient from the oil body ( 39 and $52 \mathrm{~m}$ from the center of the oil body) for microbial biomass determinations. The Most Probable Number (MPN) method was used to enumerate microorganisms in water and sediment samples capable of degradation under differing redox potentials. In order to obtain estimates of initial concentrations of aerobes, $\mathrm{Mn} / \mathrm{Fe}$ reducers, and methanogens, biomass concentrations were calculated from the MPN numbers assuming a cell dry weight of $2 \times 10^{-10} \mathrm{mg}$ (McCarty, 1985). Background concentrations were on the order of $10^{-5} \mathrm{mg} / \mathrm{L}$ for aerobes, and $10^{-7}$ to $10^{-6} \mathrm{mg} / \mathrm{L}$ for Fe reducers and methanogens (Essaid and others, 1995).

\section{Calibrated Model Results}

Comparisons to the observed spatial and temporal variations in solute concentrations were used to calibrate the model. The yield estimates obtained using an efficiency of 0.2 were used as initial guesses and $V_{\max }$ and $K$ values were adjusted. The parameters used in the model (table 13) were obtained by trial and error adjustment of initial guesses. Table 13 reports the values for VDOC biodegradation kinetics. The parameters for the NVDOC were identical, except that $V_{\max }$ and $Y$ were 75 percent of the values for VDOC. This is based on the observation in the field that the VDOC fraction is degraded more easily than the NVDOC fraction (Eganhouse and others, 1993). Inhibition factors were obtained by calibration. Table 14 lists the section of the BIOMOC input file that specifies the biodegradation parameters to illustrate how the biodegradation processes and parameters of this example are setup in the model input. 
Table 13.--Biodegradation parameters used in the Bemidji, Minn., simulation for VDOC. The parameters for NVDOC are the same except for $V_{\max }$ and $Y$ which are 75 percent of the VDOC values. The footnotes give the basis for the estimates.

Aerobic degradation of VDOC:

$\begin{array}{ll}{ }^{1} V \max & 0.5 \mathrm{~d}-1 \\ { }^{1} K_{V D O C} & 1.0 \mathrm{mg} / \mathrm{L} \\ { }^{1} K_{D O} & 1.0 \mathrm{mg} / \mathrm{L} \\ { }^{2} Y & 0.27 \mathrm{mg} / \mathrm{mg} \\ { }^{3} \beta_{V D O C} & 1.0 \\ { }^{3} \beta_{D O} & 2.6\end{array}$

Manganese reduction of VDOC:

$\begin{array}{ll}{ }^{1} V_{\max } & 0.065 \mathrm{~d}-1 \\ { }^{1} K_{V D O C} & 1.0 \mathrm{mg} / \mathrm{L} \\ { }^{1} K_{M n^{4+}} & 15 \mathrm{mg} / \mathrm{L} \\ { }^{2} Y & 0.21 \mathrm{mg} / \mathrm{mg} \\ { }^{4} k_{n c D O} & 0.8 \mathrm{mg} / \mathrm{L} \\ { }^{3} \beta_{V D O C} & 1.0 \\ { }^{3} \beta_{N V D O C} & -0.5 \\ { }^{3} \beta_{M n^{4+}} & 12 . \\ { }^{3} \beta_{M n^{2+}} & -2.1\end{array}$

Iron reduction of $\mathrm{VDOC}$ :

\begin{tabular}{|c|c|}
\hline & $0065 d-1$ \\
\hline${ }^{1} K_{V D O C}$ & $1.0 \mathrm{mg} / \mathrm{L}$ \\
\hline${ }^{1} K_{\mathrm{Fe}^{3+}}$ & $50 \mathrm{mg} / \mathrm{L}$ \\
\hline${ }^{2} Y$ & $0.063 \mathrm{mg} / \mathrm{mg}$ \\
\hline${ }^{4} k_{n c D} O$ & $0.8 \mathrm{mg} / \mathrm{L}$ \\
\hline${ }^{4} k_{n c M n^{4+}}$ & $0.001 \mathrm{mg} / \mathrm{L}$ \\
\hline${ }^{3} \beta_{V D O C}$ & 1.0 \\
\hline${ }^{3} \beta_{N V D O C}$ & -0.5 \\
\hline${ }^{3} \beta_{F e}{ }^{3+}$ & 24. \\
\hline${ }^{3} \beta_{\mathrm{Fe}^{2+}}$ & -4.3 \\
\hline
\end{tabular}

Methanogenic degradation of VDOC:

Microbial Populations:

$\begin{array}{ll}{ }^{1} V_{\max } & 0.19 \mathrm{~d}-1 \\ { }^{1} K_{V D O C} & 0.25 \mathrm{mg} / \mathrm{L} \\ { }^{2} Y & 0.03 \mathrm{mg} / \mathrm{mg} \\ { }^{4} k_{n c D O} & 0.8 \mathrm{mg} / \mathrm{L} \\ { }^{3} \beta_{V D O C} & 1.0 \\ { }^{3} \beta_{C H 4} & -0.83\end{array}$

Nitrogen uptake:

${ }^{1} K_{\text {nut }} \quad 0.001 \mathrm{mg} / \mathrm{L}$

$\begin{array}{llll} & \text { Aerobes } & \mathrm{Mn} / \mathrm{Fe} \text { Reducers } & \text { Methanogens } \\ { }^{4} k_{b i o} \mathrm{mg} / \mathrm{L} & 0.35 & 0.35 & 0.30 \\ { }^{5} X_{o} \mathrm{mg} / \mathrm{L} & 0.00001 & 0.000001 & 0.000001 \\ { }^{1} d_{k} \mathrm{~d}^{-1} & 0.02 & 0.0002 & 0.0\end{array}$

1. Initial guesses based on reported literature values, with adjustment during calibration.

2. Based on yield estimate calculations.

3. Based on stoichiometry and results of microcosm experiments.

4. Calibrated.

5. Based on field measurements. 
Table 14.--Biodegradation parameters, and their description, from the BIOMOC input file for the Bemidji, Minn., simulation. Solutes one through nine are: volatile- and nonvolatile-dissolved organic carbon (VDOC and NVDOC), dissolved oxygen, nitrogen, dissolved manganese, dissolved iron, methane, solid phase manganese, and solid phase iron, respectively. Microbial populations one through three are: aerobes, manganese/iron reducers, and methanogens, respectively. Biodegradation processes one through eight are: aerobic degradation of VDOC; manganese reduction, iron reduction, and methanogenesis coupled to oxidation of VDOC; aerobic degradation of NVDOC; manganese reduction, iron reduction, and methanogenesis coupled to oxidation of NVDOC, respectively. (is is an index for solutes involved in a particular biodegradation process, $k s$ is an index for all solutes simulated, $i b$ is an index for microbial population, $n c$ is an index for all solutes acting with a given inhibition type on a biodegradation proces, other parameters are defined in Appendix B)

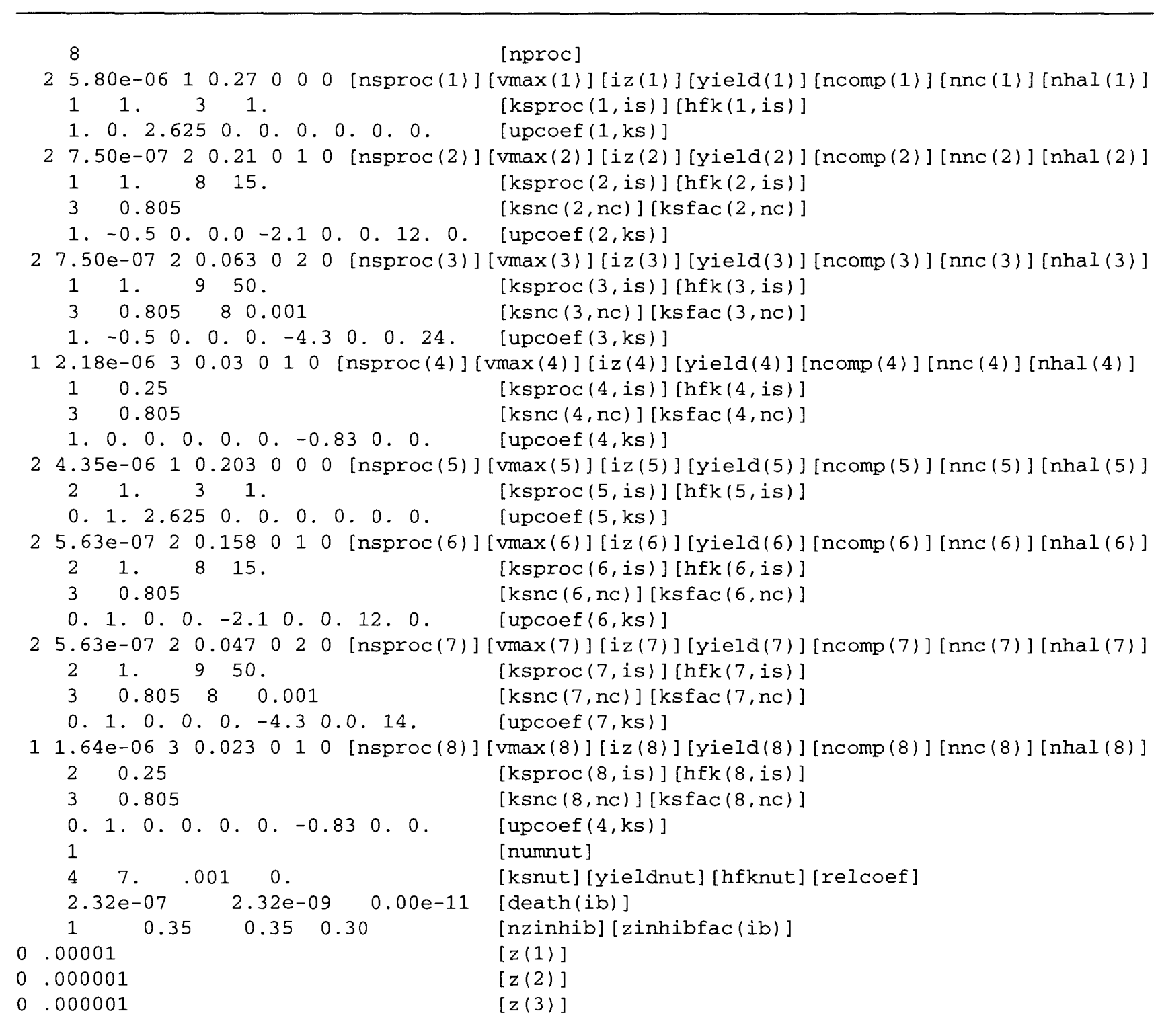


Figure 10 presents the observed and simulated concentrations at a well that is $36 \mathrm{~m}$ downgradient from the center of the oil body. The observed and simulated VDOC and NVDOC concentrations match quite well (figure 10a). The temporal variation in $\mathrm{DO}, \mathrm{Mn}^{2+}, \mathrm{Fe}^{2+}$, and methane concentrations are shown in figures $10 \mathrm{~b}$ and $10 \mathrm{c}$. The simulation captures the general evolution of the plume with time, but does not match the observed concentrations exactly. Figure 10d shows the influence of nutrient limitation on biomass growth. At early time, there is considerable growth of aerobic biomass with a rapid decrease in nitrogen concentrations as the nitrogen is incorporated into the new biomass. As aerobic biomass growth slows, due to biomass inhibition, the uptake of nitrogen is less than the influx of nitrogen, and the nitrogen concentration increases. Then, as $\mathrm{Mn} / \mathrm{Fe}$ reducers and methanogens begin to grow substantially, the nitrogen concentration drops and eventually approaches $0 \mathrm{mg} / \mathrm{L}$. This causes a slowing in the biomass growth because of the limited influx of nitrogen, in addition to slowing of growth by biomass inhibition.

\section{CONCLUSIONS}

The model described in this report can simulate the two-dimensional transport and biotransformation of multiple reacting solutes. The program is general and flexible allowing for any combination of electron donor and acceptor species. A number of mathematical expressions for biological transformation rates from the literature have been included as options in the code. These include single, multiple, and minimum Monod kinetics and competitive, noncompetitive, and substrate inhibition. The inhibition formulations are particularly useful for modeling the transitions between redox zones within contaminant plumes. The kinetic parameters can be formulated to simulate zero-order or first-order approximations to Monod kinetics. The growth and decay of several microbial populations performing the transformations is also accounted for. The microbial growth can be either disabled, limited by a prescribed maximum value, or limited by the availability of a specified nutrient.

The accuracy of the numerical results has been evaluated by comparison with analytical solutions and with other numerical codes. In these cases there was good agreement between the BIOMOC results and the other solution methods. The code has been applied to two example problems. The first example is a one-dimensional steady-state simulation of the transformation of chlorinated solvents. The second example is a two-dimensional transient simulation of a crude-oil spill site. The descriptions of these examples serve as useful illustrations of the steps involved in formulating a conceptual model and assembling the many input parameters. 


\section{REFERENCES}

Albrechtsen, J.J., 1994, Bacterial degradation under iron-reducing conditions, in Hinchee, R.E., Alleman, B.C., Hoeppel, R.E., and Miller, R.N. (editors), Hydrocarbon Bioremediation: Lewis Publishers, Boca Raton, Florida, p. 418-423.

Alvarez, P.J.J., Anid, P.J., and Vogel, T.M., 1991, Kinetics of aerobic biodegradation of benzene and toluene in sandy aquifer material: Biodegradation, v. 2, p. 43-51.

Baedecker, M.J. and Back, W., 1979, Hydrogeological processes and chemical reactions at a landfill: Ground Water, v. 17, p. 429-437.

Baedecker, M.J., Cozzarelli, I.M., Evans, J.R., and Hearn, P.P., 1992, Authogenic mineral formation in aquifers rich in organic material, in Kharaka, Y.K. and Maest, A.S. (editors), Seventh International Symposium on Water-Rock Interaction, Proceedings: Balkema, Rotterdam, p. 257261.

Baedecker, M.J., Cozzarelli, I.M., Siegel, D.I., Bennett, P.C., and Eganhouse, R.P., 1993, Crude oil in a shallow sand and gravel aquifer-III. Biogeochemical reactions and mass balance modeling in anoxic ground water: Applied Geochemistry, v. 8, p. 569-586.

Baedecker, M.J., Siegel, D.I., Bennett, P.C., and Cozzarelli, I.M., 1989, The fate and effects of crude oil in a shallow aquifer I. The distribution of chemical species and geochemical facies, in G.E. Mallard, G.E. and S.E. Ragone, S.E. (editors), U.S. Geological Survey Toxic Substances Hydrology Program-Proceedings of the Technical Meeting, Phoenix, Arizona, September 2630, 1988, Water-Resources Investigations Report 88-4220, p. 13-20.

Battley, E.H., 1987, Energetics of microbial growth: John Wiley and Sons, New York, p. 410-416.

Baveye, P., and Valocchi, A., 1989, An evaluation of mathematical models of the transport of biologically reacting solutes in saturated soils and aquifers: Water Resources Research, v. 25, no. 6, p. 1413-1421.

Bennett, P.C., Siegel, D.I., Baedecker, M.J., and Hult, M.F., 1993, Crude oil in a shallow sand and gravel aquifer-I. Hydrogeology and inorganic geochemistry: Applied Geochemistry, v. 8, p. 529-549.

Borden, R.C., Bedient, P.B., Lee, M.D., Ward, C.H., and Wilson, J.T., 1986, Transport of dissolved hydrocarbons influenced by oxygen-limited biodegradation, 2. Field application: Water Resources Research, v. 22, no. 13, p. 1983-1990.

Bouwer, E.J., and Zehnder, A.J.B., 1993, Bioremediation of organic compounds-putting microbial metabolism to work: Trends in Biotechnology, v. 11, p. 360-367.

Celia, M.A., Kindred, J.S., and Herrera, I., 1989, Contaminant transport and biodegradation 1. A numerical model for reactive transport in porous media: Water Resources Research, v. 25, no. 6, p. 1141-1148.

Chapelle, F.H. and Lovley, D.R., 1992, Competitive exclusion of sulfate-reduction by $\mathrm{Fe}(\mathrm{III})-$ reducing bacteria: A mechanism for producing discrete zones of high-iron ground water: Ground Water, v. 30, no. 1, p. 29-36.

Chen, Y.M., Abriola, L.M., Alvarez, P.J.J., Anid, P.J., and Vogel, T.M., 1992, Modeling transport and biodegradation of benzene and toluene in sandy aquifer material: Comparisons with experimental measurements: Water Resources Research, v. 28, no. 7, p. 1833-1847.

Chiang, C.J., Salanitro, J.P., Chai, E.Y., Colthart. J.D., and Klein, C.L., 1989, Aerobic biodegradation of benzene, toluene, and xylene in a sandy aquifer-Data analysis and computer modeling: Ground Water, v. 27, no. 6, p. 823-834. 
Cozzarelli, I.M., Baedecker, M.J., Eganhouse, R.P., and Goerlitz, D.F., 1994, Geochemical evolution of low-molecular-weight organic acids derived from the degradation of petroleum contaminants in groundwater: Geochimica Cosmochimica Acta, v. 58, no. 2, p. 863-877.

Davis, J.W. and Carpenter, C.L., 1990, Aerobic biodegradation of vinyl chloride in groundwater samples: Applied Environmental Microbiology, p. 56, no. 12, p. 3878-3880.

Dillard, L.A., 1993, Multiphase flow modeling of a crude-oil spill site using geostatistical simulation of soil hydraulic properties: M.S. Thesis, Stanford University, Stanford, California.

Edwards, E.A., and Grbić-Galić, D., 1994, Anaerobic degradation of toluene and o-xylene by a methanogenic consortium: Applied and Environmental Microbiology, v. 60, no. 1, p. 313-322.

Eganhouse, R.P., Baedecker, M.J., Cozzarelli, I.M., Aiken, G.R., Thorn, K.A., and Dorsey, T.F., 1993, Crude oil in a shallow sand and gravel aquifer-II. Organic geochemistry: Applied Geochemistry, v. 8, p. 551-567.

Eganhouse, R.P., Dorsey, T.F., Phinney, C.S., and Westcott, A.M., 1996, Processes affecting the fate of monoaromatic hydrocarbons in an aquifer contaminated by crude oil: Environmental Science and Technology, v. 30, no. 11, p. 3304-3312.

Essaid, H.I., Herkelrath, W.N., and Hess, K.M., 1993, Simulation of fluid distributions observed at a crude-oil spill site incorporating hysteresis, oil entrapment, and spatial variability of hydraulic properties: Water Resources Research, v. 29, no. 6, p. 1753-1770.

Essaid, H.I., Bekins, B.A., Godsy, E.M., Warren, E., Baedecker, M.J., and Cozzarelli, I.M., 1995, Simulation of aerobic and anaerobic biodegradation processes at a crude-oil spill site: Water Resources Research, v. 31, no. 12, p. 3309-3327.

Goode, D.J., and Konikow, L.F., 1989, Modification of a method-of-characteristics solute-transport model to incorporate decay and equilibrium-controlled sorption or ion exchange: U.S. Geological Survey Water-Resources Investigations Report 89-4030.

Haldane, J.B.S., 1930, Enzymes: Longmans, Green, New York, p. 84-85.

Hiebert, F.K., and Bennett, P.C., 1992, Microbial control of silicate weathering in organic-rich ground water: Science, v. 258, p. 278-281.

Hult, M.F., 1984, Ground-water contamination by crude oil at the Bemidji, Minnesota, research site-An introduction, in Hult, M.F. (editor), Ground-water contamination by crude oil at the Bemidji, Minnesota, research site: U.S. Geological Survey Water-Resources Investigations Report 84-4188, p. 1-15.

Hult, M.F., Landon, M.K., and Pfannkuch, H.O., 1991, Field validation of conceptual models of mobilization and transport of volatile petroleum derivatives in the unsaturated zone near Bemidji, Minnesota, in Mallard, G.E., and Aronson, D.A. (editors), U.S. Geological Survey Toxic Substances Hydrology Program-Proceedings of the technical meeting, Monterey, California, March 11-15, 1991: U.S. Geological Survey Water-Resources Investigations Report 91-4034, p. 621-626.

Kindred, J.S., and Celia, M.A., 1989, Contaminant transport and biodegradation, 2. Conceptual model and test simulations: Water Resources Research, v. 26, no. 6, p. 1149-1160.

Klier, N.J., West, R.J., and Donberg, P.A., in press, Aerobic biodegradation of dichloroethylenes in surface and subsurface soils, Chemosphere.

Konikow, L.F., and Bredehoeft, J.D., 1978, Computer model of two-dimensional solute transport and dispersion in ground water: U.S. Geological Survey, Techniques of Water-Resources Investigations, Book 7, Chap. C2. 
Lee, M.D., Thomas, J.M., Borden, R.C., Bedient, P.B., Ward, C.H., and Wilson, J.T., 1988, Biorestoration of aquifers contaminated with organic compounds: CRC Crit. Rev. Environ. Control, v. 18 , no. 1, p. 29-89.

Lovley, D.R., Baedecker, M.J., Lonergan, D.J., Cozzarelli, I.M., Phillips, E.J.P., and Siegel, D.I., 1989, Oxidation of aromatic contaminants coupled to microbial iron reduction: Nature, v. 339, p. 297-299.

Lyngkilde, J., and Christensen, T.H., 1992, Redox zones of a landfill leachate pollution plume (Vejen, Denmark): Journal of Contaminant Hydrology, v. 10, p. 273-289.

Macdonald, J.A., and Kavanaugh, M.C., 1994, Restoring contaminated groundwater: An achievable goal?: Environmental Science and Technology, v. 28, no. 8, p. 362A-368A.

MacQuarrie, K.T.B., Sudicky, E.A., and Frind, E.O., 1990, Simulation of biodegradable organic contaminants in groundwater: 1 . Numerical formulation in principal directions: Water Resources Research, v. 26, no. 2, p. 207-222.

Madsen, E.L., 1991, Determining in situ biodegradation: Facts and challenges: Environmental Science and Technology, v. 25, no. 10, p. 1663-1673.

McCarty, P.L., 1971, Energetics and bacterial growth, in Faust, S.D. and Hunter, J.V. (editors), Organic compounds in aquatic environments: Marcel Dekker, New York, p. 495-531.

McCarty, P.L., 1985, Application of biological transformations in ground water: Proceedings, Second International Conference on Groundwater Quality Research, Oklahoma State University, Stillwater, Oklahoma.

McCarty, P.L. and Wilson, J.T., 1992, Natural anaerobic treatment of a TCE plume: St. Joseph, Michigan, NPL Site: Bioremediation of Hazardous Wastes, Environmental Protection Agency, EPA/600/R-92/126, p. 47-50.

McFarland, M.J., and Sims, R.C., 1991, Thermodynamic framework for evaluating PAH degradation in the subsurface: Ground Water, v. 29, p. 885-896.

Molz, F.J., Widdowson, M.A., and Benefield, L.D., 1986, Simulation of microbial growth dynamics coupled to nutrient and oxygen transport in porous media: Water Resources Research, v. 22, no. 8 , p. $1207-1216$.

Monod, J., 1949, The growth of bacterial cultures: Annu. Rev. Microbiol., v. 3, p. 371-394.

Montgomery, J.H., and Welkom, L.M., Groundwater chemicals desk reference: Lewis Publishers, Inc., Chelsea, Michigan.

Parlange, J.Y., Starr, J.L., Barry, D.A., and Braddock, R.D., 1984, Some approximate solutions of the transport equation with irreversible reactions: Soil Science Society of America Journal, v. 137, no. 6, p. 434-442.

Reid, R.C., Prausnitz, J.M., and Poling, B.E.,1985, The properties of gases and liquids: McGraw-Hill, New York.

Rifai, H.S., Bedient, P.B., Wilson, J.T., Miller, K.M., and Armstrong, J.M., 1988, Biodegradation modeling at aviation fuel spill site: Journal of Environmental Engineering, v. 114, no. 5, p. $1007-$ 1029.

Salanitro, J.P., 1993, The role of bioattenuation in the management of aromatic hydrocarbon plumes in aquifers: Ground Water Monitoring Review, v. 13, no. 4, p. 150-161.

Sanford, W.E., and Konikow, L.F., 1985, A two-constituent solute-transport model for ground water having variable density: U.S. Geological Survey Water-Resources Investigations Report 854279.

Segel, I.H., 1975, Enzyme kinetics: John Wiley \& Sons, Inc., New York, New York. 
Selim, H.M., and Mansell, R.S., 1976, Analytical solution of the equation for transport of reactive solute: Water Resources Research, v. 12, p. 528-532.

Semprini, L., Hopkins, G.D., Roberts, P.V., Grbić-Galić, D., and McCarty, P.L., 1991, A field evaluation of in-situ biodegradation of chlorinated ethenes: Part 3, studies of competitive inhibition: Ground Water, v. 29, p. 239-250.

Thauer, R.K., Jungermann, K., and. Decker, K, 1977, Energy conservation in chemotrophic anaerobic bacteria: Bacteriol. Rev., v. 41, p. 110-180.

Thierrin, J., Davis, G.B., Barber, C., Patterson, B.M., Pribac, F., Power, T.R., and Lambert, M., 1993, Natural degradation rates of BTEX compounds and naphthalene in a sulphate reducing groundwater environment: Hydrological Sciences Journal, v. 38, no. 4, p. 309-322.

U.S. Army Corps of Engineers and Dames and Moore, 1994, Remedial investigation north and east management units Dover Air Force Base, Dover, Delaware, Volume III: AMC Project Number FJTX927000.

van Genuchten, M. Th., and Alves, W.J., 1982, Analytical solutions of the one-dimensional convective-dispersive solute transport equations: U.S. Department of Agriculture Technical Bulletin 1661, $151 \mathrm{p}$.

Vogel, T.M. and McCarty, P.L., 1985, Biotransformation of tetrachloroethylene to trichloroethylene, dichloroethylene, vinyl chloride and carbon dioxide under methanogenic conditions: Applied and Environmental Microbiology, v. 49, p. 1080-1083.

Vogel, T.M., Criddle, C.S., and McCarty, P.L., 1987, Transformation of halogenated aliphatic compounds: Environmental Science and Technology, v. 21, p. 722-736.

Vroblesky, D.A., and Chapelle, F.H., 1994, Temporal and spatial changes of terminal electronaccepting processes in a petroleum hydrocarbon-contaminated aquifer and the significance for contaminant biodegradation: Water Resources Research, v. 30, no. 5, p. 1561-1570.

Walton, J.C., and Smith, R.W., 1992, Discussion of "Thermodynamic framework for evaluating PAH degradation in the subsurface," by M.J. McFarland and R.C. Sims: Ground Water, v. 30, no. 4, p. 624-625.

White, D.L., 1991, Point dilution method determination of groundwater velocities at the Bemidji research site: Unpublished M.A. Thesis, University of Texas, Austin, Texas.

Widdowson, M.A., 1991, Comments on "An evaluation of mathematical models of the transport of biologically reacting solutes in saturated soils and aquifers" by Philippe Baveye and Albert Valocchi: Water Resources Research, v. 27, no. 6, p. 1375-1378.

Widdowson, M.A., 1991, Comments on "An evaluation of mathematical models of the transport of biologically reacting solutes in saturated soils and aquifers" by Philippe Baveye and Albert Valocchi: Water Resources Research, v. 27, no. 6, p. 1375-1378.

Wiedemeier, T.H., Wilson, J.T., and Kampbell, D.H., 1996, Natural attenuation of chlorinated aliphatic hydrocarbons at Plattsburgh Air Force Base, New York, in Symposium on natural attenuation of chlorinated organics in ground water, Sept. 11-13, Dallas, TX, EPA/540/R-96/509, p. 74-82.

Wilson, J.T., Kampbell, D.H., and Armstrong, J., 1994, Natural bioreclamation of alkylbenzenes (BTEX) from a gasoline spill in methanogenic ground water, in Hinchee, R.E., Alleman, B.C., Hoeppel, R.E., and Miller, R.N. (editors), Hydrocarbon Bioremediation: Lewis Publishers, Boca Raton, Florida, p. 418-423. 


\section{APPENDIX A: NOTATION}

$b \quad$ thickness of aquifer or width of the vertical cross-section through the aquifer, $\mathrm{L}$.

$B_{i} \quad$ biodegradation reaction term, $\mathrm{ML}^{-3} \mathrm{~T}^{-1}$.

$C_{i} \quad$ concentration of the $i$ th solute, $\mathrm{ML}^{-3}$.

$C_{i}^{\prime} \quad$ concentration of the $i$ th solute in the source fluid, $\mathrm{ML}^{-3}$.

$C^{*}{ }_{i} \quad$ new concentration at each model block resulting from advective transport, $\mathrm{ML}^{-3}$.

$C_{n u t}$ concentration of a nutrient, $\mathrm{ML}^{-3}$.

$C_{o} \quad$ total solution concentration of two exchanging ions, $\mathrm{L}^{-3}$.

$D_{j k} \quad$ dispersion tensor, $\mathrm{L}^{2} \mathrm{~T}^{-1}$.

$d_{k}$

$H_{s}$

death rate or maintenance constant, $\mathrm{T}^{-1}$.

$I_{b}$

$I_{c}$

$I_{h}$

$I_{n c}$

$K^{n}$

$k_{b i o}$

$k_{c}$

$k_{h}$

$k_{n c}$

$\mathrm{K}_{\mathrm{d}}$

$K_{z}$

$k_{n c}$

$K_{n u t}$

$k_{s}$

$m$

$P_{k}$

$Q_{\mathrm{s}}$

$R_{i}$

head in aquifer overlying confining layer, $\mathrm{L}$.

biomass inhibition factor, dimensionless.

competitive inhibition factor, dimensionless.

Haldane inhibition factor, dimensionless.

noncompetitive inhibition factor, dimensionless.

half-saturation constant, $\mathrm{ML}^{-3}$.

biomass inhibition constant, $\mathrm{ML}^{-3}$.

competitive inhibition constant, $\mathrm{ML}^{-3}$.

Haldane inhibition constant, $\mathrm{ML}^{-3}$.

noncompetitive inhibition constant, $\mathrm{ML}^{-3}$.

linear sorption distribution coefficient, $\mathrm{L}^{3} \mathrm{M}^{-1}$.

Vertical hydraulic conductivity of confining layer, $\mathrm{LT}^{-1}$.

noncompetitive inhibition constant, $\mathrm{ML}^{-3}$.

half saturation constant for a nutrient, $\mathrm{ML}^{-3}$.

inhibition constant for substance $s, \mathrm{ML}^{-3}$.

thickness of confining layer, $\mathrm{L}$.

specific rate of production of population $k$ biomass, $\mathrm{T}^{-1}$.

concentration of inhibiting substance $s, \mathrm{ML}^{-3}$.

retardation factor for the ith solute, dimensionless.

time, $\mathrm{T}$.

$t_{1 / 2} \quad$ first-order decay half-life, in seconds, $\mathrm{T}$.

$V_{j}$ average linear velocity of the fluid, $\mathrm{LT}^{-1}$.

$V_{\text {max }}^{n}$

maximum specific uptake rate of substrate for biodegradation process $n, \mathrm{~T}^{-1}$.

$W \quad$ source fluid flux, $\mathrm{LT}^{-1}$.

$x_{j} \quad$ spatial coordinate, $\mathrm{L}$.

$X_{k}^{n}$

$X_{o}$

$Y$

$Y_{n u t}$

$\beta_{i}^{n}$

$\Gamma_{n u t}$

$\Delta t$ biomass concentration of microbial population $k$ performing degradation process $n, \mathrm{ML}^{-3}$. initial biomass concentration, $\mathrm{ML}^{-3}$. cell-yield coefficient, $M$ cells/M substrate. cell-yield coefficient of a nutrient, $\mathrm{M}$ bacteria/ $\mathrm{M}$ nutrient.

uptake coefficient of solute $i$ for biodegradation process $n$, dimensionless.

nutrient release coefficient, dimensionless.

time step size, $\mathrm{T}$. 
$\varepsilon \quad$ effective porosity, dimensionless.

$v_{n u t} \quad$ nutrient uptake rate, $\mathrm{ML}^{-3} \mathrm{~T}^{-1}$.

$v^{n} \quad$ uptake rate of substrate by biodegradation process $n, \mathrm{ML}^{-3} \mathrm{~T}^{-1}$.

$\rho_{b} \quad$ aquifer bulk density, $\mathrm{ML}^{-3}$. 


\section{APPENDIX B: DEFINITION OF SELECTED PROGRAM VARIABLES}

AAQ

ANFCTR

AOPT

AREA

BETA

BIOUP

CELDIS

CLKCN

CMSIN

CMSOUT

CNCNC

CNCPCT

CNOLD

CNREC

CNRECH

COMPINHIB

CONC

CONINT

CPROF

C1

DALN

DDRW

DEATH

DELQ

DELS

DERH

DISP

DISTX

DISTY

DK

DLTRAT

DTRN

FACCOMP

FACHAL

FACNC

FCTR

FLMIN

FLMOT

GRDX

GRDY

GROW

HALINHIBFAC $\mathrm{HC}$ area of aquifer in model

anisotropy factor (ratio of $T_{y y}$ to $T_{x x}$ )

iteration parameters

area of one cell in finite-difference grid

longitudinal dispersivity of porous medium

biodegradation reaction term, $B_{i}$

maximum distance across one cell that a particle is permitted to move in one step

(as fraction of width of cell)

concentration of leakage through confining layer or streambed

mass of solute recharged into aquifer

mass of solute discharged from aquifer

change in concentration due to dispersion and sources

change in concentration as percentage of concentration at node

concentration at node at end of previous time increment

concentration of well withdrawal or injection, $C^{\prime}{ }_{i}$

concentration in fluid source

competitive inhibition factor, $I_{c}$

concentration in aquifer at node

concentration in aquifer at start of simulation

concentration profile at water table

CONC at node (IX,IY)

longitudinal dispersion coefficient

drawdown

death rate or maintenance constant, $d_{k}$

volumetric rate of leakage across a confining layer or streambed

rate of change in ground-water storage

change in head with respect to time

dispersion equation coefficients

distance particle moves in $\mathrm{x}$-direction during time increment

distance particle moves in y-direction during time increment

linear sorption distribution coefficient, $K_{d}$

ratio of transverse to longitudinal dispersivity

transverse dispersion coefficient

competitive inhibition constant, $\mathbf{k}_{\mathrm{c}}$

Haldane inhibition constant

noncompetitive inhibition constant, $k_{n c}$

multiplication or conversion factor

solute mass entering modeled area during time step

solute mass leaving modeled area during time step

hydraulic gradient in $\mathrm{x}$-direction

hydraulic gradient in y-direction

specific rate of production of population $k$ biomass, $P_{k}$

haldane inhibition factor

head from column computation 


\begin{tabular}{|c|c|}
\hline HFK & half-saturation constant, $K^{n}$ \\
\hline HFKNUT & half saturation constant for a nutrient, $K_{n u t}$ \\
\hline HI & initial head in aquifer \\
\hline $\mathrm{HK}$ & computed head at end of time step \\
\hline HMIN & minimum iteration parameter \\
\hline HR & $\begin{array}{l}\text { head from row computation in subroutine ITERAT; elsewhere HR represents head } \\
\text { from previous time step }\end{array}$ \\
\hline IBIO & biodegradation flag \\
\hline $\mathrm{IMOB}()$ & particle mobility flag \\
\hline IMOV & particle movement step number \\
\hline INT & pumping period number \\
\hline IPRNT & print control index for hydrographs \\
\hline IREACT & reaction type specifier \\
\hline ITMAX & maximum permitted number of iteration \\
\hline IXOBS & $\mathrm{x}$-coordinate of observation point \\
\hline IYOBS & $y$-coordinate of observation point \\
\hline IZ & index of microbe population involved in biodegradation process \\
\hline KOUNT & iteration number \\
\hline KP & particle set index \\
\hline KPS & particle set solute index \\
\hline $\mathrm{KS}$ & solute index \\
\hline KSCOMP & number of solutes competitively inhibiting a biodegradation process \\
\hline KSHAL & number of solutes causing Haldane inhibition of a biodegradation process \\
\hline KSNC & number of solutes noncompetitively inhibiting a biodegradation process \\
\hline KSNUT & nutrient solute index \\
\hline KSPROC & index for solutes involved in a biodegradation process \\
\hline LIMBO & array for temporary storage of particles \\
\hline $\mathrm{N}$ & time step number \\
\hline NCA & number of aquifer nodes in model \\
\hline NCINHIB & noncompetitive inhibition factor, $I_{n c}$ \\
\hline NCODES & number of node identification codes \\
\hline NCOMP & number of solutes competitively inhibiting a biodegradation process \\
\hline NCONC & number of solutes per particle set \\
\hline NHAL & number of solutes causing Haldane inhibition of a biodegradation process \\
\hline NITP & number of iteration parameters \\
\hline NMOV & number of particle movements (or time increments) required to complete time step \\
\hline NNC & number of solutes noncompetitively inhibiting a biodegradation process \\
\hline NODEID & node identification code \\
\hline $\mathrm{NP}$ & total number of active particles in grid \\
\hline NPCELL & number of particles in a cell during time increment \\
\hline NPMAX & maximum number of available particles \\
\hline NPMP & number of pumping periods or simulation periods \\
\hline NPNT & number of time steps between printouts \\
\hline NPOP & number of microbe populations \\
\hline NPROC & number of biodegradation processes \\
\hline NPSET & number of particle sets \\
\hline
\end{tabular}


NPTPND

NREC

NSOL

NSPROC

NTIM

NTIME

NUMNUT

NUMOBS

NX

NY

NZCRIT

NZERO

PARAM

PART

PARTXY

PERM

PINT

POROS

PUMP

PYR

QNET

QSTR

REC

$\mathrm{RECH}$

RELCOEF

RF

$\mathrm{RN}$

RHOB

RP

S

SLEAK

STORM

STORMI

SUMC

SUMIO

SUMT

SUMTCH

TDEL

THALF

THCK

TIM

TIMD

TIMY initial number of particles per node

number of pumping wells

number of solutes

number of solutes involved in a biodegradation process

number of time steps

time for water table profile

number of nutrients

number of observation wells

number of nodes in $\mathrm{x}$-direction

number of nodes in $y$-direction

maximum number of cells that can be void of particles

number of cells that are void of particles at the end of a time increment

iteration parameter for current iteration

concentration of solutes associated with particle set.

particle $\mathrm{x}$ - and $\mathrm{y}$-coordinates. Also note that the signs of coordinates are used as flags to store information on original location of particle.

hydraulic conductivity

pumping period in years

effective porosity, $\varepsilon$

cumulative net pumpage

total duration of pumping period (in seconds)

net water flux

cumulative change in volume of water in storage

point source or sink; negative for injection, positive for withdrawal, $W$

diffuse recharge or discharge; negative for recharge, positive for discharge

nutrient release coefficient, $\Gamma_{n u t}$

retardation factor, $R_{i}$

range in concentration between regenerated particle and adjacent node having

lower concentration

aquifer bulk density, $\rho_{b}$

range in concentration between regenerated particle and adjacent node having

higher concentration

storage coefficient (or specific yield)

rate of leakage through confining layer or streambed

change in total solute mass in storage (by summation)

initial mass of solute in storage

summation of concentrations of all particles in a cell

change in total solute mass in storage (from inflows-outflows)

total elapsed time (in seconds), $t$

cumulative elapsed time during particle moves (in seconds)

current time step, $\Delta t$

decay half-life, in seconds, $\mathrm{t}_{1 / 2}$

saturated thickness of aquifer, $b$

length of specific time step (in seconds)

elapsed time in days

elapsed time in years 
TIMV

TIMX

TINIT

TITLE

TMCN

TMOBS

TMRX

TMWL

TOL

TOTLQ

TRAN

UP

UPCOEF

UPTAKE

VMAX

VMAX

VMAY

VMGE

VMXDB

VMYBD

VPRM

VX

VXBDY

VY

VYBDY

WT

XDEL

XOLD

XPROF

XVEL

YDEL

YIELD

YIELDNUT

YOLD

YVEL

$\mathrm{Z}$

ZINHIB

ZINHIBFAC

ZINIT

ZPROF length of time increment for particle movement (in seconds)

time step multiplier for transient problems

size of initial time step for transient flow problems (in seconds)

problem description

computed concentrations at observation points

elapsed times for observation point records

transmissivity coefficients (harmonic means on cell boundaries; forward values are stored)

computed heads at observation points

convergence criteria

cumulative net leakage through confining layer or streambed

transverse dispersivity of porous medium

uptake of primary substrate or nutrient in a biodegradation process, $v^{n} ; v_{n u t}$

uptake coefficient of solute $i$ for biodegradation process $n, \beta_{i}^{n}$

uptake rate of substrate by biodegradation process $n, v^{n} ; v_{n u t}$

maximum value of VX (in subroutine VELO)

asymptotic maximum specific uptake rate of the substrate

maximum value of $\mathrm{VY}$

magnitude of velocity vector

maximum value of VXBDY

maximum value of VYBDY

initially used to read transmissivity (or hydraulic conductivity) values at nodes;

then after line B2270, VPRM equals leakance factor for confining layer or

streambed. If VPRM $\geq 0.09$, then the program assumes that the node is a constant-

head boundary and is flagged for subsequent special treatment in calculating

advective transport.

velocity in x-direction at a node, $V_{j}$

velocity in $\mathrm{x}$-direction on a boundary between nodes

velocity in y-direction at a node, $V_{j}$

velocity in y-direction on a boundary between nodes

initial water-table or potentiometric elevation, or constant head in stream or source

bed, $H_{s}$

grid spacing in $\mathrm{x}$-direction

$\mathrm{x}$-coordinate of particle at end of previous time increment

distance for water table profile

velocity of particle in $\mathrm{x}$-direction

grid spacing in $\mathrm{y}$-direction

cell-yield coefficient, $Y$

cell-yield coefficient of a nutrient, $Y_{n u t}$

$\mathrm{y}$-coordinate of particle at end of previous time increment

velocity of particle in $y$-direction

biomass concentration, $X_{k}^{n}$

biomass inhibition constant, $\mathrm{k}_{\text {bio }}$

biomass inhibition factor, $I_{b}$

initial biomass concentration, $X_{o}$

biomass concentration for water table profile 


\section{APPENDIX C: DATA INPUT FORMATS}

\begin{tabular}{|c|c|c|c|c|}
\hline Line & Column & Format & Variable & Definition \\
\hline 1 & $1-80$ & 10A8 & TITLE & Description of problem \\
\hline \multirow[t]{13}{*}{2} & & FREE & NTIM & $\begin{array}{l}\text { Maximum number of flow time steps in a pump- } \\
\text { ing period }\end{array}$ \\
\hline & & FREE & NPMP & $\begin{array}{l}\text { Number of pumping periods. Note that if } \\
\text { NPMP }>1 \text {, then data set } 22 \text { must be completed }\end{array}$ \\
\hline & & FREE & NX & $\begin{array}{l}\text { Number of nodes in } \mathrm{x} \text { direction, if } \mathrm{NX}<0 \text { then a } \\
\text { transport subgrid must be specified in a follow- } \\
\text { ing data set }\end{array}$ \\
\hline & & FREE & NY & Number of nodes in y direction \\
\hline & & FREE & NPMAX & Maximum number of particles \\
\hline & & FREE & NPNT & $\begin{array}{l}\text { Flow time-step interval for printing hydraulic } \\
\text { and chemical output data }\end{array}$ \\
\hline & & FREE & NITP & Number of iteration parameters \\
\hline & & FREE & NUMOBS & $\begin{array}{l}\text { Number of observation points to be specified in } \\
\text { data set } 1\end{array}$ \\
\hline & & FREE & ITMAX & Maximum allowable number of iterations \\
\hline & & FREE & NREC & $\begin{array}{l}\text { Number of pumping or injection wells to be } \\
\text { specified in data set } 2\end{array}$ \\
\hline & & FREE & NPTPND & $\begin{array}{l}\text { Initial number of particles per node (options }= \\
4,5,8,9,16)\end{array}$ \\
\hline & & FREE & NCODES & $\begin{array}{l}\text { Number of node identification codes to be speci- } \\
\text { fied in data set } 7\end{array}$ \\
\hline & & FREE & NPNTMV & $\begin{array}{l}\text { Particle movement interval (IMOV) for printing } \\
\text { chemical output data (Specify } 0 \text { to print only at } \\
\text { end of a flow time step) }\end{array}$ \\
\hline
\end{tabular}




\begin{tabular}{|c|c|c|c|c|}
\hline Line & Column & Format & Variable & Definition \\
\hline & & FREE & NPNTVL & $\begin{array}{l}\text { Option for printing computed velocities }(0=\text { do } \\
\text { not print; } 1=\text { print for first time step; } 2=\text { print for } \\
\text { all time steps) }\end{array}$ \\
\hline & & FREE & NPNTD & $\begin{array}{l}\text { Option for printing computed dispersion equa- } \\
\text { tion coefficients (option definition same as for } \\
\text { NPNTVL) }\end{array}$ \\
\hline & & FREE & NPDELC & $\begin{array}{l}\text { Option for printing computed changes in con- } \\
\text { centration ( } 0=\text { do not print; } 1=\text { print) }\end{array}$ \\
\hline & & FREE & NPNCHV & $\begin{array}{l}\text { Option to write velocity data to unit } 7 \text { (option } \\
\text { definition same as for NPNTVL) }\end{array}$ \\
\hline \multirow[t]{4}{*}{3} & & FREE & IBIO & $\begin{array}{l}\text { Biodegradation options, } 0=\text { no biodegradation; } \\
1=\text { multiple Monod; } 2=\text { minimum Monod }\end{array}$ \\
\hline & & FREE & NSOL & Total number of solute species \\
\hline & & FREE & NPOP & Total number of microbe populations \\
\hline & & FREE & NPSET & Total number of particle sets \\
\hline \multirow[t]{3}{*}{$\begin{array}{c}4 \text { to } \\
\text { npset }+3\end{array}$} & $1-5$ & I5 & IREACT(kp) & $\begin{array}{l}\text { Particle set } k p \text { reaction type: }-1=\text { decay only, } \\
0=\text { no reaction, } 1=\text { linear sorption and optional } \\
\text { decay }\end{array}$ \\
\hline & $6-10$ & $\mathrm{I} 5$ & NCONC(kp) & Number of solutes associated with particle set $k p$ \\
\hline & $11-15$ & I5 & $\mathrm{IMOB}(\mathrm{kp})$ & $\begin{array}{l}\text { Flag indicating mobility of particle set, } \\
0=\text { =mobile, } 1=\text { immobile }\end{array}$ \\
\hline \multirow[t]{4}{*}{ npset +4} & & FREE & MX & $\begin{array}{l}\text { Grid index for lower } x \text { limit of transport subgrid } \\
(\text { this parameter should be included only if } \\
N X<0)\end{array}$ \\
\hline & & FREE & MY & $\begin{array}{l}\text { Grid index for lower y limit of transport subgrid } \\
\text { (this parameter should be included only if } \\
\text { NY<0) }\end{array}$ \\
\hline & & FREE & MMX & $\begin{array}{l}\text { Grid index for upper } x \text { limit of transport subgrid } \\
(\text { this parameter should be included only if } \\
N X<0)\end{array}$ \\
\hline & & FREE & MMY & $\begin{array}{l}\text { Grid index for upper y limit of transport subgrid } \\
\text { (this parameter should be included only if } \\
\text { NY<0) }\end{array}$ \\
\hline
\end{tabular}




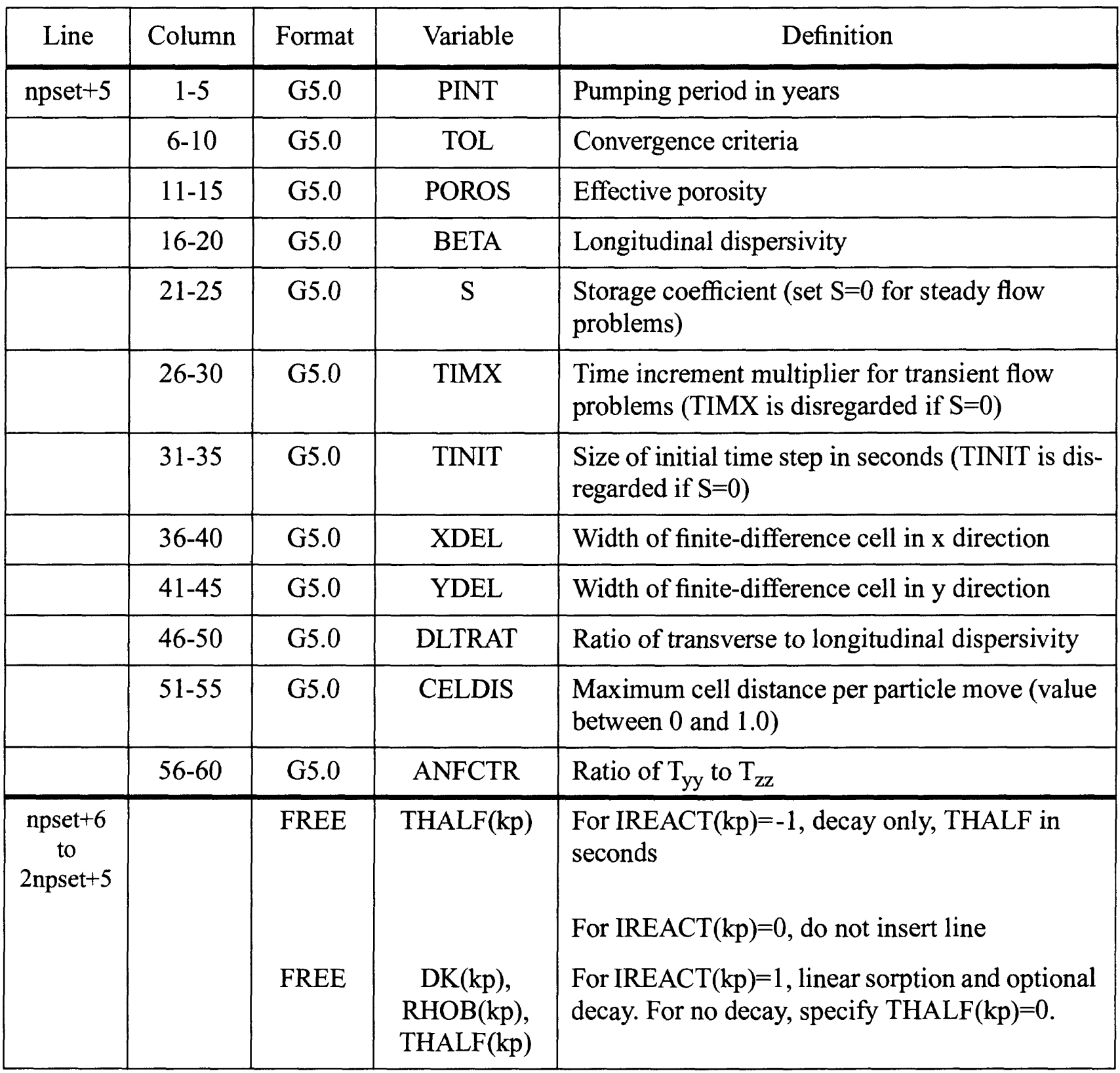




\begin{tabular}{|c|c|c|c|c|}
\hline $\begin{array}{c}\text { Data } \\
\text { set }\end{array}$ & $\begin{array}{l}\text { Number } \\
\text { of lines }\end{array}$ & Format & Variable & Definition \\
\hline 1 & NUMOBS & $2 \mathrm{I} 5$ & $\begin{array}{l}\text { IXOBS, } \\
\text { IYOBS }\end{array}$ & $\begin{array}{l}x \text { and } y \text { coordinates of observation points } \\
\text { (this data set is eliminated if NUMOBS }=0 \text { ) }\end{array}$ \\
\hline 2 & NREC & $\begin{array}{c}2 \mathrm{I} 5 \\
(10 \mathrm{G} 10.2)\end{array}$ & $\begin{array}{l}\text { IX,IY,FCTR, } \\
\text { CNREC(ks), } \\
\text { ks=1,NSOL }\end{array}$ & $\begin{array}{l}\mathrm{x} \text { and y coordinates of pumping }(+) \text { or injec- } \\
\text { tion }(-) \text { wells, pumping rate, and if an injec- } \\
\text { tion well, the concentration of each solute in } \\
\text { the injected water (this data set is eliminated } \\
\text { if } N R E C=0 \text { ) }\end{array}$ \\
\hline \multirow[t]{2}{*}{3} & 1 & $\mathrm{I} 1, \mathrm{G} 10.0$ & $\begin{array}{l}\text { INPUT, } \\
\text { FCTR }\end{array}$ & ${ }^{1}$ Parameter card for VPRM \\
\hline & NY & $8 \mathrm{E} 10.3$ & VPRM & $\begin{array}{l}\text { Transmissivity (or hydraulic conductivity in } \\
\text { a vertical cross-section) data, for an anisotro- } \\
\text { pic aquifer read in values of } T_{x x}\left(K_{x x}\right) \text { and } T_{y y} \\
\left(K_{y y}\right) \text { will be calculated using ANFCTR }\end{array}$ \\
\hline \multirow[t]{2}{*}{4} & 1 & $\mathrm{I} 1, \mathrm{G} 10.0$ & $\begin{array}{l}\text { INPUT, } \\
\text { FCTR }\end{array}$ & ${ }^{1}$ Parameter card for THCK \\
\hline & NY & $20 \mathrm{G} 3.0$ & THCK & $\begin{array}{l}\text { Saturated thickness (or unit width in a verti- } \\
\text { cal cross-section) of aquifer }\end{array}$ \\
\hline \multirow[t]{2}{*}{5} & 1 & $\mathrm{I} 1, \mathrm{G} 10.0$ & $\begin{array}{l}\text { INPUT, } \\
\text { FCTR }\end{array}$ & ${ }^{1}$ Parameter card for $\mathrm{RECH}$ \\
\hline & NY & $20 \mathrm{G} 4.1$ & $\mathrm{RECH}$ & Diffuse recharge $(-)$ or discharge $(+)$ \\
\hline \multirow[t]{2}{*}{6} & 1 & $\mathrm{I} 1, \mathrm{G} 10.0$ & $\begin{array}{l}\text { INPUT, } \\
\text { FCTR }\end{array}$ & ${ }^{1}$ Parameter card for NODEID \\
\hline & NY & 2011 & NODEID & $\begin{array}{l}\text { Node identification matrix (used to define } \\
\text { boundary conditions and stresses) }\end{array}$ \\
\hline 7 & NCODES & $\begin{array}{l}\mathrm{I} 2,3 \mathrm{~g} 10.2 \\
\mathrm{I} 2,9 \mathrm{~g} 10.2 / \\
(34 \mathrm{x} \\
9 \mathrm{~g} 10.2)\end{array}$ & $\begin{array}{l}\text { ICODE, FCTR1, } \\
\text { FCTR2(1), } \\
\text { FCTR3, } \\
\text { OVERRD, } \\
\text { fctr2(ks), } \\
\text { ks=2,nsol }\end{array}$ & $\begin{array}{l}\text { Instructions for using NODEID array. When } \\
\text { NODEID }=\text { ICODE, program sets leak- } \\
\text { ance }=\text { FCTR } 1, \text { CNRECH }(\mathrm{ks})=\text { FCTR } 2(\mathrm{ks}) \text {, } \\
\text { and if OVERRD } \neq 0, \mathrm{RECH}=\text { FCTR } 3 \text {. Set } \\
\text { OVERRD }=0 \text { to preserve values of RECH } \\
\text { specified in data set } 5 \text {. }\end{array}$ \\
\hline \multirow[t]{2}{*}{8} & 1 & $\mathrm{I} 1, \mathrm{G} 10.0$ & $\begin{array}{l}\text { INPUT, } \\
\text { FCTR }\end{array}$ & ${ }^{1}$ Parameter card for WT \\
\hline & NY & $\begin{array}{l}1 \mathrm{X} \\
10 \mathrm{~F} 12.0\end{array}$ & WT & $\begin{array}{l}\text { Initial water-table or potentiometric eleva- } \\
\text { tion, or constant head in stream or source bed }\end{array}$ \\
\hline
\end{tabular}




\begin{tabular}{|c|c|c|c|c|}
\hline $\begin{array}{c}\text { Data } \\
\text { set }\end{array}$ & $\begin{array}{l}\text { Number } \\
\text { of lines }\end{array}$ & Format & Variable & Definition \\
\hline & & & & Repeat data set 19 for each solute \\
\hline \multirow[t]{3}{*}{9} & 1 & $\mathrm{I} 1, \mathrm{G} 10.0$ & $\begin{array}{l}\text { INPUT, } \\
\text { FCTR }\end{array}$ & ${ }^{1}$ Parameter card for $\mathrm{CONC}(\mathrm{ks})$ \\
\hline & NY & $20 \mathrm{G} 4.0$ & $\mathrm{CONC}(\mathrm{ks})$ & Initial concentration of solute $k s$ in aquifer \\
\hline & & & & $\begin{array}{l}\text { The biodegradation parameters in data sets } \\
10 \text { through } 21 \text { should be included only if } \\
\text { IBIO }>0\end{array}$ \\
\hline \multirow[t]{2}{*}{10} & 1 & FREE & NPROC & $\begin{array}{l}\text { Number of simulated biodegradation pro- } \\
\text { cesses }\end{array}$ \\
\hline & & & & $\begin{array}{l}\text { Repeat data sets } 11-16 \text { for each biodegrada- } \\
\text { tion process iproc: }\end{array}$ \\
\hline \multirow[t]{7}{*}{11} & & FREE & NSPROC(iproc) & $\begin{array}{l}\text { Number of solutes undergoing microbial } \\
\text { uptake in process iproc }\end{array}$ \\
\hline & & FREE & VMAX(iproc) & $\begin{array}{l}\text { Asymptotic maximum specific uptake rate } \\
V_{\max } \text { of process iproc }\end{array}$ \\
\hline & & FREE & IZ(iproc) & $\begin{array}{l}\text { Index of microbe population performing pro- } \\
\text { cess iproc }\end{array}$ \\
\hline & & FREE & YIELD(iproc) & Yield of process iproc \\
\hline & & FREE & NCOMP(iproc) & $\begin{array}{l}\text { Number of solutes competitively inhibiting } \\
\text { process iproc }\end{array}$ \\
\hline & & FREE & NNC(iproc) & $\begin{array}{l}\text { Number of solutes noncompetitively inhibit- } \\
\text { ing process iproc }\end{array}$ \\
\hline & & FREE & NHAL(iproc) & $\begin{array}{l}\text { Number of solutes causing Haldane inhibi- } \\
\text { tion of process iproc }\end{array}$ \\
\hline & & & & $\begin{array}{l}\text { Repeat data set } 12 \text { for each solute undergoing } \\
\text { microbial uptake in process iproc } \\
\text { (is=1,nsproc). The first solute listed must be } \\
\text { the substrate used in process iproc: }\end{array}$ \\
\hline \multirow[t]{2}{*}{12} & & FREE & KSPROC(iproc,is) & Solute index \\
\hline & & FREE & HFK(iproc, is) & Half saturation constant for solute $k s p r o c$ \\
\hline & & & & $\begin{array}{l}\text { Repeat data set } 13 \text { for each solute competi- } \\
\text { tively inhibiting process iproc } \\
\text { (nc=1,ncomp(iproc)) }\end{array}$ \\
\hline
\end{tabular}




\begin{tabular}{|c|c|c|c|c|}
\hline $\begin{array}{c}\text { Data } \\
\text { set }\end{array}$ & $\begin{array}{l}\text { Number } \\
\text { of lines }\end{array}$ & Format & Variable & Definition \\
\hline \multirow[t]{2}{*}{13} & & FREE & $\begin{array}{l}\text { KSCOMP } \\
\text { (iproc,nc) }\end{array}$ & $\begin{array}{l}\text { index of solute competitively inhibiting pro- } \\
\text { cess irpoc }\end{array}$ \\
\hline & & FREE & $\begin{array}{l}\text { FACCOMP } \\
\text { (iproc,nc) }\end{array}$ & $\begin{array}{l}\text { competitive inhibition constant for solute } \\
\text { kscomp(iproc,nc) }\end{array}$ \\
\hline & & & & $\begin{array}{l}\text { Repeat data set } 14 \text { for each solute noncom- } \\
\text { petitively inhibiting process iproc } \\
(n c=1, n n c(\text { iproc)) }\end{array}$ \\
\hline \multirow[t]{2}{*}{14} & & FREE & KSNC(iproc,nc) & $\begin{array}{l}\text { index of solute noncompetitively inhibiting } \\
\text { process iproc }\end{array}$ \\
\hline & & FREE & $\begin{array}{l}\text { FACNC } \\
\text { (iproc,nc) }\end{array}$ & $\begin{array}{l}\text { noncompetitive inhibition constant for solute } \\
\text { KSNC(iproc,nc) }\end{array}$ \\
\hline & & & & $\begin{array}{l}\text { Repeat data set } 15 \text { for each solute causing } \\
\text { haldane inhibition of process iproc } \\
\text { (nc=1,NHAL(iproc)) }\end{array}$ \\
\hline \multirow[t]{2}{*}{15} & & FREE & $\begin{array}{l}\text { KSHAL } \\
\text { (iproc,nc) }\end{array}$ & $\begin{array}{l}\text { index of solute causing Haldane inhibition of } \\
\text { process irpoc }\end{array}$ \\
\hline & & FREE & $\begin{array}{l}\text { FACHAL } \\
\text { (iproc,nc) }\end{array}$ & $\begin{array}{l}\text { Haldane inhibition constant for solute } \\
\text { KSHAL(iproc,nc) }\end{array}$ \\
\hline 16 & & FREE & $\begin{array}{r}\text { UPCOEF } \\
\text { (iproc,ks), } \\
\mathrm{ks}=1, \mathrm{NSOL}\end{array}$ & $\begin{array}{l}\text { Uptake coefficient for each solute } k s:=0 \text { for } \\
\text { solutes not involved in process iproc } ;>0 \text { for } \\
\text { solutes consumed in process iproc } ;<0 \text { for } \\
\text { solutes produced in process iproc. }\end{array}$ \\
\hline \multirow[t]{2}{*}{17} & & FREE & NUMNUT & Number of cellular nutrients \\
\hline & & & & $\begin{array}{l}\text { Repeat data set } 18 \text { for each cellular nutrient } \\
\text { inn (inn }=1, N U M N U T \text { ) }\end{array}$ \\
\hline \multirow[t]{4}{*}{18} & & FREE & KSNUT(inn) & Nutrient solute index \\
\hline & & FREE & YIELDNUT(inn) & Nutrient yield \\
\hline & & FREE & HFKNUT(inn) & Nutrient half saturation constant \\
\hline & & FREE & RELCOEF & Nutrient release coefficient \\
\hline 19 & & FREE & $\begin{array}{l}\text { DEATH(ib), } \\
\mathrm{ib}=1, \mathrm{NPOP}\end{array}$ & Death rate of each microbe population $i b$ \\
\hline 20 & & FREE & NZINHIB & $\begin{array}{l}\text { Biomass inhibition flag: }=0 \text { no biomass inhi- } \\
\text { bition: }=1 \text { biomass inhibition. }\end{array}$ \\
\hline
\end{tabular}




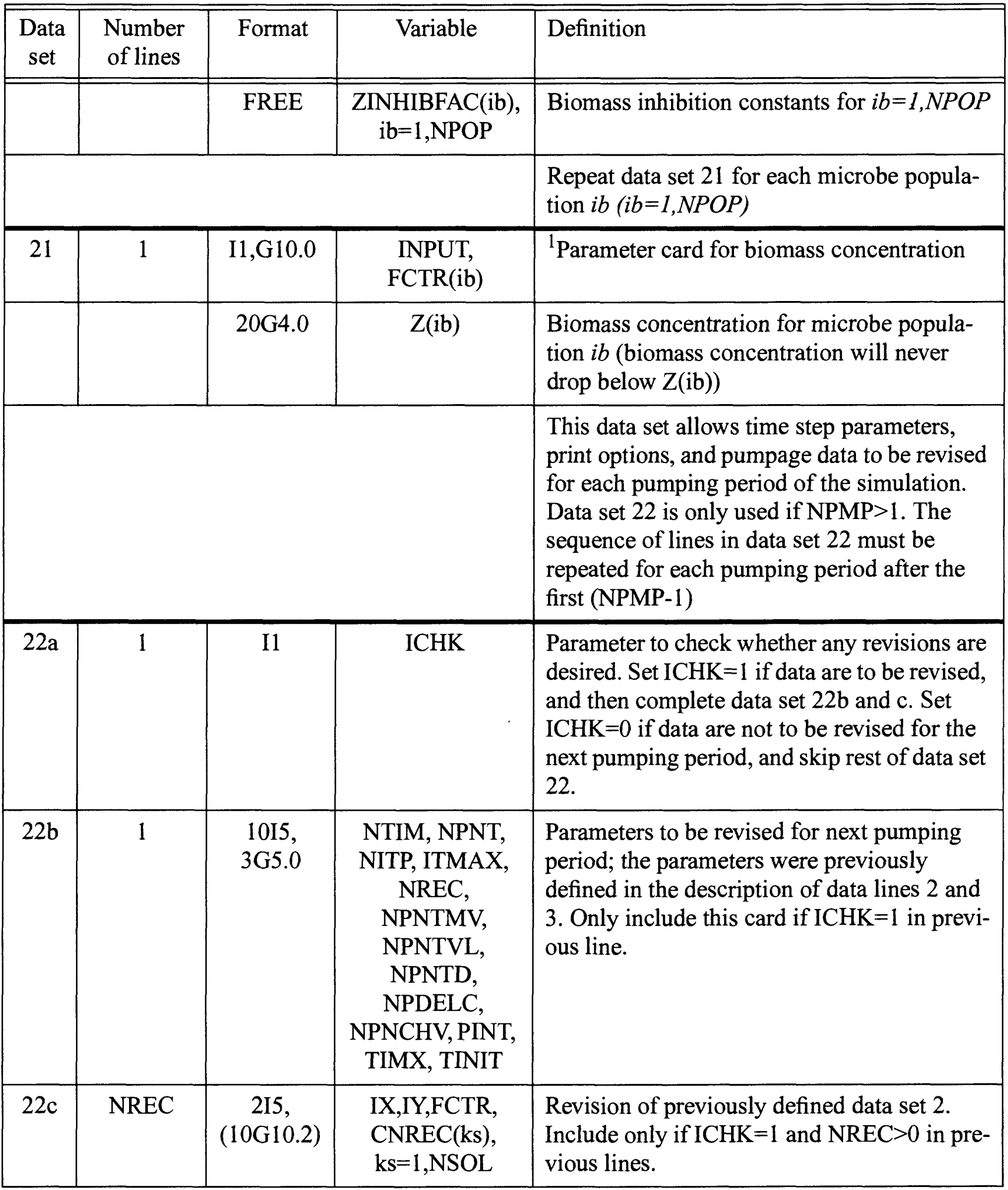

1. The parameter line must be the first line of the indicated data sets. If INPUT $=0$, the data set has a constant value, which is defined by FCTR and there is no need for further input. If INPUT=1, the data set varies in space, and the full data set must be specified as described in the subsequent input lines. In this case, FCTR is a multiplication factor for the values read in the data set. 


\begin{tabular}{|c|c|c|c|c|c|}
\hline 1 & 0.100 & 00.0 & 0.00 & 0.0 & 9.0 \\
\hline 0 & 1.0 & WT Init & tal head & & \\
\hline 0 & 0.0 & $\operatorname{CONC}(1)$ & Initial & concentration of & solute 1 \\
\hline 0 & 0.0 & $\operatorname{CONC}(2)$ & Initial & concentration of & solute 2 \\
\hline 0 & $\begin{array}{l}8.5 \\
2\end{array}$ & $\operatorname{CONC}(3)$ & Initial & $\begin{array}{l}\text { concentration of } \\
\text { [nproc] }\end{array}$ & solute 3 \\
\hline
\end{tabular}

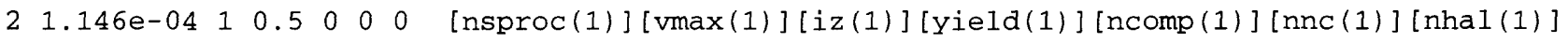
$\begin{array}{llll}1 & 17.4 & 3 & 0.1\end{array}$
$[\operatorname{ksproc}(1, i s)][\operatorname{hfk}(1, i s)]$

1. 0.2 .190 .0

[upcoef $(1, \mathrm{ks})]$

$29.606 e-0520.50000$ [nsproc(2)] $[\operatorname{vmax}(2)][i z(2)][y i e l d(2)][\operatorname{ncomp}(2)][\operatorname{nnc}(2)][\operatorname{nhal}(2)]$
$2 \quad 12.2 \quad 3 \quad 0.1$
$[\operatorname{ksproc}(2, i s)][\operatorname{hfk}(2, i s)]$

0. 1.2 .15

[ upcoef $(2, \mathrm{ks})]$

0

[numnut]

$1.157 e-06$

$1.157 e-06$

[death (ib)]

$\begin{array}{lllll}0 & 0.25 & 0.25 & 0.25 & {[\text { [nzinhib] [zinhibfac] }} \\ 0.8200 & & & & {[\mathrm{z} 1]} \\ 0.2100 & & & & {[\mathrm{z} 2]}\end{array}$




\section{APPENDIX E: SELECTED OUTPUT FOR TEST PROBLEM}

Selected sections of the output file BIOMOC.OUT for the test problem Aerobic Biodegradation and Transport of Toluene and Benzene (see Model Evaluation section) are given below. The input file for this problem is given in Appendix D.

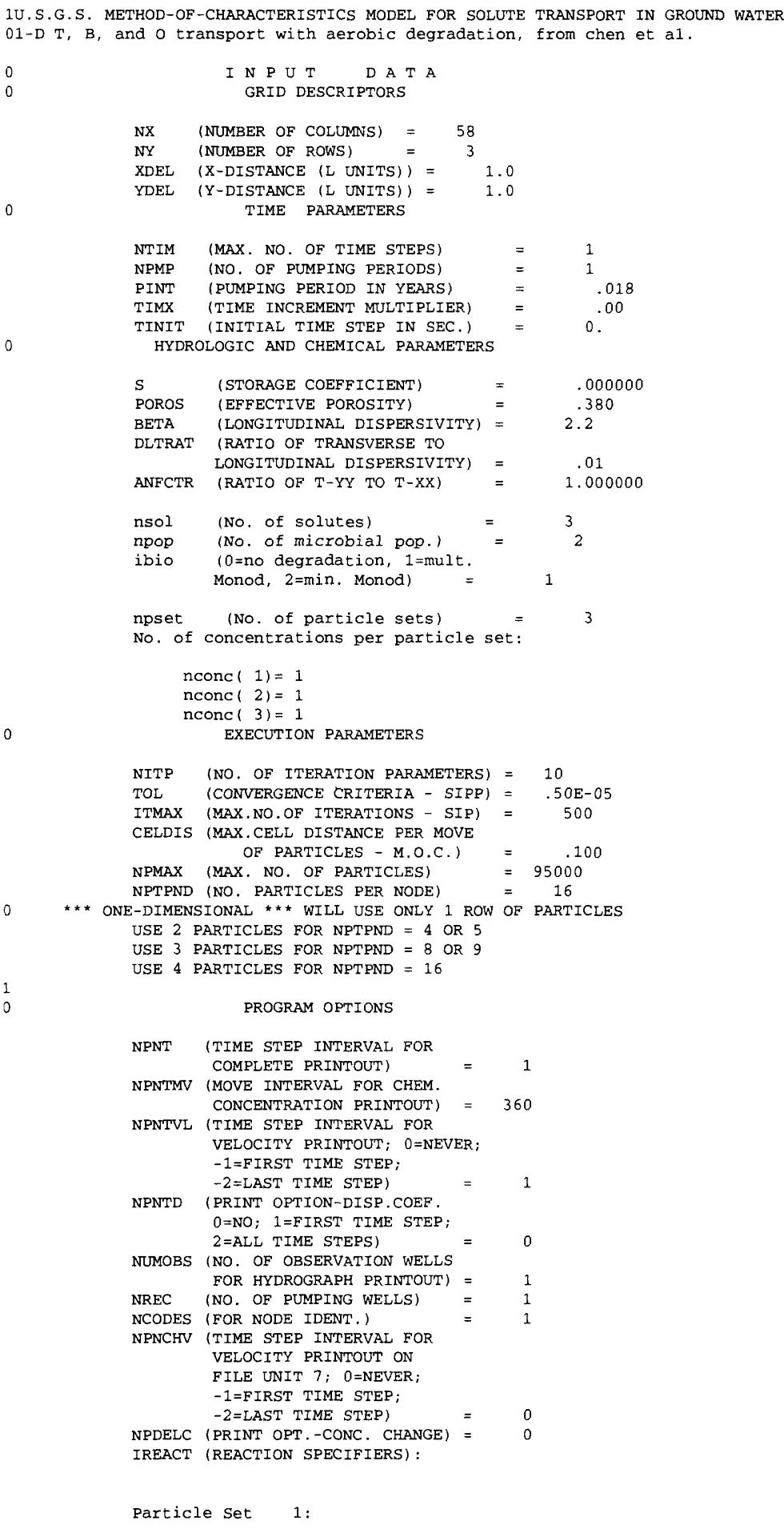


REACTION - LINEAR SORPTION

$\begin{array}{lll}\text { RHOB } & \text { (BULK DENSITY) } & =1.64000 E+00 \\ \text { DK } & \text { (DISTRIBUTION COEFFICIENT) } & =1.39000 E-01 \\ \text { RF } & \text { (RETARDATION FACTOR) } & =1.59989 E+00\end{array}$

Particle set 2 :

REACTION - LINEAR SORPTION

RHOB (BULK DENSITY) $=1.64000 \mathrm{E}+00$

DK (DISTRIBUTION COEFFICIENT) $=9.30000 \mathrm{E}-02$

RF (RETARDATION FACTOR) $=1.40137 E+00$

Particle set 3 :

REACTION - NONE

STEADY-STATE FLOW

TIME INTERVALS (IN SEC) FOR SOLUTE-TRANSPORT SIMULATION $.57119 E+06$

LOCATION OF OBSERVATION WELLS

No. $\mathrm{X} \quad \mathrm{Y}$

$1 \quad 57 \quad 2$

LOCATION OF PUMPING WELLS

$X \quad Y$ RATE (IN CFS) SOLUTE CONC. $(1,2, \ldots$, NSOL)

$2 \quad 2 \quad-.145 E-03 \quad .200 E+02 \quad .200 E+02 \quad .133 E+03$

$0 \quad$ AREA OF ONE CELL $=1.000$

$X-Y$ SPACING:

1.0000

1.0000

1TRANSMISSIVITY MAP $\left(L^{\star \star} 2 / \mathrm{SEC}\right)$

$\begin{array}{rrrrrrrrrr}.00 E+00 & .00 E+00 & .00 E+00 & .00 E+00 & .00 E+00 & .00 E+00 & .00 E+00 & .00 E+00 & .00 E+00 & .00 E+00 \\ .00 E+00 & .00 E+00 & .00 E+00 & .00 E+00 & .00 E+00 & .00 E+00 & .00 E+00 & .00 E+00 & .00 E+00 & .00 E+00 \\ .00 E+00 & .00 E+00 & .00 E+00 & .00 E+00 & .00 E+00 & .00 E+00 & .00 E+00 & .00 E+00 & .00 E+00 & .00 E+00 \\ .00 E+00 & .00 E+00 & .00 E+00 & .00 E+00 & .00 E+00 & .00 E+00 & .00 E+00 & .00 E+00 & .00 E+00 & .00 E+00 \\ .00 E+00 & .00 E+00 & .00 E+00 & .00 E+00 & .00 E+00 & .00 E+00 & .00 E+00 & .00 E+00 & .00 E+00 & .00 E+00 \\ .00 E+00 & .00 E+00 & .00 E+00 & .00 E+00 & .00 E+00 & .00 E+00 & .00 E+00 & .00 E+00 & & \\ .00 E+00 & 1.00 E-02 & 1.00 E-02 & 1.00 E-02 & 1.00 E-02 & 1.00 E-02 & 1.00 E-02 & 1.00 E-02 & 1.00 E-02 & 1.00 E-02 \\ 1.00 E-02 & 1.00 E-02 & 1.00 E-02 & 1.00 E-02 & 1.00 E-02 & 1.00 E-02 & 1.00 E-02 & 1.00 E-02 & 1.00 E-02 & 1.00 E-02\end{array}$

$\begin{array}{llllllllll}1.00 \mathrm{E}-02 & 1.00 \mathrm{E}-02 & 1.00 \mathrm{E}-02 & 1.00 \mathrm{E}-02 & 1.00 \mathrm{E}-02 & 1.00 \mathrm{E}-02 & 1.00 \mathrm{E}-02 & 1.00 \mathrm{E}-02 & 1.00 \mathrm{E}-02 & 1.00 \mathrm{E}-02\end{array}$

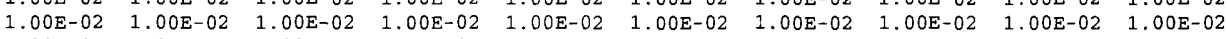

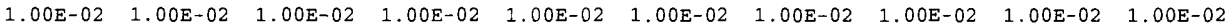

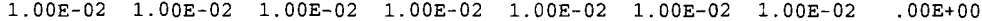

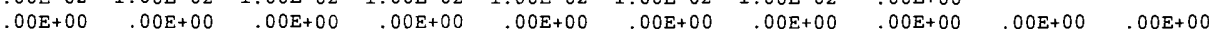

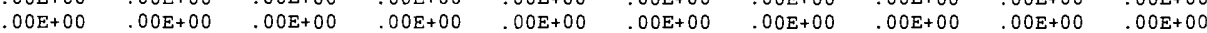

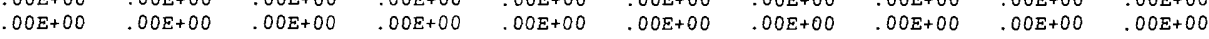

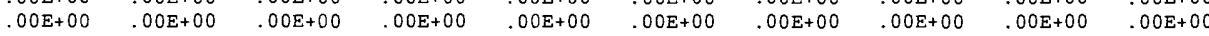

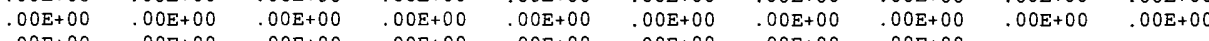

1 AOUTFER THICKNESS (L)

$\begin{array}{rrrrrrrrrr}.00 E+00 & .00 E+00 & .00 E+00 & .00 E+00 & .00 E+00 & .00 E+00 & .00 E+00 & .00 E+00 & .00 E+00 & .00 E+00 \\ .00 E+00 & .00 E+00 & .00 E+00 & .00 E+00 & .00 E+00 & .00 E+00 & .00 E+00 & .00 E+00 & .00 E+00 & .00 E+00 \\ .00 E+00 & .00 E+00 & .00 E+00 & .00 E+00 & .00 E+00 & .00 E+00 & .00 E+00 & .00 E+00 & .00 E+00 & .00 E+00 \\ .00 E+00 & .00 E+00 & .00 E+00 & .00 E+00 & .00 E+00 & .00 E+00 & .00 E+00 & .00 E+00 & .00 E+00 & .00 E+00 \\ .00 E+00 & .00 E+00 & .00 E+00 & .00 E+00 & .00 E+00 & .00 E+00 & .00 E+00 & .00 E+00 & .00 E+00 & .00 E+00 \\ .00 E+00 & .00 E+00 & .00 E+00 & .00 E+00 & .00 E+00 & .00 E+00 & .00 E+00 & .00 E+00 & & \\ .00 E+00 & 1.00 E+00 & 1.00 E+00 & 1.00 E+00 & 1.00 E+00 & 1.00 E+00 & 1.00 E+00 & 1.00 E+00 & 1.00 E+00 & 1.00 E+00 \\ 1.00 E+00 & 1.00 E+00 & 1.00 E+00 & 1.00 E+00 & 1.00 E+00 & 1.00 E+00 & 1.00 E+00 & 1.00 E+00 & 1.00 E+00 & 1.00 E+00\end{array}$

$\begin{array}{llllllllll}1.00 E+00 & 1.00 E+00 & 1.00 E+00 & 1.00 E+00 & 1.00 E+00 & 1.00 E+00 & 1.00 E+00 & 1.00 E+00 & 1.00 E+00 & 1.00 E+00\end{array}$

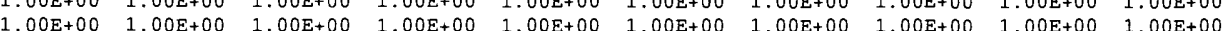

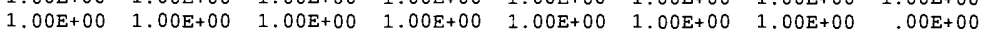

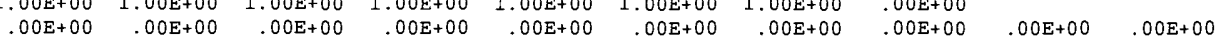

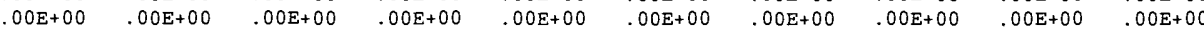

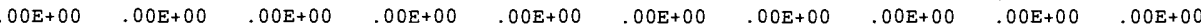

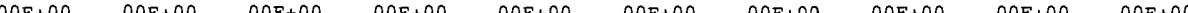

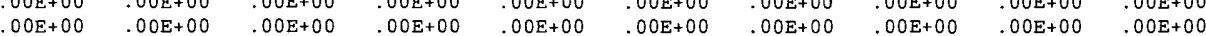

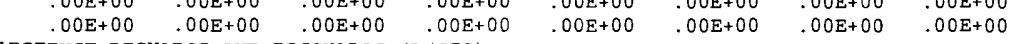

$00 E+00$

$\begin{array}{llllllllll}.00 E+00 & .00 E+00 & .00 E+00 & .00 E+00 & .00 E+00 & .00 E+00 & .00 E+00 & .00 E+00 & .00 E+00 & .00 E+00 \\ .00 E+00 & .00 E+00 & .00 E+00 & .00 E+00 & .00 E+00 & .00 E+00 & .00 E+00 & .00 E+00 & .00 E+00 & .00 E+00 \\ .00 E+00 & .00 E+00 & .00 E+00 & .00 E+00 & .00 E+00 & .00 E+00 & .00 E+00 & .00 E+00 & .00 E+00 & .00 E+00 \\ .00 E+00 & .00 E+00 & .00 E+00 & .00 E+00 & .00 E+00 & .00 E+00 & .00 E+00 & .00 E+00 & .00 E+00 & .00 E+00 \\ .00 E+00 & .00 E+00 & .00 E+00 & .00 E+00 & .00 E+00 & .00 E+00 & .00 E+00 & .00 E+00 & .00 E+00 & .00 E+00 \\ .00 E+00 & .00 E+00 & .00 E+00 & .00 E+00 & .00 E+00 & .00 E+00 & .00 E+00 & .00 E+00 & & \\ .00 E+00 & .00 E+00 & .00 E+00 & .00 E+00 & .00 E+00 & .00 E+00 & .00 E+00 & .00 E+00 & .00 E+00 & .00 E+00\end{array}$




\begin{tabular}{|c|c|c|c|c|c|c|c|c|c|}
\hline $.00 \mathrm{E}+00$ & $.00 E+00$ & $.00 E+00$ & $.00 E+00$ & $.00 E+00$ & $.00 E+00$ & $.00 E+00$ & $.00 \mathrm{E}+00$ & $.00 E+00$ & $.00 E+00$ \\
\hline $.00 \mathrm{E}+00$ & $.00 E+00$ & $.00 \mathrm{E}+00$ & $.00 E+00$ & $.00 E+00$ & $.00 E+00$ & $.00 \mathrm{E}+00$ & $.00 E+00$ & $.00 E+00$ & $.00 E+00$ \\
\hline $.00 \mathrm{E}+00$ & $.00 E+00$ & $.00 E+00$ & $.00 \mathrm{E}+00$ & $.00 \mathrm{E}+00$ & $.00 E+00$ & $.00 E+00$ & $.00 \mathrm{E}+00$ & $.00 E+00$ & $.00 \mathrm{E}+00$ \\
\hline $.00 \mathrm{E}+00$ & $.00 \mathrm{E}+00$ & $.00 E+00$ & $.00 \mathrm{E}+00$ & $.00 \mathrm{E}+00$ & $.00 E+00$ & $.00 \mathrm{E}+00$ & $.00 \mathrm{E}+00$ & $.00 \mathrm{E}+00$ & $.00 \mathrm{E}+00$ \\
\hline $.00 \mathrm{E}+00$ & $.00 E+00$ & $.00 \mathrm{E}+00$ & $.00 E+00$ & $.00 \mathrm{E}+00$ & $.00 E+00$ & $.00 E+00$ & $.00 \mathrm{E}+00$ & & \\
\hline $.00 \mathrm{E}+00$ & $.00 E+00$ & $.00 E+00$ & $.00 E+00$ & $.00 \mathrm{E}+00$ & $.00 E+00$ & $.00 E+00$ & $.00 E+00$ & $.00 E+00$ & $.00 \mathrm{E}+00$ \\
\hline $.00 \mathrm{E}+00$ & $.00 \mathrm{E}+00$ & $.00 E+00$ & $.00 E+00$ & $.00 E+00$ & $.00 E+00$ & $.00 E+00$ & $.00 E+00$ & $.00 E+00$ & $.00 \mathrm{E}+00$ \\
\hline $.00 E+00$ & $.00 \mathrm{E}+00$ & $.00 E+00$ & $.00 E+00$ & $.00 E+00$ & $.00 E+00$ & $.00 E+00$ & $.00 E+00$ & $.00 E+00$ & $.00 E+00$ \\
\hline $.00 \mathrm{E}+00$ & $.00 E+00$ & $.00 E+00$ & $.00 E+00$ & $.00 \mathrm{E}+00$ & $.00 E+00$ & $.00 E+00$ & $.00 E+00$ & $.00 E+00$ & $.00 E+00$ \\
\hline $.00 E+00$ & $.00 \mathrm{E}+00$ & $.00 \mathrm{E}+00$ & $.00 E+00$ & $.00 \mathrm{E}+00$ & $.00 E+00$ & $.00 \mathrm{E}+00$ & $.00 E+00$ & $.00 E+00$ & $.00 E+00$ \\
\hline $.00 \mathrm{E}+00$ & $.00 E+00$ & $.00 \mathrm{E}+00$ & $.00 E+00$ & $.00 \mathrm{E}+00$ & $.00 E+00$ & $.00 E+00$ & $.00 E+00$ & & \\
\hline \multicolumn{10}{|c|}{ 1HYDRAULIC CONDUCTIVITY MAP (L/SEC) } \\
\hline $.00 \mathrm{E}+00$ & $.00 \mathrm{E}+00$ & $.00 \mathrm{E}+00$ & $.00 E+00$ & $.00 E+00$ & $.00 E+00$ & $.00 \mathrm{E}+00$ & $.00 E+00$ & $.00 E+00$ & $.00 \mathrm{E}+00$ \\
\hline $.00 \mathrm{E}+00$ & $.00 E+00$ & $.00 E+00$ & $.00 E+00$ & $.00 E+00$ & $.00 E+00$ & $.00 E+00$ & $.00 E+00$ & $.00 E+00$ & $.00 \mathrm{E}+00$ \\
\hline $.00 E+00$ & $.00 E+00$ & $.00 E+00$ & $.00 E+00$ & $.00 E+00$ & $.00 E+00$ & $.00 E+00$ & $.00 E+00$ & $.00 E+00$ & $.00 E+00$ \\
\hline $.00 E+00$ & $.00 \mathrm{E}+00$ & $.00 \mathrm{E}+00$ & $.00 E+00$ & $.00 \mathrm{E}+00$ & $.00 E+00$ & $.00 E+00$ & $.00 \mathrm{E}+00$ & $.00 \mathrm{E}+00$ & $.00 \mathrm{E}+00$ \\
\hline $.00 E+00$ & $.00 \mathrm{E}+00$ & $.00 \mathrm{E}+00$ & $.00 E+00$ & $.00 E+00$ & $.00 \mathrm{E}+00$ & $.00 \mathrm{E}+00$ & $.00 \mathrm{E}+00$ & $.00 E+00$ & $.00 \mathrm{E}+00$ \\
\hline $.00 \mathrm{E}+00$ & $.00 \mathrm{E}+00$ & $.00 E+00$ & $.00 E+00$ & $.00 \mathrm{E}+00$ & $.00 E+00$ & $.00 E+00$ & $.00 E+00$ & & \\
\hline $.00 E+00$ & $1.00 \mathrm{E}-02$ & $1.00 \mathrm{E}-02$ & $1.00 \mathrm{E}-02$ & $1.00 \mathrm{E}-02$ & $1.00 \mathrm{E}-02$ & $1.00 \mathrm{E}-02$ & $1.00 \mathrm{E}-02$ & $1.00 \mathrm{E}-02$ & $1.00 \mathrm{E}-02$ \\
\hline $1.00 \mathrm{E}-02$ & $1.00 \mathrm{E}-02$ & $1.00 \mathrm{E}-02$ & $1.00 \mathrm{E}-02$ & $1.00 \mathrm{E}-02$ & $1.00 \mathrm{E}-02$ & $1.00 \mathrm{E}-02$ & $1.00 \mathrm{E}-02$ & $1.00 \mathrm{E}-02$ & $1.00 \mathrm{E}-02$ \\
\hline $1.00 \mathrm{E}-02$ & $1.00 \mathrm{E}-02$ & $1.00 \mathrm{E}-02$ & $1.00 \mathrm{E}-02$ & $1.00 \mathrm{E}-02$ & $1.00 \mathrm{E}-02$ & $1.00 \mathrm{E}-02$ & $1.00 \mathrm{E}-02$ & $1.00 \mathrm{E}-02$ & $1.00 \mathrm{E}-02$ \\
\hline $1.00 \mathrm{E}-02$ & $1.00 \mathrm{E}-02$ & $1.00 \mathrm{E}-02$ & $1.00 \mathrm{E}-02$ & $1.00 \mathrm{E}-02$ & $1.00 \mathrm{E}-02$ & $1.00 \mathrm{E}-02$ & $1.00 \mathrm{E}-02$ & $1.00 \mathrm{E}-02$ & $1.00 \mathrm{E}-02$ \\
\hline $1.00 \mathrm{E}-02$ & $1.00 \mathrm{E}-02$ & $1.00 \mathrm{E}-02$ & $1.00 \mathrm{E}-02$ & $1.00 \mathrm{E}-02$ & $1.00 \mathrm{E}-02$ & $1.00 \mathrm{E}-02$ & $1.00 \mathrm{E}-02$ & $1.00 \mathrm{E}-02$ & $1.00 \mathrm{E}-02$ \\
\hline $1.00 \mathrm{E}-02$ & $1.00 \mathrm{E}-02$ & $1.00 \mathrm{E}-02$ & $1.00 \mathrm{E}-02$ & $1.00 \mathrm{E}-02$ & $1.00 \mathrm{E}-02$ & $1.00 \mathrm{E}-02$ & $.00 E+00$ & & \\
\hline $.00 \mathrm{E}+00$ & $.00 \mathrm{E}+00$ & $.00 \mathrm{E}+00$ & $.00 \mathrm{E}+00$ & $.00 \mathrm{E}+00$ & $.00 \mathrm{E}+00$ & $.00 \mathrm{E}+00$ & $.00 E+00$ & $.00 \mathrm{E}+00$ & $.00 E+00$ \\
\hline $.00 E+00$ & $.00 E+00$ & $.00 \mathrm{E}+00$ & $.00 \mathrm{E}+00$ & $.00 \mathrm{E}+00$ & $.00 E+00$ & $.00 E+00$ & $.00 E+00$ & $.00 E+00$ & $.00 E+00$ \\
\hline $.00 \mathrm{E}+00$ & $.00 E+00$ & $.00 \mathrm{E}+00$ & $.00 \mathrm{E}+00$ & $.00 E+00$ & $.00 E+00$ & $.00 E+00$ & $.00 E+00$ & $.00 E+00$ & $.00 E+00$ \\
\hline $.00 E+00$ & $.00 E+00$ & $.00 \mathrm{E}+00$ & $.00 E+00$ & $.00 E+00$ & $.00 E+00$ & $.00 E+00$ & $.00 E+00$ & $.00 E+00$ & $.00 E+00$ \\
\hline $.00 E+00$ & $.00 E+00$ & $.00 \mathrm{E}+00$ & $.00 \mathrm{E}+00$ & $.00 \mathrm{E}+00$ & $.00 E+00$ & $.00 E+00$ & $.00 E+00$ & $.00 \mathrm{E}+00$ & $.00 E+00$ \\
\hline $.00 E+00$ & $.00 E+00$ & $.00 \mathrm{E}+00$ & $.00 E+00$ & $.00 \mathrm{E}+00$ & $.00 E+00$ & $.00 E+00$ & $.00 E+00$ & & \\
\hline
\end{tabular}

AREA OF AQUIFER IN MODEL $=56.000 \quad \mathrm{~L}^{\star * 2}$

NZCRIT (MAX. NO, OF CELLS THAT CAN BE VOID OF

PARTICLES; IF EXCEEDED, PARTICLES ARE REGENERATED) = 1

1NODE IDENTIFICATION MAP

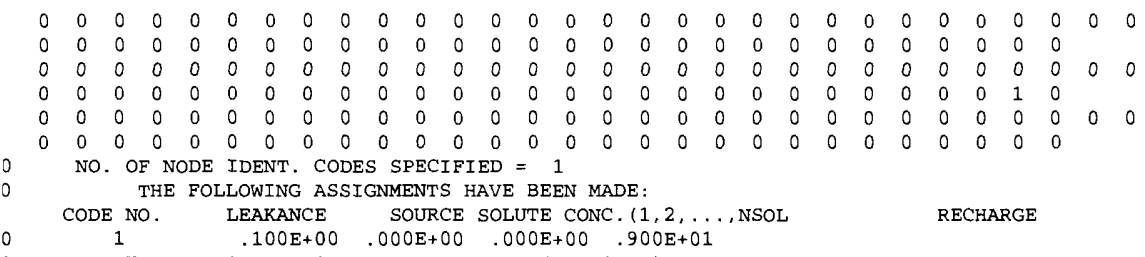

1VERTICAL HYDRAULIC CONDUCTIVITY/THICKNESS (L/(L*SEC))

$\begin{array}{llllllllll}.00 \mathrm{E}+00 & .00 \mathrm{E}+00 & .00 \mathrm{E}+00 & .00 \mathrm{E}+00 & .00 \mathrm{E}+00 & .00 \mathrm{E}+00 & .00 \mathrm{E}+00 & .00 \mathrm{E}+00 & .00 \mathrm{E}+00 & .00 \mathrm{E}+00 \\ .00 \mathrm{E}+00 & .00 \mathrm{E}+00 & .00 \mathrm{E}+00 & .00 \mathrm{E}+00 & .00 \mathrm{E}+00 & .00 \mathrm{E}+00 & .00 \mathrm{E}+00 & .00 \mathrm{E}+00 & .00 \mathrm{E}+00 & .00 \mathrm{E}+00 \\ .00 \mathrm{E}+00 & .00 \mathrm{E}+00 & .00 \mathrm{E}+00 & .00 \mathrm{E}+00 & .00 \mathrm{E}+00 & .00 \mathrm{E}+00 & .00 \mathrm{E}+00 & .00 \mathrm{E}+00 & .00 \mathrm{E}+00 & .00 \mathrm{E}+00 \\ .00 \mathrm{E}+00 & .00 \mathrm{E}+00 & .00 \mathrm{E}+00 & .00 \mathrm{E}+00 & .00 \mathrm{E}+00 & .00 \mathrm{E}+00 & .00 \mathrm{E}+00 & .00 \mathrm{E}+00 & .00 \mathrm{E}+00 & .00 \mathrm{E}+00 \\ .00 \mathrm{E}+00 & .00 \mathrm{E}+00 & .00 \mathrm{E}+00 & .00 \mathrm{E}+00 & .00 \mathrm{E}+00 & .00 \mathrm{E}+00 & .00 \mathrm{E}+00 & .00 \mathrm{E}+00 & .00 \mathrm{E}+00 & .00 \mathrm{E}+00 \\ .00 \mathrm{E}+00 & .00 \mathrm{E}+00 & .00 \mathrm{E}+00 & .00 \mathrm{E}+00 & .00 \mathrm{E}+00 & .00 \mathrm{E}+00 & .00 \mathrm{E}+00 & .00 \mathrm{E}+00 & & \\ .00 \mathrm{E}+00 & .00 \mathrm{E}+00 & .00 \mathrm{E}+00 & .00 \mathrm{E}+00 & .00 \mathrm{E}+00 & .00 \mathrm{E}+00 & .00 \mathrm{E}+00 & .00 \mathrm{E}+00 & .00 \mathrm{E}+00 & .00 \mathrm{E}+00 \\ .00 \mathrm{E}+00 & .00 \mathrm{E}+00 & .00 \mathrm{E}+00 & .00 \mathrm{E}+00 & .00 \mathrm{E}+00 & .00 \mathrm{E}+00 & .00 \mathrm{E}+00 & .00 \mathrm{E}+00 & .00 \mathrm{E}+00 & .00 \mathrm{E}+00 \\ .00 \mathrm{E}+00 & .00 \mathrm{E}+00 & .00 \mathrm{E}+00 & .00 \mathrm{E}+00 & .00 \mathrm{E}+00 & .00 \mathrm{E}+00 & .00 \mathrm{E}+00 & .00 \mathrm{E}+00 & .00 \mathrm{E}+00 & .00 \mathrm{E}+00 \\ .00 \mathrm{E}+00 & .00 \mathrm{E}+00 & .00 \mathrm{E}+00 & .00 \mathrm{E}+00 & .00 \mathrm{E}+00 & .00 \mathrm{E}+00 & .00 \mathrm{E}+00 & .00 \mathrm{E}+00 & .00 \mathrm{E}+00 & .00 \mathrm{E}+00 \\ .00 \mathrm{E}+00 & .00 \mathrm{E}+00 & .00 \mathrm{E}+00 & .00 \mathrm{E}+00 & .00 \mathrm{E}+00 & .00 \mathrm{E}+00 & .00 \mathrm{E}+00 & .00 \mathrm{E}+00 & .00 \mathrm{E}+00 & .00 \mathrm{E}+00 \\ .00 \mathrm{E}+00 & .00 \mathrm{E}+00 & .00 \mathrm{E}+00 & .00 \mathrm{E}+00 & .00 \mathrm{E}+00 & .00 \mathrm{E}+00 & 1.00 \mathrm{E}-01 & .00 \mathrm{E}+00 & & \\ .00 \mathrm{E}+00 & .00 \mathrm{E}+00 & .00 \mathrm{E}+00 & .00 \mathrm{E}+00 & .00 \mathrm{E}+00 & .00 \mathrm{E}+00 & .00 \mathrm{E}+00 & .00 \mathrm{E}+00 & .00 \mathrm{E}+00 & .00 \mathrm{E}+00 \\ .00 \mathrm{E}+00 & .00 \mathrm{E}+00 & .00 \mathrm{E}+00 & .00 \mathrm{E}+00 & .00 \mathrm{E}+00 & .00 \mathrm{E}+00 & .00 \mathrm{E}+00 & .00 \mathrm{E}+00 & .00 \mathrm{E}+00 & .00 \mathrm{E}+00 \\ .00 \mathrm{E}+00 & .00 \mathrm{E}+00 & .00 \mathrm{E}+00 & .00 \mathrm{E}+00 & .00 \mathrm{E}+00 & .00 \mathrm{E}+00 & .00 \mathrm{E}+00 & .00 \mathrm{E}+00 & .00 \mathrm{E}+00 & .00 \mathrm{E}+00 \\ .00 \mathrm{E}+00 & .00 \mathrm{E}+00 & .00 \mathrm{E}+00 & .00 \mathrm{E}+00 & .00 \mathrm{E}+00 & .00 \mathrm{E}+00 & .00 \mathrm{E}+00 & .00 \mathrm{E}+00 & .00 \mathrm{E}+00 & .00 \mathrm{E}+00 \\ .00 \mathrm{E}+00 & .00 \mathrm{E}+00 & .00 \mathrm{E}+00 & .00 \mathrm{E}+00 & .00 \mathrm{E}+00 & .00 \mathrm{E}+00 & .00 \mathrm{E}+00 & .00 \mathrm{E}+00 & .00 \mathrm{E}+00 & .00 \mathrm{E}+00 \\ .00 \mathrm{E}+00 & .00 \mathrm{E}+00 & .00 \mathrm{E}+00 & .00 \mathrm{E}+00 & .00 \mathrm{E}+00 & .00 \mathrm{E}+00 & .00 \mathrm{E}+00 & .00 \mathrm{E}+00 & & \end{array}$

1WATER TABLE

$\begin{array}{llllllllllllllllllll}0 . & 0 . & 0 . & 0 . & 0 . & 0 . & 0 . & 0 . & 0 . & 0 . & 0 . & 0 . & 0 . & 0 . & 0 . & 0 . & 0 . & 0 . & 0 . & 0 . \\ 0 . & 0 . & 0 . & 0 . & 0 . & 0 . & 0 . & 0 . & 0 . & 0 . & 0 . & 0 . & 0 . & 0 . & 0 . & 0 . & 0 . & 0 . & 0 . & 0 . \\ 0 . & 0 . & 0 . & 0 . & 0 . & 0 . & 0 . & 0 . & 0 . & 0 . & 0 . & 0 . & 0 . & 0 . & 0 . & 0 . & 0 . & 0 . & & 1 . \\ 0 . & 1 . & 1 . & 1 . & 1 . & 1 . & 1 . & 1 . & 1 . & 1 . & 1 . & 1 . & 1 . & 1 . & 1 . & 1 . & 1 . & 1 . & 1 . & 1 . \\ 1 . & 1 . & 1 . & 1 . & 1 . & 1 . & 1 . & 1 . & 1 . & 1 . & 1 . & 1 . & 1 . & 1 . & 1 . & 1 . & 1 . & 1 . & 1 . & 1 . \\ 1 . & 1 . & 1 . & 1 . & 1 . & 1 . & 1 . & 1 . & 1 . & 1 . & 1 . & 1 . & 1 . & 1 . & 1 . & 1 . & 1 . & 0 . & & \\ 0 . & 0 . & 0 . & 0 . & 0 . & 0 . & 0 . & 0 . & 0 . & 0 . & 0 . & 0 . & 0 . & 0 . & 0 . & 0 . & 0 . & 0 . & 0 . & 0 . \\ 0 . & 0 . & 0 . & 0 . & 0 . & 0 . & 0 . & 0 . & 0 . & 0 . & 0 . & 0 . & 0 . & 0 . & 0 . & 0 . & 0 . & 0 . & 0 . & 0 . \\ 0 . & 0 . & 0 . & 0 . & 0 . & 0 . & 0 . & 0 . & 0 . & 0 . & 0 . & 0 . & 0 . & 0 . & 0 . & 0 . & 0 . & 0 . & & \end{array}$

1 HEAD DISTRIBUTION - ROW

NUMBER OF TIME STEPS $=$

$\begin{array}{ll}\text { TIME (SECONDS) } & =.00000 \mathrm{E}+00 \\ \text { TIME (DAYS) } & =.00000 \mathrm{E}+00\end{array}$

$\begin{array}{ll}\text { TIME (DAYS) } & =.00000 \mathrm{E}+00 \\ \text { TIME (YEARS) } & =.00000 \mathrm{E}+00\end{array}$

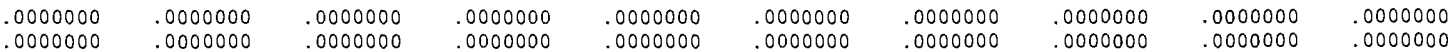




\begin{tabular}{|c|c|c|c|c|c|c|c|c|c|}
\hline .0000000 & .0000000 & .0000000 & .0000000 & .0000000 & .0000000 & .0000000 & .0000000 & .0000000 & .0000000 \\
\hline .0000000 & .0000000 & .0000000 & .0000000 & .0000000 & .0000000 & .0000000 & .0000000 & .0000000 & .0000000 \\
\hline .0000000 & .0000000 & .0000000 & .0000000 & .0000000 & .0000000 & .0000000 & .0000000 & .0000000 & .0000000 \\
\hline .0000000 & .0000000 & .0000000 & .0000000 & .0000000 & .0000000 & .0000000 & .0000000 & & \\
\hline .0000000 & 1.0000000 & 1.0000000 & 1.0000000 & 1.0000000 & 1.0000000 & 1.0000000 & 1.0000000 & 1.0000000 & 1.0000000 \\
\hline 1.0000000 & 1.0000000 & 1.0000000 & 1.0000000 & 1.0000000 & 1.0000000 & 1.0000000 & 1.0000000 & 1.0000000 & 1.0000000 \\
\hline 1.0000000 & 1.0000000 & 1.0000000 & 1.0000000 & 1.0000000 & 1.0000000 & 1.0000000 & 1.0000000 & 1.0000000 & 1.0000000 \\
\hline 1.0000000 & 1.0000000 & 1.0000000 & 1.0000000 & 1.0000000 & 1.0000000 & 1.0000000 & 1.0000000 & 1.0000000 & 1.0000000 \\
\hline 1.0000000 & 1.0000000 & 1.0000000 & 1.0000000 & 1.0000000 & 1.0000000 & 1.0000000 & 1.0000000 & 1.0000000 & 1.0000000 \\
\hline 1.0000000 & 1.0000000 & 1.0000000 & 1.0000000 & 1.0000000 & 1.0000000 & 1.0000000 & .0000000 & & \\
\hline .0000000 & .0000000 & .0000000 & .0000000 & .0000000 & .0000000 & .0000000 & .0000000 & .0000000 & .0000000 \\
\hline .0000000 & .0000000 & .0000000 & .0000000 & .0000000 & .0000000 & .0000000 & .0000000 & .0000000 & .0000000 \\
\hline .0000000 & .0000000 & .0000000 & .0000000 & .0000000 & .0000000 & .0000000 & .0000000 & .0000000 & .0000000 \\
\hline .0000000 & .0000000 & .0000000 & .0000000 & .0000000 & .0000000 & .0000000 & .0000000 & .0000000 & .0000000 \\
\hline .0000000 & .0000000 & .0000000 & .0000000 & .0000000 & .0000000 & .0000000 & .0000000 & .0000000 & .0000000 \\
\hline .0000000 & .0000000 & .0000000 & .0000000 & .0000000 & .0000000 & .0000000 & .0000000 & & \\
\hline
\end{tabular}

Initial microbial mass:

\begin{tabular}{|c|c|c|c|c|c|c|c|c|c|}
\hline dlation & 1 & & & & & & & & \\
\hline $.000 E+00$ & $.000 E+00$ & $.000 E+00$ & $.000 E+00$ & $.000 \mathrm{E}+00$ & $.000 \mathrm{E}+00$ & $.000 \mathrm{E}+00$ & $.000 E+00$ & $.000 \mathrm{E}+00$ & $.000 \mathrm{E}+00$ \\
\hline $.000 E+00$ & $.000 E+00$ & $.000 \mathrm{E}+00$ & $.000 E+00$ & $.000 E+00$ & $.000 \mathrm{E}+00$ & $.000 E+00$ & $.000 E+00$ & $.000 \mathrm{E}+00$ & $.000 \mathrm{E}+00$ \\
\hline $.000 E+00$ & $.000 E+00$ & $.000 E+00$ & $.000 E+00$ & $.000 E+00$ & $.000 E+00$ & $.000 E+00$ & $.000 E+00$ & $.000 \mathrm{E}+00$ & $.000 E+00$ \\
\hline $.000 E+00$ & $.000 \mathrm{E}+00$ & $.000 E+00$ & $.000 E+00$ & $.000 E+00$ & $.000 \mathrm{E}+00$ & $.000 \mathrm{E}+00$ & $.000 E+00$ & $.000 \mathrm{E}+00$ & $.000 \mathrm{E}+00$ \\
\hline $.000 \mathrm{E}+00$ & $.000 \mathrm{E}+00$ & $.000 E+00$ & $.000 E+00$ & $.000 E+00$ & $.000 \mathrm{E}+00$ & $.000 \mathrm{E}+00$ & $.000 \mathrm{E}+00$ & $.000 \mathrm{E}+00$ & $.000 \mathrm{E}+00$ \\
\hline $.000 \mathrm{E}+00$ & $.000 \mathrm{E}+00$ & $.000 E+00$ & $.000 \mathrm{E}+00$ & $.000 \mathrm{E}+00$ & $.000 \mathrm{E}+00$ & $.000 \mathrm{E}+00$ & $.000 \mathrm{E}+00$ & & \\
\hline $.000 E+00$ & $.820 E+00$ & $.820 \mathrm{E}+00$ & $.820 \mathrm{E}+00$ & $.820 \mathrm{E}+00$ & $.820 \mathrm{E}+00$ & $.820 \mathrm{E}+00$ & $.820 E+00$ & $.820 E+00$ & $.820 \mathrm{E}+00$ \\
\hline $.820 \mathrm{E}+00$ & $.820 E+00$ & $.820 \mathrm{E}+00$ & $.820 \mathrm{E}+00$ & $.820 \mathrm{E}+00$ & $.820 \mathrm{E}+00$ & $.820 E+00$ & $.820 \mathrm{E}+00$ & $.820 E+00$ & $.820 \mathrm{E}+00$ \\
\hline $.820 \mathrm{E}+00$ & $.820 E+00$ & $.820 E+00$ & $.820 E+00$ & $.820 E+00$ & $.820 E+00$ & $.820 \mathrm{E}+00$ & $.820 E+00$ & $.820 E+00$ & $.820 \mathrm{E}+00$ \\
\hline$E+00$ & $.820 \mathrm{E}+00$ & $E+00$ & $E+00$ & $E+00$ & $E+00$ & $.820 \mathrm{E}+00$ & $O E+00$ & $.820 \mathrm{E}+00$ & $.820 E+00$ \\
\hline+00 & $.820 \mathrm{E}+00$ & .820 & +00 & +00 & +00 & .82 & +00 & $E+00$ & $\mathrm{E}+00$ \\
\hline+00 & $.820 \mathrm{E}+00$ & $.820 E+00$ & $.820 E+00$ & $.820 \mathrm{E}+00$ & $.820 E+00$ & $.820 \mathrm{E}$ & $E+00$ & & \\
\hline .000 & $.000 E+00$ & $.000 E+00$ & $.000 E+00$ & $.000 E+00$ & $.000 \mathrm{E}$ & $8+00$ & $E+00$ & $0 E+00$ & $E+00$ \\
\hline$+\infty 0$ & $.000 \mathrm{E}+00$ & $E+00$ & $8+00$ & $8+00$ & +00 & & $E+00$ & $O E+00$ & $E+00$ \\
\hline+00 & $.000 E+00$ & $E+00$ & +00 & $8+00$ & +00 & & & $O E+0 O$ & $E+00$ \\
\hline 00 & +00 & .00 & .00 & .0 & & & .00 & 100 & $D E+00$ \\
\hline+00 & $\mathrm{E}+00$ & 800 & $+\infty 0$ & +00 & $+\infty 0$ & .00 & $+\infty$ & $0 E+00$ & $E+00$ \\
\hline $.000 E+00$ & & & & & & & & & \\
\hline ion & 2 & & & & & & & & \\
\hline & & & $.000 E+00$ & $.000 E+00$ & $.000 \mathrm{E}+00$ & & & $.000 E+00$ & $.000 \mathrm{E}+00$ \\
\hline 00 & .00 & .00 & & & & & & & +00 \\
\hline+00 & +00 & $8+00$ & +00 & .00 & .00 & & $8+00$ & & $\mathrm{DE}+00$ \\
\hline$E+00$ & & +00 & +00 & +00 & .00 & .00 & $E+00$ & $.000 \mathrm{E}+00$ & $O E+0 O$ \\
\hline & $.000 \mathrm{E}+00$ & $.000 \mathrm{E}+00$ & $E+00$ & $.000 \mathrm{E}+00$ & .00 & $E+00$ & $E+00$ & $.000 \mathrm{E}+00$ & $.000 E+00$ \\
\hline & .00 & & & & & & $E+00$ & & \\
\hline & & & & .21 & & & & & \\
\hline .210 & $.210 E+00$ & $.210 \mathrm{I}$ & .210 & .210 & .210 & .210 & $.210 \mathrm{E}+00$ & +00 & $.210 \mathrm{E}+00$ \\
\hline $.210 E+00$ & $.210 E+00$ & $.210 \mathrm{E}+00$ & $.210 \mathrm{E}+00$ & $.210 \mathrm{E}+00$ & .210 & $.210 \mathrm{E}+$ & $.210 \mathrm{E}+00$ & $.210 \mathrm{E}+00$ & $.210 E+00$ \\
\hline $.210 \mathrm{E}+00$ & $.210 \mathrm{E}+00$ & $.210 \mathrm{E}+00$ & $.210 \mathrm{E}+00$ & $.210 \mathrm{E}+00$ & $.210 \mathrm{E}+00$ & $.210 \mathrm{E}+00$ & $.210 E+00$ & $.210 \mathrm{E}+00$ & $.210 \mathrm{E}+00$ \\
\hline $.210 \mathrm{E}+00$ & $.210 E+00$ & & $.210 E+00$ & $.210 E+00$ & $.210 E+00$ & $.210 E+00$ & $.210 E+00$ & $.210 E+00$ & $.210 \mathrm{E}+00$ \\
\hline & .210 & & & & & & & & \\
\hline & .0001 & & $.000 \mathrm{E}$ & & $+\infty 0$ & & $+\infty 0$ & .00 & \\
\hline .000 & .0001 & $.000 \mathrm{E}+00$ & $.000 E+00$ & $.000 E+00$ & $.000 \mathrm{E}+00$ & $.000 \mathrm{E}+00$ & $.000 \mathrm{E}+00$ & $8+\infty 0$ & $.000 \mathrm{E}+00$ \\
\hline $.000 E+00$ & $.000 \mathrm{E}$ & $.000 E+00$ & $.000 E+00$ & $.000 E+00$ & $.000 \mathrm{E}+00$ & $.000 E+00$ & $.000 \mathrm{E}+00$ & $.000 E+00$ & $.000 \mathrm{E}+00$ \\
\hline $.000 E+00$ & $.000 E+00$ & $.000 E+00$ & $.000 E+00$ & $.000 E+00$ & $.000 E+00$ & $.000 E+00$ & $.000 \mathrm{E}+00$ & $.000 E+00$ & $.000 E+00$ \\
\hline $.000 E+00$ & $.000 E+00$ & $.000 \mathrm{E}+00$ & $.000 E+00$ & $.000 E+00$ & $.000 E+00$ & $.000 \mathrm{E}+00$ & $.000 E+00$ & $.000 E+00$ & $.000 \mathrm{E}+00$ \\
\hline $.000 E+00$ & $.000 E+00$ & $.000 E+00$ & $.000 E+00$ & $.000 E+00$ & $.000 E+00$ & $.000 E+00$ & $.000 \mathrm{E}+00$ & & \\
\hline
\end{tabular}

There are 2 degradation processes active
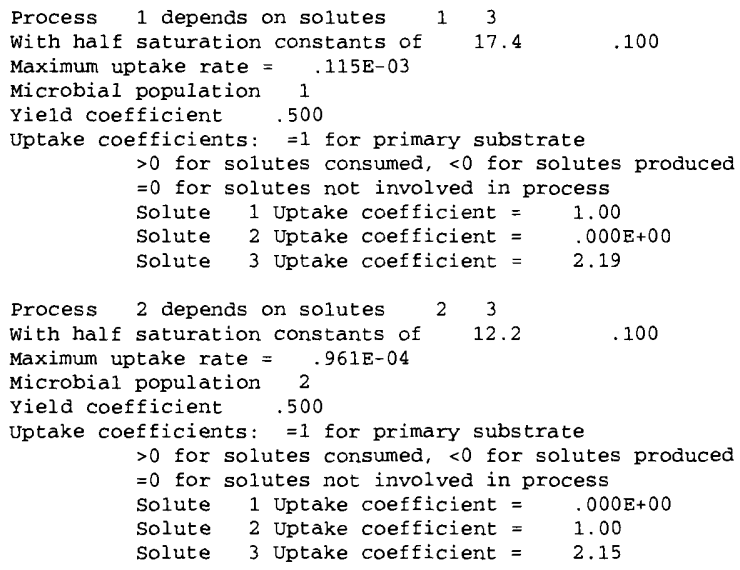

Solute

Microbe population 1:

death rate constant $\quad .116 \mathrm{E}-05$ nzinhib $=0$, zinhibfac $=.00$

Microbe population 2:

death rate constant $\quad .116 \mathrm{E}-05$ nzinhib $=0$, zinhibfac $=.00$ 


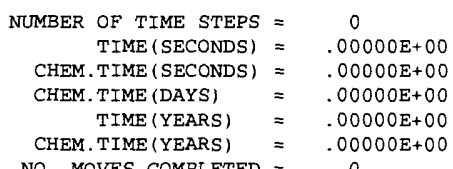

1DRAWDOWN

0 CUMULATIVE Mass BALANCE -- (IN L**3)

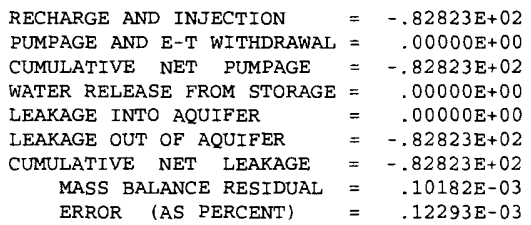

0 RATE MASS BALANCE -- (IN C.F.S.)

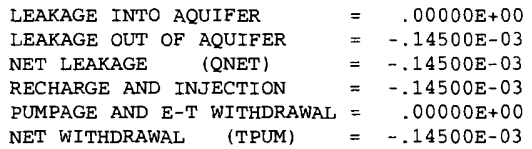

AT NODES

$\begin{array}{rrrr}.000 \mathrm{E}+00 & .000 \mathrm{E}+00 & .000 \mathrm{E}+00 & .000 \mathrm{E}+00 \\ .000 \mathrm{E}+00 & .000 \mathrm{E}+00 & .000 \mathrm{E}+00 & .000 \mathrm{E}+00 \\ .000 \mathrm{E}+00 & .000 \mathrm{E}+00 & .000 \mathrm{E}+00 & .000 \mathrm{E}+00 \\ .000 \mathrm{E}+00 & .000 \mathrm{E}+00 & .000 \mathrm{E}+00 & .000 \mathrm{E}+00 \\ .000 \mathrm{E}+00 & .000 \mathrm{E}+00 & .000 \mathrm{E}+00 & .000 \mathrm{E}+00 \\ .000 \mathrm{E}+00 & .000 \mathrm{E}+00 & .000 \mathrm{E}+00 & .000 \mathrm{E}+00 \\ .000 \mathrm{E}+00 & 1.908 \mathrm{E}-04 & 3.816 \mathrm{E}-04 & 3.816 \mathrm{E}-04 \\ 3.816 \mathrm{E}-04 & 3.816 \mathrm{E}-04 & 3.816 \mathrm{E}-04 & 3.816 \mathrm{E}-04 \\ 3.816 \mathrm{E}-04 & 3.816 \mathrm{E}-04 & 3.816 \mathrm{E}-04 & 3.816 \mathrm{E}-04 \\ 3.816 \mathrm{E}-04 & 3.816 \mathrm{E}-04 & 3.816 \mathrm{E}-04 & 3.816 \mathrm{E}-04 \\ 3.816 \mathrm{E}-04 & 3.816 \mathrm{E}-04 & 3.816 \mathrm{E}-04 & 3.816 \mathrm{E}-04 \\ 3.816 \mathrm{E}-04 & 3.816 \mathrm{E}-04 & 3.816 \mathrm{E}-04 & 3.816 \mathrm{E}-04 \\ .000 \mathrm{E}+00 & .000 \mathrm{E}+00 & .000 \mathrm{E}+00 & .000 \mathrm{E}+00 \\ .000 \mathrm{E}+00 & .000 \mathrm{E}+00 & .000 \mathrm{E}+00 & .000 \mathrm{E}+00 \\ .000 \mathrm{E}+00 & .000 \mathrm{E}+00 & .000 \mathrm{E}+00 & .000 \mathrm{E}+00 \\ .000 \mathrm{E}+00 & .000 \mathrm{E}+00 & .000 \mathrm{E}+00 & .000 \mathrm{E}+00\end{array}$

$.000=00$ $.000 \mathrm{E}+00$ $.000 E+00$ $.000 E+00$ $.000 \mathrm{E}+00$ 3. $816 \mathrm{E}-04$ $3.816 \mathrm{E}-04$ 3. $816 E-04$ 3. $816 E-04$ 3. $816 \mathrm{E}-04$ 3. $816 E-04$ $.000 E+00$ $.000 E+00$ $.000 E+00$ $.000 E+00$
$.000 E+00$ $.000 E+00$ $.000 \mathrm{E}+00$ $.000 E+00$ $.000 E+00$ $.000 \mathrm{E}+00$ 3. $816 \mathrm{E}-04$ $3.816 \mathrm{E}-04$ 3. $816 E-04$ $3.816 \mathrm{E}-04$ 3. $816 \mathrm{E}-04$ $3.816 \mathrm{E}-04$ $.000 E+00$ $.000 \mathrm{E}+00$ $000 \mathrm{E}+00$ $.000 \mathrm{E}+00$

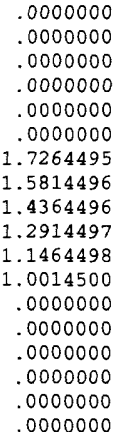

.0000000 .0000000 .0000000 .0000000 .0000000 .0000000

1. 7119495 1.5669496 1. 4219496 1.2769497 1. 1319499 .000000 0000000 .0000000 .0000000 .0000000
.0000000 .0000000 .0000000 .0000000 .0000000

1. 6974495 1.5524496

1.4074496

1. 2624497

1.1174499

0000000 .0000000 .0000000 .0000000 .0000000
.0000000 .0000000 .0000000 .0000000 .0000000

1.6829495 1.5379496 1.3929496 1.2479497 1.1029499

.0000000 .0000000 .0000000 .0000000 .0000000

$\begin{array}{rr}.000 E+00 & .000 E+00 \\ .000 E+00 & .000 E+00 \\ .000 E+00 & .000 E+00 \\ .000 E+00 & .000 E+00 \\ .000 E+00 & .000 E+00 \\ .000 E+00 & .000 E+00 \\ 3.816 E-04 & 3.816 E-04 \\ 3.816 E-04 & 3.816 E-04 \\ 3.816 E-04 & 3.816 E-04 \\ 3.816 E-04 & 3.816 E-04 \\ 3.816 E-04 & 3.816 E-04 \\ 1.908 E-04 & .000 E+00 \\ .000 E+00 & .000 E+00 \\ .000 E+00 & .000 E+00 \\ .000 E+00 & .000 E+00 \\ .000 E+00 & .000 E+00\end{array}$

$.000 E+00$ $.000 E+00$ $000 E+00$ $.000 E+00$

3. $816 \mathrm{E}-04$ 3. $816 \mathrm{E}-04$ 3. $816 \mathrm{E}-04$ $3.816 E-04$ 3. $816 E-04$

$.000 E+00$ $.000 E+00$ $.000 E+00$ $.000 \mathrm{E}+00$
$.000 E+00$ $.000 E+00$ $.000 E+00$ $.000 \mathrm{E}+00$ $.000 \mathrm{E}+00$

3. $816 \mathrm{E}-04$ $3.816 \mathrm{E}-04$ $3.816 \mathrm{E}-04$ $3.816 \mathrm{E}-04$ 3. $816 \mathrm{E}-04$

$.000 E+00$ $.000 E+00$ $.000 E+00$ $.000 E+00$ 


\begin{tabular}{|c|c|c|c|c|c|c|c|c|c|}
\hline $\begin{array}{l}.000 \mathrm{E}+00 \\
.000 \mathrm{E}+00\end{array}$ & $\begin{array}{l}.000 E+00 \\
.000 E+00\end{array}$ & $\begin{array}{l}.000 E+00 \\
.000 E+00\end{array}$ & $\begin{array}{l}.000 \mathrm{E}+00 \\
.000 \mathrm{E}+00\end{array}$ & $\begin{array}{l}.000 E+00 \\
.000 E+00\end{array}$ & $\begin{array}{l}.000 \mathrm{E}+00 \\
.000 \mathrm{E}+00\end{array}$ & $\begin{array}{l}.000 E+00 \\
.000 E+00\end{array}$ & $\begin{array}{l}.000 \mathrm{E}+00 \\
.000 \mathrm{E}+00\end{array}$ & $.000 \mathrm{E}+00$ & $.000 \mathrm{E}+00$ \\
\hline \multicolumn{10}{|c|}{ AT NODES } \\
\hline $.000 \mathrm{E}+00$ & $.000 \mathrm{E}+00$ & $.000 E+00$ & $.000 \mathrm{E}+00$ & $.000 E+00$ & $.000 E+00$ & $.000 E+00$ & $.000 \mathrm{E}+00$ & $.000 E+00$ & $.000 E+00$ \\
\hline $.000 \mathrm{E}+00$ & $.000 \mathrm{E}+00$ & $.000 E+00$ & $.000 \mathrm{E}+00$ & $.000 E+00$ & $.000 E+00$ & $.000 E+00$ & $.000 E+00$ & $.000 E+00$ & $.000 E+00$ \\
\hline $.000 E+00$ & $.000 E+00$ & $.000 E+00$ & $.000 E+00$ & $.000 \mathrm{E}+00$ & $.000 E+00$ & $.000 E+00$ & $.000 \mathrm{E}+00$ & $.000 E+00$ & $.000 E+00$ \\
\hline $.000 \mathrm{E}+00$ & $.000 E+00$ & $.000 E+00$ & $.000 E+00$ & $.000 E+00$ & $.000 \mathrm{E}+00$ & $.000 E+00$ & $.000 \mathrm{E}+00$ & $.000 E+00$ & $.000 E+00$ \\
\hline $.000 \mathrm{E}+00$ & $.000 E+00$ & $.000 E+00$ & $.000 E+00$ & $.000 E+00$ & $.000 E+00$ & $.000 E+00$ & $.000 \mathrm{E}+00$ & $.000 E+00$ & $.000 \mathrm{E}+00$ \\
\hline $.000 E+00$ & $.000 E+00$ & $.000 \mathrm{E}+00$ & $.000 E+00$ & $.000 E+00$ & $.000 \mathrm{E}+00$ & $.000 E+00$ & $.000 \mathrm{E}+00$ & & \\
\hline $.000 \mathrm{E}+00$ & $.000 E+00$ & $.000 \mathrm{E}+00$ & $.000 E+00$ & $.000 E+00$ & $.000 \mathrm{E}+00$ & $.000 E+00$ & $.000 E+00$ & $.000 \mathrm{E}+00$ & $.000 E+00$ \\
\hline $.000 E+00$ & $.000 \mathrm{E}+00$ & $.000 E+00$ & $.000 \mathrm{E}+00$ & $.000 \mathrm{E}+00$ & $.000 \mathrm{E}+00$ & $.000 E+00$ & $.000 \mathrm{E}+00$ & $.000 \mathrm{E}+00$ & $.000 \mathrm{E}+00$ \\
\hline $.000 \mathrm{E}+00$ & $.000 E+00$ & $.000 E+00$ & $.000 \mathrm{E}+00$ & $.000 E+00$ & $.000 \mathrm{E}+00$ & $.000 E+00$ & $.000 \mathrm{E}+00$ & $.000 \mathrm{E}+00$ & $.000 E+00$ \\
\hline $.000 \mathrm{E}+00$ & $.000 E+00$ & $.000 E+00$ & $.000 E+00$ & $.000 \mathrm{E}+00$ & $.000 \mathrm{E}+00$ & $.000 E+00$ & $.000 \mathrm{E}+00$ & $.000 E+00$ & $.000 \mathrm{E}+00$ \\
\hline $.000 \mathrm{E}+00$ & $.000 \mathrm{E}+00$ & $.000 \mathrm{E}+00$ & $.000 \mathrm{E}+00$ & $.000 \mathrm{E}+00$ & $.000 E+00$ & $.000 \mathrm{E}+00$ & $.000 E+00$ & $.000 E+00$ & $.000 E+00$ \\
\hline $.000 \mathrm{E}+00$ & $.000 E+00$ & $.000 E+00$ & $.000 \mathrm{E}+00$ & $.000 \mathrm{E}+00$ & $.000 E+00$ & $.000 E+00$ & $.000 E+00$ & & \\
\hline $.000 E+00$ & $.000 E+00$ & $.000 E+00$ & $.000 E+00$ & $.000 E+00$ & $.000 E+00$ & $.000 E+00$ & $.000 E+00$ & $.000 E+00$ & $.000 E+00$ \\
\hline $.000 \mathrm{E}+00$ & $.000 \mathrm{E}+00$ & $.000 E+00$ & $.000 E+00$ & $.000 \mathrm{E}+00$ & $.000 E+00$ & $.000 \mathrm{E}+00$ & $.000 E+00$ & $.000 E+00$ & $.000 E+00$ \\
\hline $.000 \mathrm{E}+00$ & $.000 \mathrm{E}+00$ & $.000 E+00$ & $.000 \mathrm{E}+00$ & $.000 \mathrm{E}+00$ & $.000 \mathrm{E}+00$ & $.000 E+00$ & $.000 \mathrm{E}+00$ & $.000 \mathrm{E}+00$ & $.000 \mathrm{E}+00$ \\
\hline $.000 \mathrm{E}+00$ & $.000 E+00$ & $.000 E+00$ & $.000 \mathrm{E}+00$ & $.000 E+00$ & $.000 E+00$ & $.000 E+00$ & $.000 \mathrm{E}+00$ & $.000 \mathrm{E}+00$ & $.000 \mathrm{E}+00$ \\
\hline $.000 \mathrm{E}+00$ & $.000 \mathrm{E}+00$ & $.000 E+00$ & $.000 \mathrm{E}+00$ & $.000 \mathrm{E}+00$ & $.000 \mathrm{E}+00$ & $.000 E+00$ & $.000 \mathrm{E}+00$ & $.000 E+00$ & $.000 E+00$ \\
\hline
\end{tabular}

0 MAXIMUM FLUID VELOCITIES: X-VEL $=3.82 \mathrm{E}-04 \quad \mathrm{Y}$-VEL $=1.00 \mathrm{E}-10$

0 TMV (MAX. INJ.) $=2620.7$

TIMV (CELDIS) $=262.07$

O TIMV $=2.62 \mathrm{E}+02 \quad$ NTIMV $=2179 \quad$ NMOV $=2180$

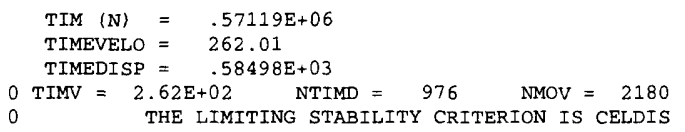

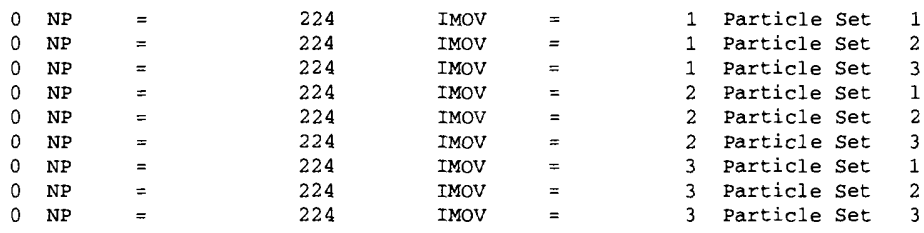

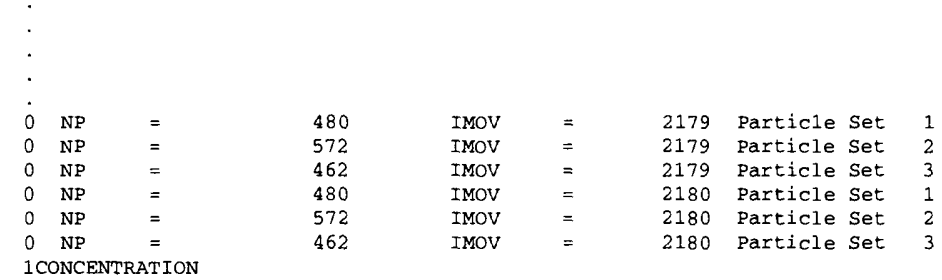

1CONCENTRATION

$\begin{array}{rlr}\text { NUMBER OF TIME STEPS } & = & 1 \\ \text { DELTA T } & = & .57119 \mathrm{E}+06 \\ \text { TIME (SECONDS) } & = & .57119 \mathrm{E}+06 \\ \text { CHEM. TIME (SECONDS) } & = & .57118 \mathrm{E}+06 \\ \text { CHEM.TIME (DAYS) } & = & .66108 \mathrm{E}+01 \\ \text { TIME (YEARS) } & = & .18100 \mathrm{E}-01 \\ \text { CHEM.TIME (YEARS) } & = & .18099 \mathrm{E}-01\end{array}$

CHEM TTME (YEARS) $=18099 \mathrm{E}-01$

NO. MOVES COMPLETED $=2180$

Solute 1

CHEMICAL MASS BALANCE

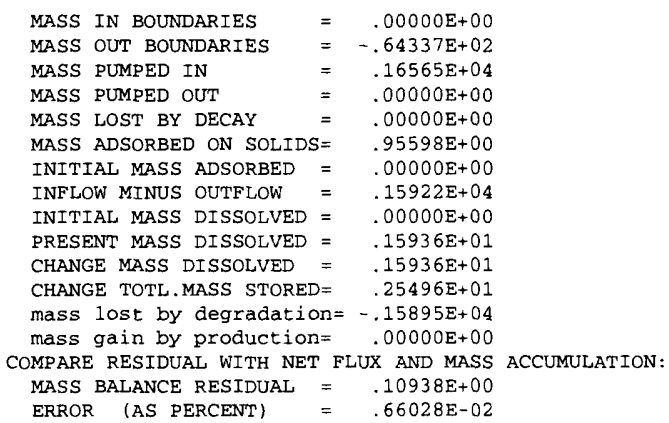


CHEMICAL MASS BALANCE

\begin{tabular}{|c|c|c|}
\hline MASS IN BOUNDARIES & $.00000 \mathrm{E}+00$ & \\
\hline MASS OUT BOUNDARIES & $-.15532 \mathrm{E}+03$ & \\
\hline MASS PUMPED IN & $.16565 \mathrm{E}+04$ & \\
\hline MASS PUMPED OUT & $.00000 \mathrm{E}+00$ & \\
\hline MASS LOST BY DECAY & $.00000 \mathrm{E}+00$ & \\
\hline MASS ADSORBED ON SOLIDS & $.54583 \mathrm{E}+00$ & \\
\hline INITIAL MASS ADSORBED & $.00000 \mathrm{E}+00$ & \\
\hline INFLOW MINUS OUTFLOW & $.15012 \mathrm{E}+04$ & \\
\hline INITIAL MASS DISSOLVED & $.00000 \mathrm{E}+00$ & \\
\hline PRESENT MASS DISSOLVED & $.13599 \mathrm{E}+01$ & \\
\hline CHANGE MASS DISSOLVED & $.13599 \mathrm{E}+01$ & \\
\hline CHANGE TOTL.MASS STORED & $.19058 \mathrm{E}+01$ & \\
\hline mass lost by degradatio & $-.14980 \mathrm{E}+04$ & \\
\hline mass gain by production & $.00000 \mathrm{E}+00$ & \\
\hline OMPARE RESIDUAL WITH NET & T FLUX AND MASS & S ACCUMULATION: \\
\hline MASS BALANCE RESIDUAL & $=\quad .12701 \mathrm{E}+01$ & \\
\hline ERROR (AS PERCENT) & $.76677 \mathrm{E}-01$ & \\
\hline
\end{tabular}
solute 3

CHEMICAL MASS BALANCE

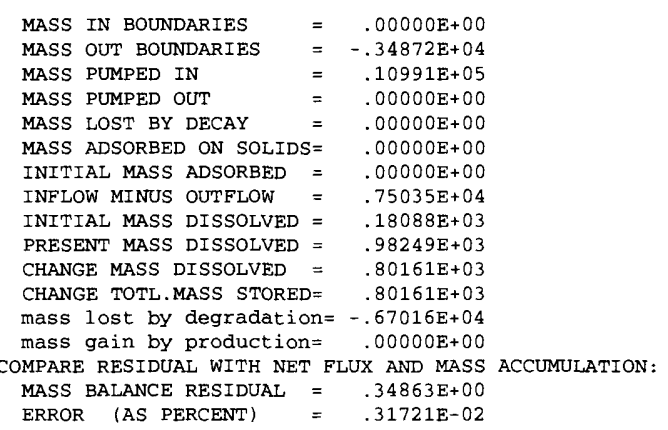

